SB
405
$i 16$
$i 922$

A $=800$

$20+1 \times y^{4}$

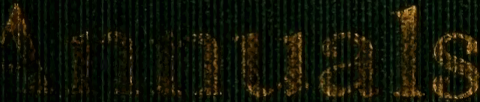

TH.

"L.HWTHW HOOOK"

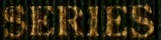




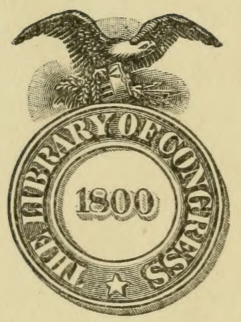

Class

Book

Copyrighth $\mathrm{N}^{\circ}$.

COPYRIGHT DEPOSTT. 







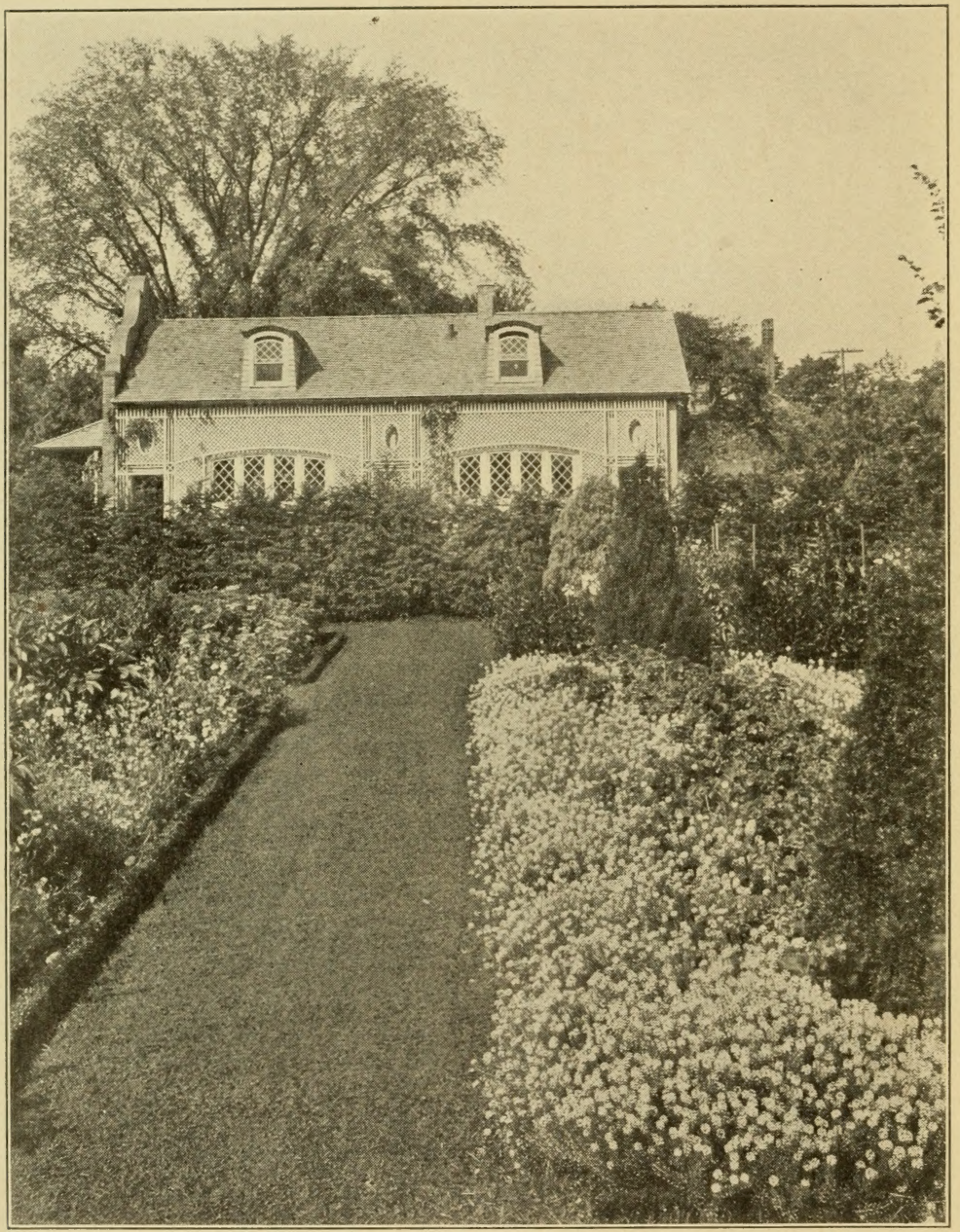

THE CHARM OF ANNUALS IN THE GARDEN

Fig. 1.-An eminently successful utilization of Sweet Alyssum (see p. 31) in a delightfully planned border. There is nothing better with which to edge beds containing shrubs and herbaceous flowers of all sorts. Moreover, the dainty, vivacious blossoms are in evidence the entire Summer through-and from a single planting, if the withered blooms are frequently removed. 


\title{
A Little Book
} of

\section{Annuals}

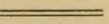

\author{
By \\ ALFRED C. HOTTES \\ DEPARTMENT OF HORTICUITURE \\ OHIO STATE UNIVERSITY
}
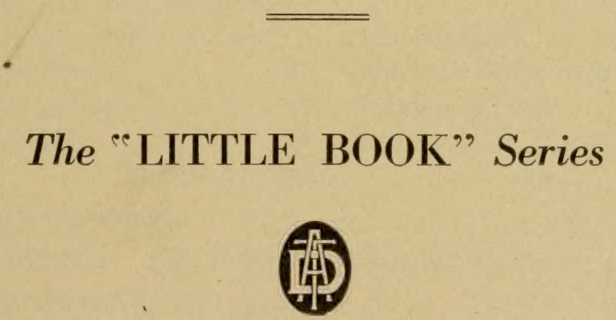

NEW YORK, N. Y.

The A. T. De La Mare Company, Inc. 


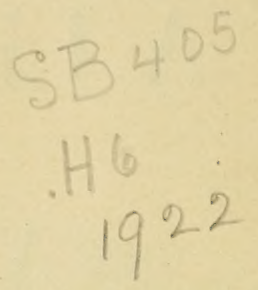

COPYRIGHT, 1922, BY

THE A. T. DE LA MARE COMPANY, INC.

NEW YORK. N. Y.

SEP $-5 \cdot 1922$

(C) $A 681649$ 


\section{CONTENTS}

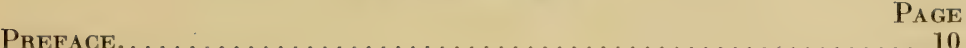

The Use of Annuals. . . . . . . . . . . . . . . . . . . 11

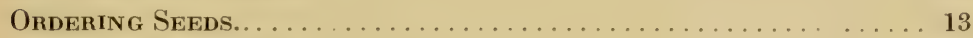

Glasses of Annuals... . . . . . . . . . . . . . . . . . . 14

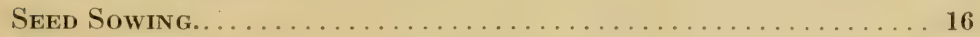

Transplanting............................... 19

Pinching. . . . . . . . . . . . . . . . . . . . . . 21

The Hoe $v s$. The Hose. . . . . . . . . . . . . . . . . . . 21

Watering $v s$. Sprinkling. . . . . . . . . . . . . . . 22

Annuals and Shade. . . . . . . . . . . . . . . . . . . 23

Fall Sowing and Self-sown Annuals. . . . . . . . . . . . . . 23

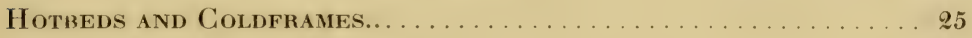

Annual Flowers and Their Uses. . . . . . . . . . . . . 27

These flowers please us with For poor soil............29

their fragrance.........27 For temporary hedges.......28

Flowers for picking .......27 Edging annuals..........28

Foliage annuals.........28 For hot, dry places........29

For moist places.........28

A Chain of Ten Links... . . . . . . . . . . . . . . . . . 29

Annuals of Merit. (See index for particular sorts) . . . . . . . . 31

Ornamental Grasses........................... 95

Evertastings... . . . . . . . . . . . . . . . . . . . 97

Decorative Seed Pods . . . . . . . . . . . . . . . . . . . . 103

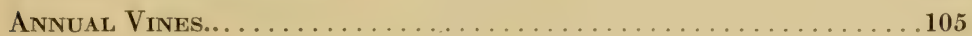

Index to Plant Names. . . . . . . . . . . . . . . . . . . . 111

Tabular Gultural Index . . . . . . . . . . . . . . . . . . . 113 


\section{LIST OF ILLUSTRATIONS}

Fig. 1-The charm of annuals in the garden (Sweet Alyssum)

Frontispiece

PAGE

Fig. 2-Two suggested annual horder planting plans........... 10

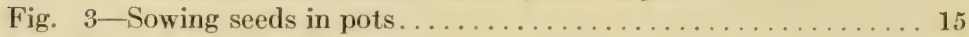

Fig. 4-A flat for seed sowing ................. 17

Fig. 5 - $\mathrm{A}$ handy frame for marking out rows in a seed flat . . . . 17

Fig. 6-Small pots for seedlings hard to transplant . . . . . . . . . 18

Fig. 7-Seedlings of some common annuals... . . . . . . . . 19

Fig. 8-Good and poor seedlings contrasted.............. 20

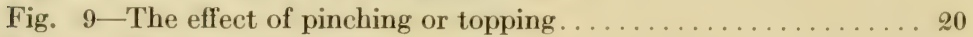

Fig. 10 -Watering fine seeds or seedlings................ 21

Fig. 11-A plan for a corner planting of yellow and gold.......... 22

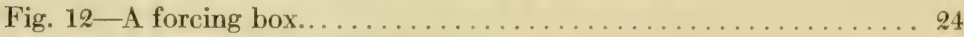

Fig. 13-Section of a hotbed frame................... 25

Fig. 14-Four suggestions for arrangements of annuals... . . . . . 30

Fig. 15-Ageratum, Blue-eyed African Daisy, Agemone and Browallia. 32

Fig. 16-Prince's Feather, Balsam and Calendula ............. . 34

Fig. 17-Coreopsis Drummondii and C. tinctoria............. 37

Fig. 18-The showy Castor Bean plant.................. 38

Fig. 19-Cockscomb, Candytuft, and Woolflower........... 40

Fig. 20-Sweet Sultans and Corn Flowers, or Bachelor's Buttons.. . . . . 42

Fig. 21-Types of China Asters..................... 43

Fig. 22-China Asters effectively placed along a garden walk . . . . . . 44

Fig. 23-Clarkia and the Annual Chrysanthemum ............47

Fig. 24-How to tie plants to stakes; also Giant Spider Flower, and Cosmos............................. 49

Fig. 25-Blue Lace Flower, Four o'Clock and Gaillardia. . . . . . . . . 51

Fig. 26-Datura, Flora's Paint Brush, African Orange Daisy, and Cal-

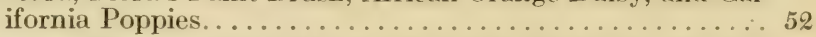

Fig. 27-Scarlet Flax, Godetia, Rocket-flowered Larkspur, Hunnemannia, and Lavatera..................... 56

Fig. 28-Gypsophila, a dainty, almost indispensable flower. . . . . . . 57

Fig. 29-An attractive edging of the dwarf, upright Lobelia... . . . . . 60

Fig. 30-Lupine spikes make dainty cut flowers. . . . . . . . . . . 61 61

Fig. 31 - Three kinds of Marigolds.................... 61

Fig. 32-Mignonette- "its sweetness wins all hearts"..........63 
Fig. 33-Leaves of the Sensitive Plant................. 64

Fig. 34-The Monkey Flower, bizarre, but well worth growing. . . . . 64 Fig. 35-The dwarf Morning Glory .................... 65 Fig. 36-Ornamental Tobacco in the daytime with flowers closed . . . . 66

Fig. 37-The blue Nigella flowers with their lacy collars......... 68 Fig. 38- $\Lambda$ glorious mass of Pansies and Petunias.............. 70 Fig. 39-Phlox Drummondii, Pentstemon and Star Phlox......... 74 Fig. 40-The Opium Poppy, Physalis and Double China Pinks..... . 76 Fig. 41-The graceful, silky petaled Shirley Poppies............. 77 Fig. 42-Salpiglossis, Portulaca and Scabiosa................ 78 Fig. 43-Stock, Sunflowers, Schizanthus and Snapdragon......... 82 Fig. 44-An excellent example of the successful use of Kochia....... 83 Fig. 45-Diagram comparing old and new Sweet Pea planting methods. 87 Fig. 46-Zinnias, Torenia, Verbenas, Orchid-flowering Sweet Peas and Virginian Stock.......................... 90

Fig. 47 -Some of the more popular ornamental grasses.......... 96 Fig. 48-Strawflowers.............................. 100 Fig. 49-The amusing Canary Bird Vine................... 104 Fig. 50-Nasturtiums provide abundant flowers.............. 104 Fig. 51-Cobæa, Morning Glory, the Cypress Vine, the Balsam Apple, and Dipper Gourds.......................... 106

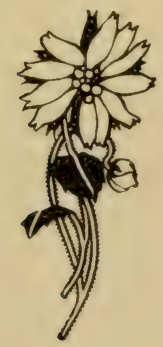




\section{PREFACE}

THIS little book of annuals has been written for the increasing throng 1 of amateurs who grow flowers for the love of them. It is meant to be a guide through the season of annual bloom. It is hoped that it will open some doors to greater success and that it may introduce you to some new friends. Do not shun one of these new acquaintances because its name is long-no doubt your name also is long, difficult to pronounce and with far less meaning.

And if you pause before planting because of lack of experience, remember that love of flowers finds a way as quickly as knowledge. There are friends on every hand ready and anxious to advise you. Advice from a flower lover is as free as the rain and the sunshine.

Credit should be given to some of my friends who have criticized and helped in many ways, and to the hopeless array of catalogs now upon my desk - all of whom and which have contributed to this brief account of the vast group of alluring annual flowers.

Alfred C. Hottes.

Columbus, O., February 14, 1929.

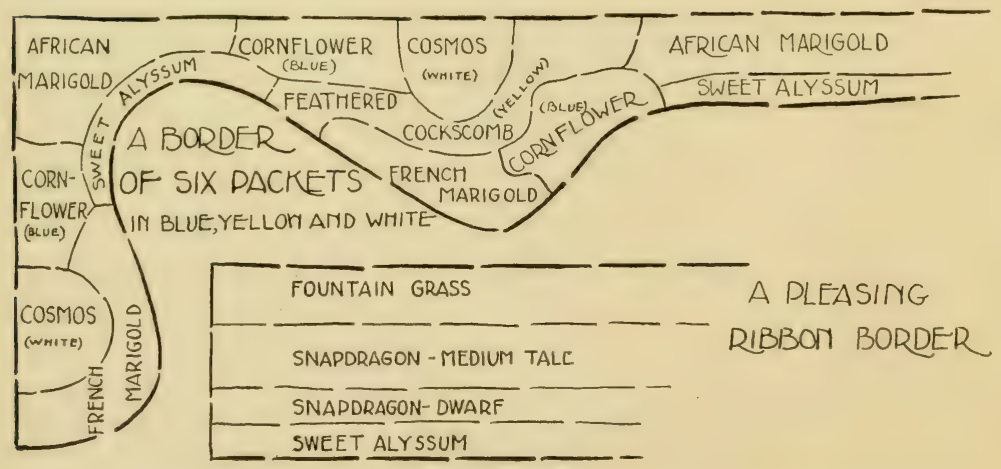

Fig. 2.-Two suggested annual border planting plans. Other suggestions for the use of different annuals in combination will be found on pages 22 and 30. 


\section{THE USE OF ANNUALS}

A MONG the choicest flowers scattered over the earth are some A whose lives are short. They sprout from seed, grow, flower produce seed in their turn-and then die, all within the limits of a single season of our gardening year. These are the annuals. The very aim of their existence is seed production, and if it were not for our watchful care, many of the sorts would exhaust themselves early in the season. The more flowers we pluck the more they bloom. This is the great charm of annuals. They may always be depended upon to give a splendid showing the year they are sown.

Each of you who reads these words has a definite object in doing so. Perhaps you are expert in their care and familiar with their habits and read because the love of gardens prompts you to spend one-half the year rearing the flowers and the other half reading about them. Perhaps you have a new house and have resolved to make it a homelike place where flowers add their gentle touch. Or again, perhaps you have grown some of the annuals and are anxious to grow others because you like color, fragrance and form. There is nothing more fascinating than growing some different flowers each year.

For you who are just beginning your garden enthusiasm we must frankly write that you are plunging into dangerous waters. The interest in gardening is absorbing, it will draw you into many difficulties. You will neglect some of your work and the less enthusiastic gardeners of your family will sometimes criticize your personal appearance. They will often hint that you never rest. They will think that you are trying to be superior when you repeat the botanical names. At the same time do not fear, for no matter what they say of you, you can depend upon their accepting the flowers after you have grown them.

The true lovers of annuals are those whose homes are surrounded by the permanent plantings of shrubs and perennial flowers. They realize that some spot will need a little fixing. They are wise enough to know that every particular season will be severe for some sort of plant and that if Spring finds them without a few packets of annual seeds on hand, they will regret their lack of foresight. Let the annuals serve as understudies for the shrubs and perennials, so that should they sicken and die the annuals can be substituted. 
Those who rent their homes feel as keen a need for flowers as those more permanently established. When the income is limited, they often feel that money should not be spent upon the more lasting, slower developing shrubbery and perennials. A few dollars spent on annuals will bring joy to these families and when they have to move there will be fewer regrets. So it is also with those persons who have modest country homes and cottages at the lakeside. How much a few flowers add to the livability of these houses!

How many city homes are without gardens in spite of the opportunities offered by windowsills and porches. Hanging baskets, pots of flowers and porch boxes all demand annuals. Have vines to trail, climb, shade and frame views. Have annuals in boxes and pots to convert the porch into a veritable garden. Perhaps you have ridden in the elevated trains in New York City and noticed the Geraniums in tin cans, the vines upon fire escapes. They are the expression of a universal human hunger for flowers.

The hearts of children respond to flowers, especially when the parents encourage the interest. They love the bright colors. They enjoy planting the seeds, watching the plants grow, seeing them produce the gay flowers. Every home yard should afford some little space where the boys and girls may have a garden of their own. Instill in children this love of beauty, this need for careful attention to details, and they will not outgrow it. Our whole country will be embellished with flowers in the future. The desert and Arctic regions produce their flowers, their climatic obstacles notwithstanding; yet all too many homes are without flowers in states where rain falls abundantly and the sun tempers the climate.

Dr. L. C. Corbett once wrote:

"Plants are the missionaries of Nature constantly at work attempting to cover some ugly scar which civilized man has made in his struggle to wrest from the earth the living which he claims she owes him. If you will but give Nature the suggestion of your wishes in the form of a few choice seeds she will paint for you the rich shades of the Pansy or the Phlox; she will carpet your floor with a velvet rug of green and strew upon its surface in bold contrast the golden disks of the Dandelion or the bright, saucy faces of the Crocus. She will drape your walls with a festoon of green and hide therein rich gems of purple, of crimson, and of white; and, if you ask it, she will screen one apartment from another with barriers of green which may or may not carry bright floral gems." 


\section{ORDERING SEEDS}

GREQUENTLY the question is asked. "Why are my flowers so small, so single or of such a poor habit of growth ?" Sometimes this question can be truthfully answered by saying that the person has purchased inferior seed. Hence the admonition: Buy the best seed obtainable.

Some of the largest and most fully double flowers produce but little seed. Seed of the best Pansies, Sweet Peas, China Asters and Petunias is always more expensive than the seed of ordinary mixed sorts. Newer varieties are usually more expensive because each seedsman has but a limited quantity of their seed.

When browsing over a catalog it is better to mark a packet of each of several good colors of the flowers you want than several packets of the mixed varieties. The clear colors are usually better selected. Those who like mixture should sow together the colors they prefer.

Whenever seed is offered in bulk for a few cents more than a packet would cost, remember that you get a larger quantity by buying one-sixteenth ounce than is usually sold in a packet of presumably the same weight.

Many persons are led to buy seeds by the beautiful picture on the envelope and neglect to think of the seed within. Generally it is best to patronize seedsmen who have regular stores for selling seeds, or those who issue catalogs. Grocers and ten-cent stores usually are not seedsmen. They cannot advise you what to buy nor are they fitted to handle the freshest seeds of the better varieties.

Shall you order seeds of novelties? The attractive first few pages of many catalogs display the newer sorts of flowers. Remember that these flowers have not been tested widely, that they may not be adapted to your locality, that being but recently produced the seeds do not always come true-yes, remember all these things, and then if you are tempted to try them, do so. You may be surprised one way or another. They may prove a joy because of their rarenessand if they are not wholly successful, bear in mind that curiosity costs something. Yet no packet of seed cataloged ever cost a fortune, 


\section{CLASSES OF ANNUALS}

WHOEVER would succeed with annuals should know whether they will tolerate being sown in cold soil or whether it is necessary to sow them only when the soil is warm.

There are three sorts of annuals:

Hardy Annuals. The word "hardy" applied to plants has a different meaning than "hearty," although some persons speak incorrectly of "hardy Castor Beans," meaning that they are strong growing. Hardy means that the annual will stand the cold and may be sown with perfect safety either in the late Fall or early Spring. Such annuals are usually sown directly in the beds and transplanted farther apart as they need more space. No strict lists can be given of hardy annuals, for hardiness is a variable quality. Some annuals are hardy in sandy ground; others are hardy because the snow covers the soil and protects them over Winter; while in some parts of the United States an entirely different list would be necessary because the cold weather is of short duration. See page 23 for a discussion of Fallsowing and self-sowing annuals.

Tender Annuals. Tender annuals are those which can stand no cold either in Spring or Fall. They must never be sown out in cold soil but only when the trees are in leaf. When sown in March in a warm window or hotbed, they will bloom earlier than otherwise.

The following annuals are generally considered tender. (Those marked with a * sometimes self-sow but are best treated as though tender):

*Ageratum (Floss Flower)

*Browallia (Amethyst)

Cianary Cremper

Chrysanthemum, Annual

*Cleone (Giant Spider Plant)

COBEA

Didiscus

Dolichos (Hyacinth Bean)

Euphorbia heterophylla (Annual Poinsettia)

Gourd

*Impatiens (Balsam)

Linaria (Toadflax)
Malope (Annual Mallow)

Mesembryanthemum (Ice Plant, or Fig Marigold)

Mignonette

Mrmosa (Sensitive Plant)

Mimulus (Monkey Flower, or Musk Plant)

Momondica (Balsam Apple)

Morning Glory, DwarF

Nasturtium

Nemophila

*Nicotiana

Phacelia

Phaseolus (Scarlet Runner Bean) 


\section{Tender Annuals, continued}

Rhodanthe (Swan River Ever- Stock lasting)

Ricinus (Gastor Bean)

Salvia (Scarlet Sage)

Salpiglossis (Painted Tongue)

Schizanthus (Butterfly Flower)

TAgetes signata pumila (Mexican Marigold)

Torenia (Wishbone Flower)

VERBENA

ZEA (Variegated Corn)

Half-hardy Annuals. This is a convenient class in which are placed principally those annuals which benefit by being given an earlier start than they would receive if sown directly in the open ground. Usually it is not safe to sow them outside until danger from frost is passed. The growing season of northern United States is a trifle short to permit these sorts to bloom early. Usually they require warmth during their early growth. Sow them, therefore, in the hotbed or in boxes in a sunny window in March.

The following are half-hardy annuals:

Acrochinium

Аммовгum (Winged Everlasting)

BAsket Flower (Centaurea americana)

China Aster

Gypress Vine

Datura (Angel's Trumpet)

Dimorphotheca (Orange African Marigold)

Emilia (Tassel Flower)

Helichrysum (Straw Flower)

Helipterum Humboldtianum

Hordeum

Humulus (Hop)
Hunnemannia(Bush Eschscholtzia) LiNuM (Flax)

LOBELIA

Job's Tears (Coix)

Pennisetum (Fountain Grass)

Petunia

Phlox Drummondi

Scabiosa (Pincushion Flower)

Sweet Sultan (Centaurea imperialis)

Thunbergia (Black-eyed Susan Vine)

VERBENA

Xeranthemum
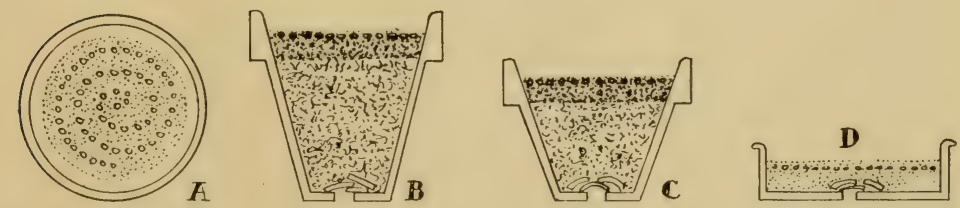

Fig. 3.- Sowing Seeds in Pots. A.- Sowing seed in a spiral insures space between the seedlings and their even distribution. B. - Seeds started in a standard pot. C. - Seed in a three-quarters pot or Azalea pan. D.-A seed pan. Note broken crockery in bottom of all pots and rough drainage material in the deeper ones. Also the space left at top of each pot for watering and ventilation. 


\section{SEED SOWING}

SOIL. Young seedlings have but few roots and leaves and are able to take little food from the earth. For this reason it is wise to sow seeds in loose, but not too rich, soil. A heavy clay which bakes should have ashes or sand added to it to loosen its texture. Manure, unless applied months before, is not necessary,

If you are going to sow seeds in boxes in early Spring, it is well to store a quantity of soil in the basement over Winter. Moisten it once a month to keep it in good condition but do not keep it wet, else it will sour.

Sowing IN Pots. When not more than 25 plants of each kind of flower are wanted, pots will be the easiest to manage. If possible use the shallow seed pots or pans which range in size from four to eight inches in diameter. Seedlings require but little soil and if there is too much of it, it sometimes becomes sour.

Clean the pots thoroughly by scraping them out with a knife and stiff paper. They are made porous so that air may enter the soil; keep them so. Place a piece of broken crockery over the hole in the bottom of each pot to prevent the soil from sifting out, but do not close the hole in such a way that water cannot pass out freely.

When deep, standard flower pots are used it is wise to fill them to within two inches of the top with coarse material. This may consist of grass roots, broken pottery, or the roughage left when soil is sifted.

The soil in which the seed is to be sown should be finely sifted and filled in to within an inch of the top of the pot. Filling the pots too full and failure to use enough soil are equally to be avoided. Press the soil down firmly and make it perfectly level; if otherwise, the water will settle to one side.

Sow the seeds thinly and in a spiral as shown in Fig. 3. This method is analagous to sowing the seeds in rows and is advantageous because one can more easily weed the seedlings. Large seeds are covered three times their diameter with sand. Why sand? Because the seedling sprouts can push up through it more easily than through soil. Furthermore, the young plants are less liable to become diseased in their young stages. Use special precautions in sowing the finer seeds, (See page 18.) 


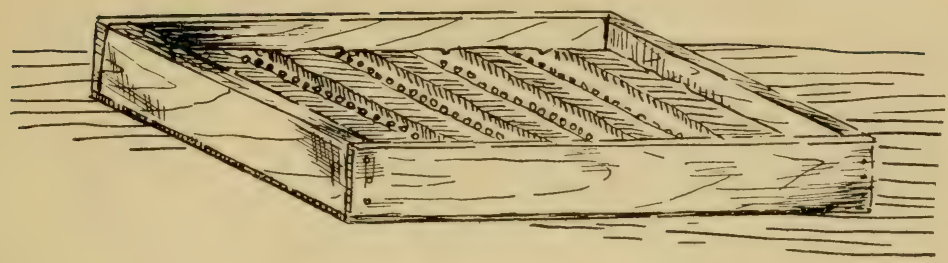

Fig. 4.-Flat for seed sowing.

Water the seeds thoroughly with a fine spray on the sprinkling can so that the soil is not washed. Cover the pots with panes of glass so that the moisture will not evaporate from them too quickly. Then shade the pots with a newspaper. Most seeds prefer to germinate in the dark, but as soon as the seeds have germinated the paper must be removed or the seedlings will be tall, spindly and weak. Full light must be available if one is to produce stocky, hearty plants. Compare the seedlings in figure 8, page 20.

Sowing in Boxes. When large quantities of flowers are to be grown it is well to sow the seeds in boxes or flats about three inches deep. It is a mistake to try to make these water-tight; rather place the bottom boards a quarter of an inch apart or bore five or six holes in the bottom to afford good drainage. Place some broken pottery over the holes and rough material in the bottom of the flats, following the plan given in connection with the use of pots for seed sowing.

There is one important point to remember when flats are used: Never sow the quick-germinating sorts in the same box with the slower kinds because when one needs light and water the other may be needing darkness and no water. When in doubt use a separate flat or pot for each sort. For example, it is unwise to sow Petunias

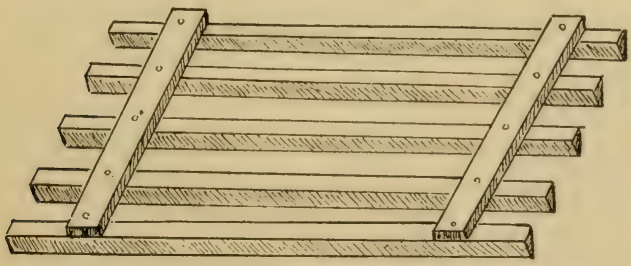

Fig. 5. - A handy frame for marking out rows in a seed flat. and Ageratum in the same flat with Sweet Alyssum. The Petunias will not all start together and some will take weeks to germinate, while the Sweet Alyssum will germinate in a few days. 
Sowing Out of Doons. Some gardeners who say with much emphasis, "I love flowers," sow seeds in such a way as to belie their words. With a hoe or rake they scratch the soil to a depth of an inch or so-and sow the seeds. The hot sun drys the surface soil. The seedlings fail to germinate, or, having germinated, find difficulty in sending their meagre roots into the heavy, sodden soil beneath. The sowers then say, "The seed was poor. I'll never buy any more seed from that firm." Had the soil been well spaded, had manure been added, or sand or ashes mixed with the surface layer, success would have attended their efforts. The first commandment of successful plant growing is to do your level best to fully prepare the soil.

Some seeds may be sown where they are to remain, others must be transplanted. Some seedlings are difficult to transplant; these are discussed on page 19. (See also fig. 6, helow.)

Seeds which are slow to germinate may be covered with burlap which will retain the moisture

Succeeding with Fine Seeds. Garden lovers who are successful in sowing the smaller seeds will usually have less difficulty with larger ones. By fine seeds we mean those of

$\begin{array}{lll}\text { Lobelia } & \text { Phlox } & \text { Snapdragon } \\ \text { Ornamental Tobacio } & \text { Poppy (all kinds) } & \text { Torenia } \\ \text { Petunia } & \text { Portulaca (Sun Rose) } & \text { Vereena } \\ & \text { Salpiglossis } & \end{array}$

In sowing these follow the recommendations already mentioned but do not cover the seeds with soil. When pots or flats are employed use a very poor grade of tissue paper as a cover for the seeds and do not omit the pane of glass over the pot or box. Some persons find it advisable to thoroughly water the soil before sowing, thus climinating the danger of washing away the tiny seeds.

Small seeds sown out in the open are best covered with burlap which can be sprinkled from time to time.

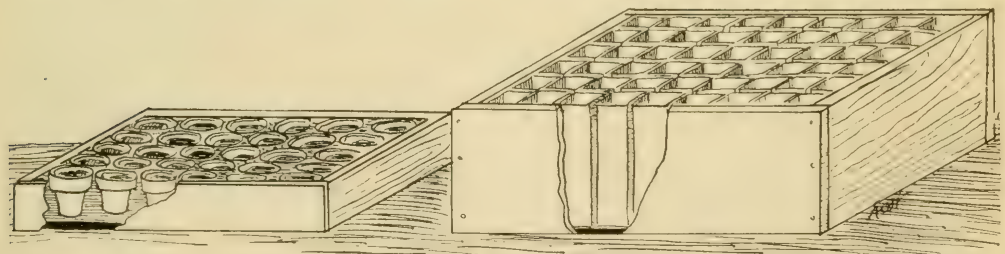

Fig. 6.-For seedlings hard to transplant, small pots or paper bands may be used to advantage. This is an especially good way to start Sweet Peas. Place soil between the pots to prevent them from drying out quickly. 


\section{TRANSPLANTING}

CENERALLY speaking, most annuals are sown too thickly and

I are not transplanted or thinned out soon enough. Tall, leggy, crowded seedlings are disappointing.

When the first true leaves appear the plants should be carefully lifted and transplanted. Each annual develops best when given plenty of soil and air; and experience teaches us the proper space each sort requires. (See under cultural notes, pages 31 et seq.)
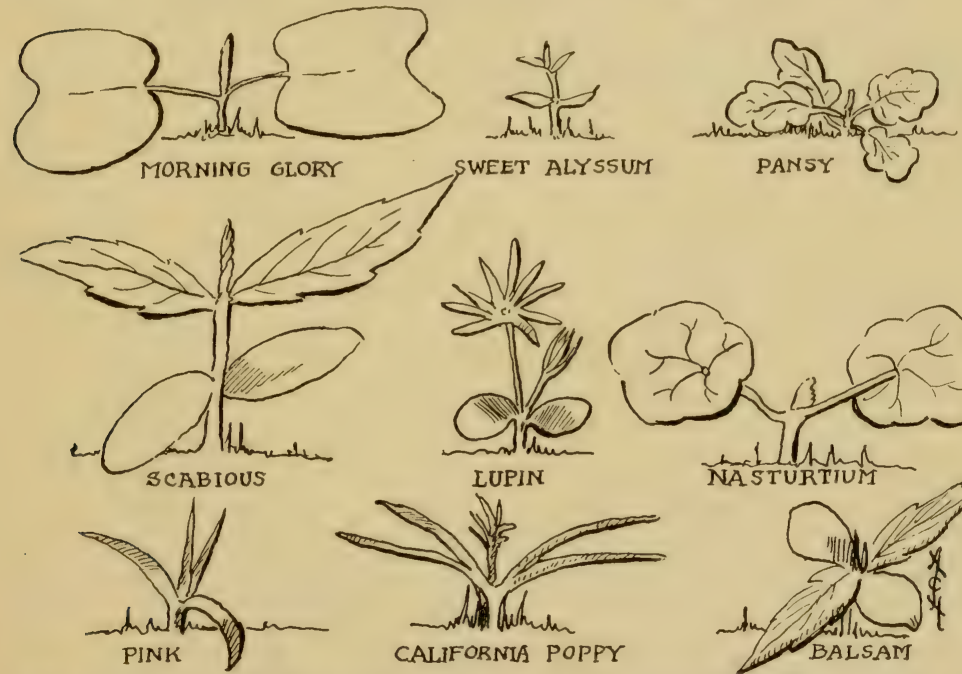

Fig. 7.- Seedlings of some common annuals, showing the seed leaves and the f.rst true leaves. Most seedlings are ready to transplant at this stas.e.

Difficult to Transplant. Some annuals which do not stand transplanting well should be thinned. It takes a brave hand to pull the surplus young hopefuls and an optimistic mind to believe that the remaining seedlings will ever occupy the space recommended. The Pea-like and Poppy-like annuals and those with long unbranched roots are the ones most difficult to transplant. The following reference list of such sorts will be found useful: 


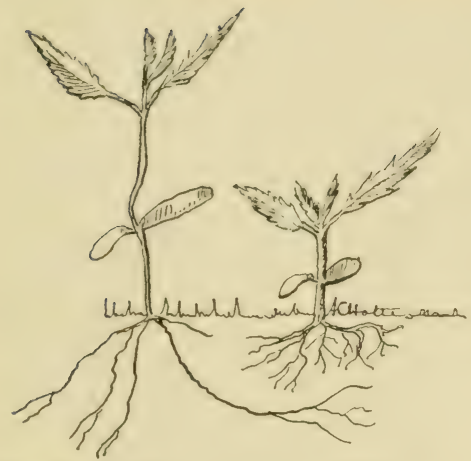

Fig. 8.-Good and poor seedlings contrasted. The poor one at the left is tall and spindly - the seed was sown too thickly and the plants got too little light. Note also its long, unbranched root system which will make it hard to transplant without a ckeck.
Argemone
Poppy) (Mexican Prickly

Eschscholtzia (California Poppy) Hunnemannia (Giant Yellow Tulip Poppy)

LAVATERA

LUPINE

Mignonette

Poppy (Shirley and Opium)

Sweet Peas

Sweet Sultan

Such annuals are well sown in individual pots-three or four seeds in each. When the seeds germinate all but one of the seedlings may be removed. See figure 6 , page 18.

\section{How and When to Trans-} PLANT. Transplant when the seedlings crowd each other. Water the soil several hours before transplanting in order that as much as possible will adhere to the roots. It is well to choose a dull day for moving tender seedlings. If the sun is shining, the seedlings and the larger plants as well, should be covered with newspaper or flower pots so that their tops will not dry out. Two other precautions are advisable: puddling the roots and shortening the tops.

If one makes a thin mud of clay and water and dips the roots of the plants into it, a layer of soil will be formed about the roots and check evaporation, a precaution especially valuable when the soil is dry.

Whenever we dig a plant we injure its roots. This being the case, it is generally advisable to cut off a portion of the leaves to create a balance between the injured roots and the leaf area.

If these things are done plants may be moved at any time if watered thoroughly and shaded immediately thereafter.

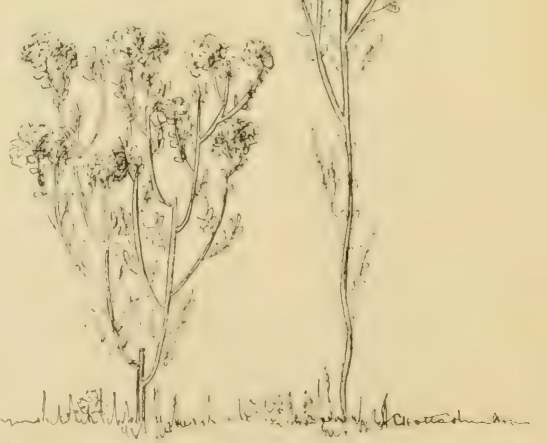

Fig. 9.-The effect of pinching or topping is shown in the plant at the left. 


\section{PINCHING}

COME annuals do not branch as freely as we might wish, while others hurry into bloom before the plants attain a desirable bushy form or sufficient size. If we pinch them, that is, nip out the top buds, they will usually branch freely and bloom more abundantly. In most cases one had best not pinch all the seedlings because pinching often delays the bloom. It is, therefore, wise to pinch half of the plants, allowing the others to bloom naturally. Pinching can thus be both beneficial and harmful, and should be done judiciously. (See fig. 9,)

Crowded seedlings should not be pinched, nor should the varieties whose beauty depends upon a large rocket spike of bloom. Most annuals branch freely when given space to develop, and do not require pinching.

\begin{tabular}{|c|c|}
\hline Pinch These & SALPIGLOSSIS \\
\hline GERATUM & SNAPDRAGON \\
\hline BROWALLIA & Verbena \\
\hline BUTTERFLY FLOWER (Schizanthus) & Do Nol Pinch T Tese \\
\hline $\begin{array}{l}\text { Chrysanthemum, Annual } \\
\text { Perilla }\end{array}$ & Gocksconb \\
\hline Petunia & EVERLASTINGS \\
\hline Phacelia & Impatiens (Balsam) \\
\hline Phlox & POPPY \\
\hline PInks & Sтоск \\
\hline
\end{tabular}

\section{THE HOE vs. THE HOSE}

THE careful gardener conserves more water than he applies. By 1 preventing the soil from baking and cracking at the surface we prevent the escape of moisture into the air and thereby conserve it below. Plants give off large quantities of water from their leaves but if one keeps the soil well stirred after each rain there will be but little loss of moisture from the dry, powdery surface.

Those flowers which need the most water are usually found to be growing on soil that has not been prepared deeply.

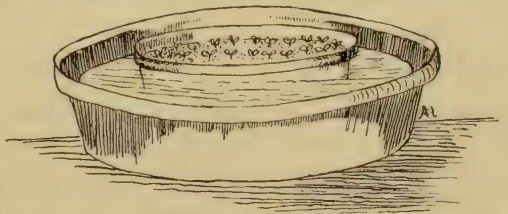

Fig. 10.-To water fine seeds or seedlings place the pot or pan in a dish of water so the moisture can seep up from below. Less damping-off follows this method. 


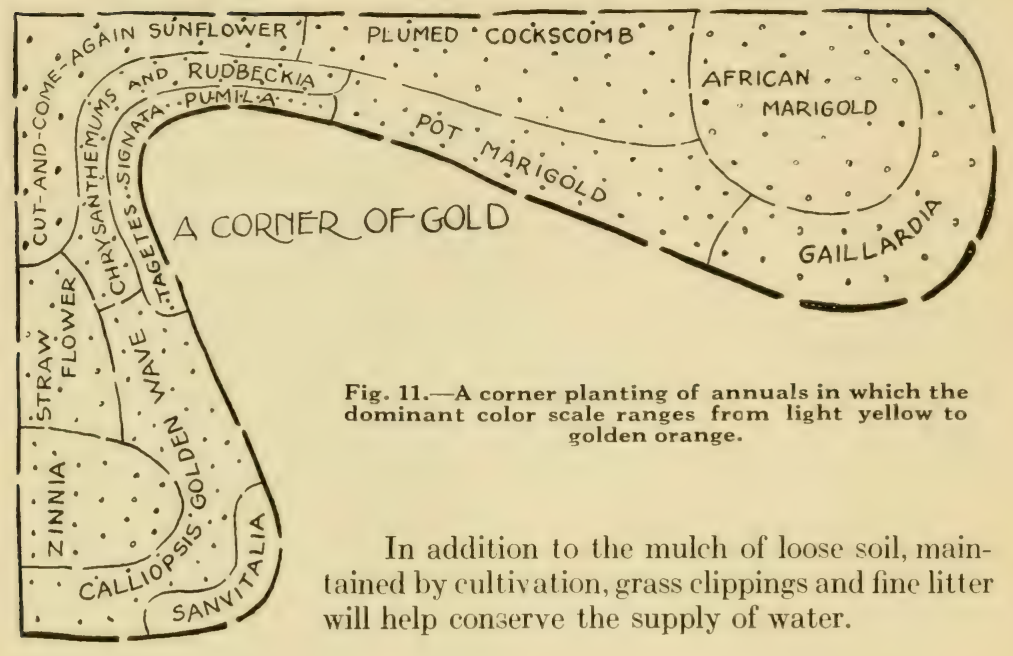

\section{WATERING vs. SPRINKLING}

More plants are injured by sprinkling than by drought. If you believe that water is needed, make a good job of it and do not merely give the plants a "dribble" each day. Seedlings given frequent sprinklings, soon become diseased. Water them well, then wait until they are nearly dry before doing it again. Seedlings are easily watered by placing the pot in which they are growing in a dish of water so that the moisture rises from below. (See fig. 10.)

It makes little difference in the Summer whether one waters in full sunlight or at night, except that water applied in the evening will be more effective because the sun has no chance to quickly evaporate it. However, seedlings started early indoors or in hotbeds should be watered in the morning so that moisture will not stand upon the leaves over night.

Persons sometimes notice that their plants have wilted when watered in the sunshine. This has been due to the fact that they have merely sprayed the leaves and have not applied enough water to the roots. When there is sufficient water at the roots the tops will not wilt unless the weather has been very dull and the growth has been abnormally soft. 


\section{ANNUALS AND SHADE}

As a general statement it may be said that annuals are not lovers of shade. Some succeed when grown in partial shade, however, and as there are many such nooks in our gardens the following sorts may be recommended for them:

China Asters

Clarkia

Godetia

LUPINE

MONKEy Flower
Musk Plant

Nemophila (Love Grove)

PANSY

Schizanthus (Butterfly Flower) SNAPDRAGON SWeEt AlysSum Sweet Sultan

\section{FALL SOWING AND SELF-SOWN ANNUALS}

M ANY of the hardiest annuals can well be sown in the Fall. Under these conditions the seedlings germinate early in the Spring and come into bloom as quickly as if the seeds had been sown indoors or in a hotbed.

Some of them may germinate in the Fall and make some growth before Winter, which is advantageous, for then they usually start growing after Winter passes as though nothing had happened.

It is wise to place a light mulch of finely pulverized, well-rotted manure over beds of Fall-sown plants. Let it be only an inch or so thick, for it must not choke out the seedlings.

The following annuals may be sown in the Fall:

Alyssum, Sweet

ANTIRrhinum (Snapdragon)

Galendula (Pot Marigold)

Centaurea (Cornflower)

Glarkia

Delphinium (Annual Larkspur)

Dianthus (China Pinks).
Echinocystis (Wild Cucumber)

Eschscholtzia (California Poppy)

IBERIS (Candytuft)

Nigella (Love-in-a-Mist)

Pansy

Papaver (Poppy)

Sweet Peas

Besides these, many sorts self-sow their seed. That is, they send up what the gardener calls "volunteer plants." Let us read what Helen R. Albee writes in Hardy Plants for Cottage Gardens about self-sown annuals.

"My walks are covered with sand, for it does not track into the house as the native soil would. Sand has another advantage; it serves 
as a seed bed for a multitude of self-sowing plants. When I desire particularly strong annuals, I do not plant the seed; I look about my walks until I find them. They have stood the test of Winter and a frosty Spring. Anyone who has watered seeds to young planthood has a genuine admiration for self-supporting, walk-grown plants."

If the border is somewhat protected with a mulch of garden trash or manure many sorts will spring up. It is then that the garden lover is pleased that he knows the differences between flower seedlings and weed seedlings. A few seedlings are shown in figure 7, page 19 .

Watch out for the following annual seedlings; although your climate may not favor all of them, many of them may be depended upon to self-sow:

Ageratum (Floss Flower)

ALySSUM, SWEET

Amaranthus (Love-Lies-Bleeding, or Prince's Feather)

Argemone (Prickly Poppy)

Balsam (Impatiens)

Browallia (Amethyst)

Galendula (Pot Marigold)

Galliopsis (tinctoria)

Candytuft (Iberis)

Gentaurea (Cornflower)

Clarkia

Gueome (Giant Spider Plant)

Cosmos

Echinocystis (Wild Cucumber)

Eschscholtzia (California Poppy)

Euphorbia (Snow-on-the-Mountain)
Four-o'Glock (Mirabilis)

Gaillardia (Blanket Flower)

Godetia

Gypsophila (Baby's Breath)

Косніа (Summer Cypress)

LARKSPUR (Delphinium)

Marigold (African and French)

MorNING GLORY

Nigella (Love-in-a-Mist)

Nicotiana (Ornamental Tobacco)

PANSY

Petunia

Poppy (Papaver)

Portulaca (Sun Rose)

SNAPDRAGON

SUNFLOWER

ZINNIA

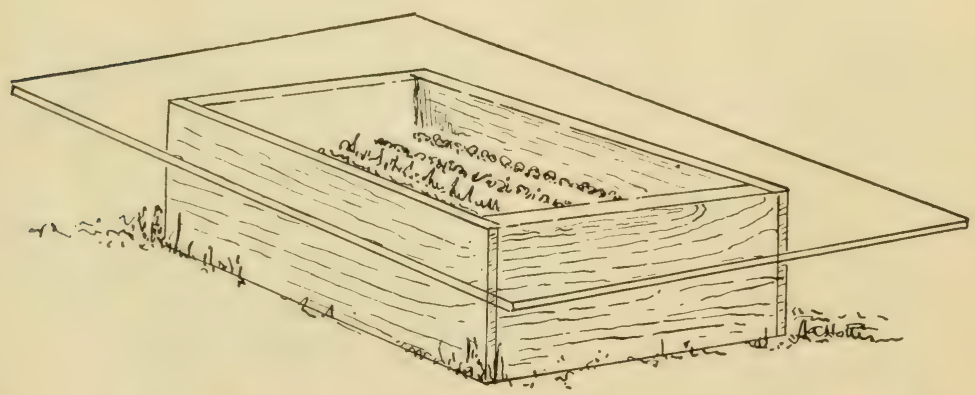

Fig. 12.-A Forcing Box.-A soap box with a pane of glass over it will retain the heat of the sun and be useful for early seed sowing. 


\section{HOTBEDS AND COLDFRAMES}

SOME homes have greenhouses and others have good sunny win$\checkmark$ dows; persons without either should provide means for starting some early plants for the garden.

The common hotbed is a frame into which manure may be packed to furnish heat to a layer of soil on top. Most home gardeners will find that a frame large enough to be covered by one three foot by six foot sash is the proper size. Hotbed sash had best be purchased but the frame may be made at home or bought ready made.

A temporary hotbed may be made by constructing a frame of the same size 12 inches high at the back and 8 inches high in front. This is set upon a pile of manure a foot and a half deep. Less heat is lost, however, if more permanent frames are constructed. The preparations should begin in the Autumn with the digging of a two-foot pit in which the frame is built. The accompanying cut shows how to construct such a frame

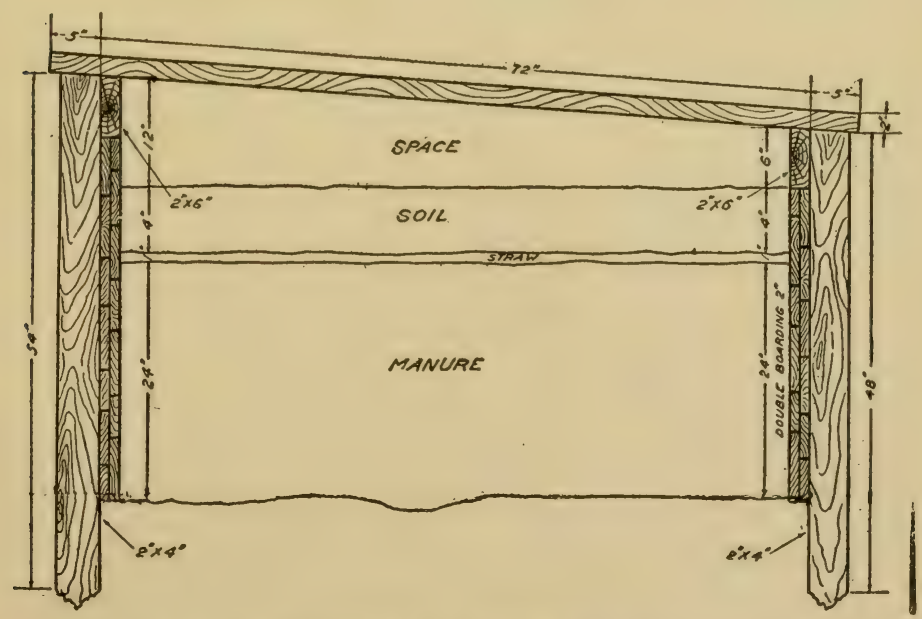

Fig. 13. - Section of a hotbed frame with details of measurements. Reproduced from a Cornell bulletin. 
Preparation of Hotbed. Cover the frame with boards during the Winter to keep out the snow. Early in March in some localities, such as central Ohio (the last week in March in latitudes farther north), the frame may be filled with fresh horse manure. (Decayed manure has stopped fermenting and lost its heat.) Before it is used the manure should be turned several times to insure even heating. Spread it in the hotbed evenly and tread it down rather firmly. A layer of straw on the manure will distribute the heat uniformly through the hotbed. Over the straw place about four inches of loose, light soil. Do not use a wet, heavy soil. If possible store the soil in the basement and make it friable by adding to it manure, leafmold or sand. Level the soil nicely and cover the bed with the sash.

Management. Use a thermometer to take the temperature of the soil which may run up above $100 \mathrm{deg}$. F. for a few days. When it drops to $90 \mathrm{deg}$. the seed may be sown. Mats spread over the sash will help to retain the heat on the coldest nights. For this purpose straw mats may be purchased or made, but old quilts or blankets may also be used. The sun will heat up the frames so that even in freezing weather the temperature will rise above $100 \mathrm{deg}$. unless the sash is opened a little during the day. Keeping the frame tightly closed will cause the burning of tender seedlings. When the plants need water give it only on sunny mornings. Opening the sash to water at night causes a loss of heat; evening watering also results in the spread of mildews and other diseases.

Coldframes. Coldframes are similar to hotbeds except that no pit is necessary because no manure is used. Sun shining through the sash, as we all know, will heat the frame considerably and by the use of protecting mats and blankets we can keep it quite warm even at night. The management of a coldframe is the same as that of a hotbed. Seeds sown in a frame will come into bloom several weeks earlier than those sown outdoors. Frames are useful also for carrying some annuals through the Winter. Many of the plants listed in this book are really perennials that will not stand the severe weather of northern Winters.

Again, annuals started in a sunny window are often rather soft in growth and sometimes perish when set out in the garden, especially if the weather is either hot or cold. By placing these plants in these coldframes we can gradually adapt them to outdoor conditions. The professional gardener calls this "hardening-off the plants."

Forcing Box. A very useful "miniature coldframe" for growing a few plants is illustrated in figure 12, page 24 . It is an ordinary box from the grocer's covered with a pane of glass. 


\section{ANNUAL FLOWERS AND THEIR USES}

\section{These Please Us with their Fragrance}

GOR the eye there are many pleasures among our annuals but relatively few of these flowers possess the power to delight us with their sweet fragrance. It can be said that a certain flower is light pink in color, and funnel-shaped, but for kinds of fragrance there are few truly descriptive words except such comparisons as lemonscented, clove-scented, etc. Each person must experience each odor to know what it is like. Personal tastes differ widely as to what shall be called fragrance and what constitutes an objectionable odor. The following annuals are definitely scented:

Ageratum. Delicate

Alyssum, Sweet. Delicate

Cцеомe (Giant Spider Plant). Some call this an odor although it is not noticeable unless the plants are brushed or bruised

Heliotrope. Generally considered the par excellence of fragrance

Hop Vine. Tastes differ

Marigold. By all considered an odor; intolerable to some but unobjectionable to others

Marigold, Pot. An odor but not generally disliked

Mignonette. Called delightful by all
Musk Plant. Individual

Nasturtium. Admired by some

Ornamental Tobacco. A delight in the evening

PANSY. A refreshing fragrance

Petunia. Heavy; to some persons depressing

Scabiosa. Dainty

STOCK. Unusual; fresh

Sweet Peas. Delicate; enjoyed by all

Sweet Sultan. Delicate

Verbena. Some sorts are Arbutuslike

Verbena, Lemon. Really lemonscented

\section{These Flowers are for Picking}

Some persons have made themselves ridiculous by contending that no flowers should ever be picked, "that they are better left upon the plants than ripped from the soil only to die in the house." Such ideas are not worth consideration. We do not rip our flowers from the garden to die. We pluck them to bring Springtime and harvest color to our tables, our windows, our friends, our churches and our many home and social occasions. If they wither it is after they have served their purpose, even as each of us must do. A flower in the hand is often worth twenty on our own or our neighbor's bush. And 
with many of our annuals, the more profligate we are in cutting the flowers the more abundant is our return.

The wise way to have an abundance of flowers for cutting is to sow them in rows far enough apart so that a wheel hoe may be used. When so planted they are easily cared for and armfuls may be cut with no regrets.

Some of our annuals are chiefly valued for their masses of bloom in the gardens; others, because of their long stems and good keeping qualities are useful for vases. The list below includes the outstanding sorts only:

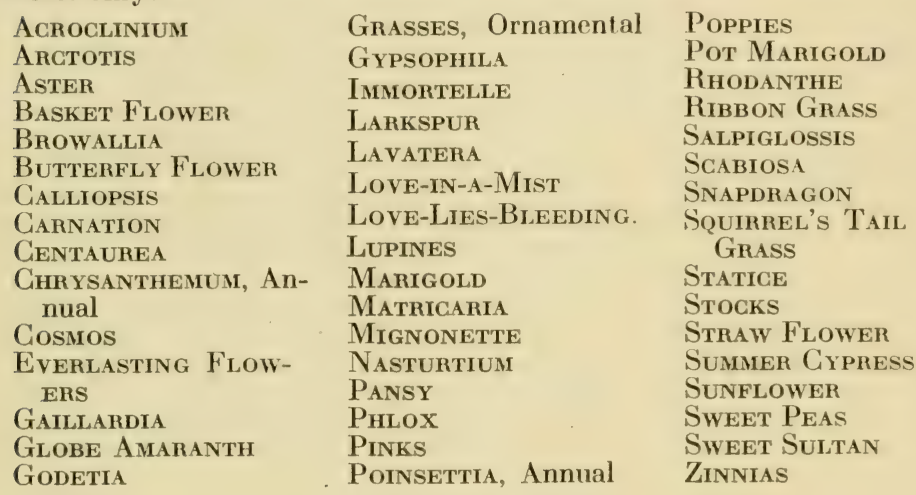

\section{Other Useful Lists}

Foliage Annuals

Amaranthus. Joseph's Coat and others

Argemone (Prickly Poppy)

Gastor Bean

Grasses, Ornamental (see p. 95)

KocHIA

Perilla

Vines, Annual (see p. 105)

For temporary hedges

BaLsam

Fountain Grass

Four o'Glock

Helichrysum

KOCHIA

For moist places

NeMOPHILA
Ageratum

Edging Annuals

Alyssum, Sweet

BABY'S BREATH

Galliopsis (Choose dwarf variety)

Candytuft

Celosia (Choose dwarf variety)

LOBELIA

MARigold (French and Mexican)

Nasturtiums (Dwarf sorts)

NeMOPHILA

PANSY

Petunia

Phlox, Annual

Portulaca

Sanvitalia

Scarlet Flax

Snapdragon, Dwarf

Swan River Daisy

Verbena 


\section{For poor soil}

Alyssum, Sweet

Balsam (Impatiens)

Bachelor's Button

California Poppy

Cialliopsis

Godetia

Joseph's Coat

LOVE-LIES-BLEEDING

Nasturtium

Poppy

Pontulaca
Pot Marigold

Prince's Feather

For hot, dry places

California Poppy

Fig Marigold

ICE Plant

Mrmosa (Sensitive Plant)

Morning Glory (Dwarf)

Perilla

Phlox, Annual

Portulaca

\section{A CHAIN OF TEN LINKS}

A chain is no stronger than its weakest link. There are ten links in the chain called "Success with Annuals."

1. Buy good seed. Good breeding in flowers is as important as good breeding in livestock.

2. Try some new sorts even if you do not know their names. Variety is the spice of the garden.

3. Sow a space with flowers large enough to make a good eyeful. One of nature's laws is abundance.

4. Prepare the soil thoroughly, adding some well-decayed manure. Use the spade before the rake. Some folks do not do this in sowing annuals and then wonder why the seed germination was so poor.

5. Sow the seed thinly. This is sometimes a difficult task so that good gardeners frequently mix sand with fine seed.

6. Do not sow deeply. Consider the load that the little sprout has to lift in pushing through the soil. The finest seeds should be covered not with soil, but with a piece of burlap.

7. Thin out or transplant so as to let the plants stand the proper distance apart. Crowded seedlings are tall and leggy. Do this early in their growth, so that there is no struggle for existence.

8. Cultivate. This will be easy if the plants are far enough apart.

9. Annuals stop blooming when they are allowed to ripen seed. Remove the fading flowers. Better yet, pick the flowers while fresh and enjoy them in the house.

10. Water thoroughly or not at all. Do not coax the roots to the surface by playing with the water and sprinkling. During very dry weather soak the soil; at other times, use the hoe. 


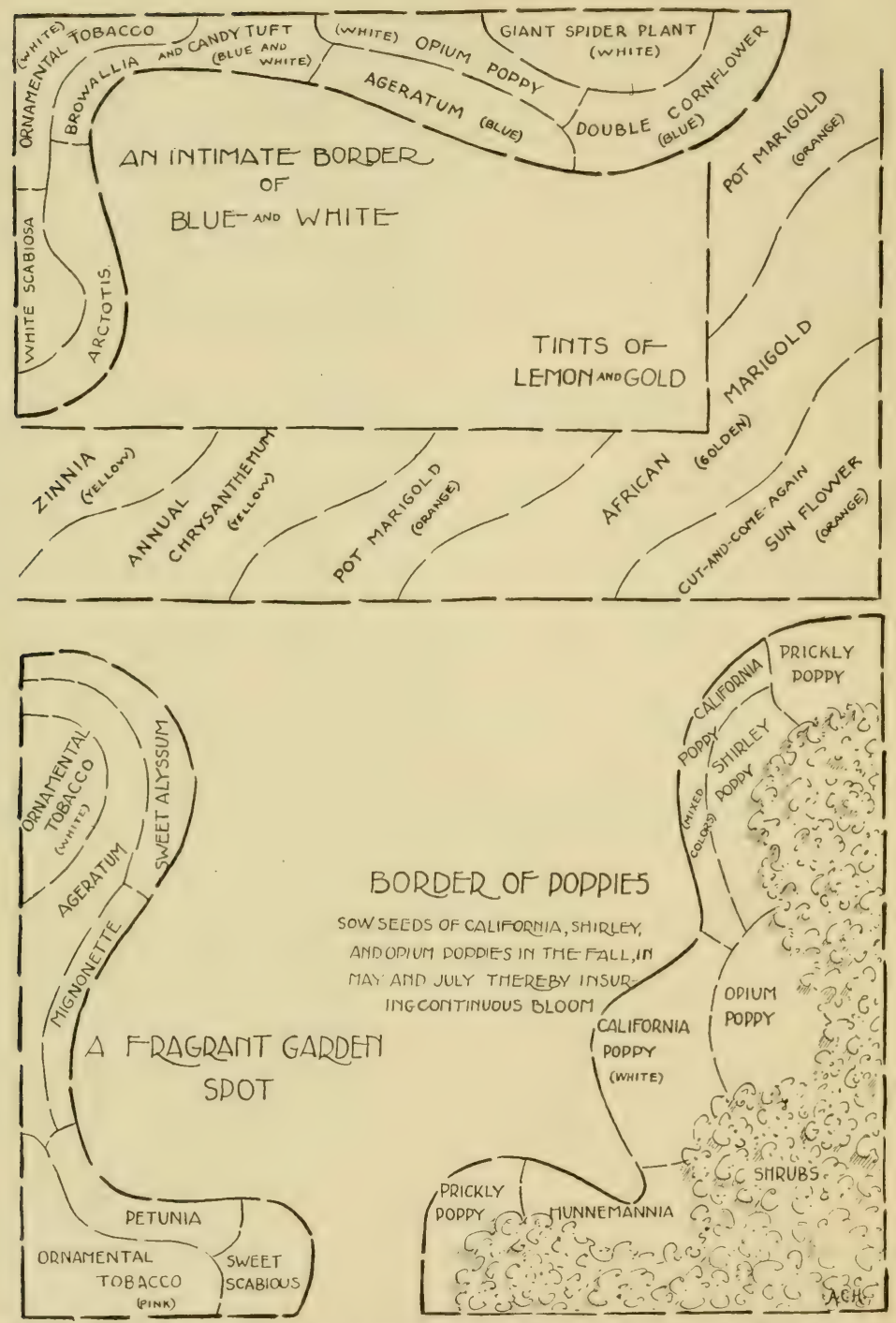

Fig. 14.-Four suggestions for arrangements of annuals with which to beautify garden nooks and corners. Above, are shown combinations of blue and white and lemon and gold respectively. Below, the borders provide fragrance in the one case and a solid Poppy effect in the other. 


\section{ANNUALS OF MERIT}

\section{Ageratum-Floss Flower}

UsE. Blue flowers are rather rare among annuals. This is one of the reasons for the great popularity of the Ageratums. The flowers are dainty and feathery, often delightfully fragrant, and usually completely cover the plants. There are attractive dwarf, tufted plants as well as tall, upright growers. The dwarfer sorts appear to produce much more bloom, although the tall sorts furnish longer-stemmed cut flowers. The blue of the Ageratum combines well with pink in the garden. The white varieties are not as attractive as many of the other white annuals. (See fig. 15, page 32.)

Height 6 to 24 inches.

Culture. The Ageratum is half hardy. Seed should be sown indoors any time between January and April in order to get early bloom. When sown in the open ground (which should not be done before the soil is warm) the plants do not reach their full splendor until Fall.

Keep the faded flowers picked, otherwise the plants will stop flowering and the clear blue effect will be marred.

\section{Alyssum, Sweet}

The Sweet Alyssum is one of our most useful white edging plants. Seed catalogs list many varieties of Alyssum maritimum, some being dwarf, tufted plants and others more or less trailing. (See frontispiece.)

UsE. The various sorts are admirably adapted to rock gardens, old-fashioned gardens, pots, hanging baskets and borders around other flowers. They combine well with other flowers in attractive vase arrangements. It is well to buy seed in quantity so that a little may be sown in any space in the garden where other flowers have failed. Some seed may be even sown for Winter bloom in the large pots used for other flowers.

Height 6-12 inches.

Culture. Sweet Alyssum is a hardy annual. Seed may be sown as soon as the frost has left the soil in early Spring and the plants will bloom in less than six weeks. To have a succession of bloom sow seed 

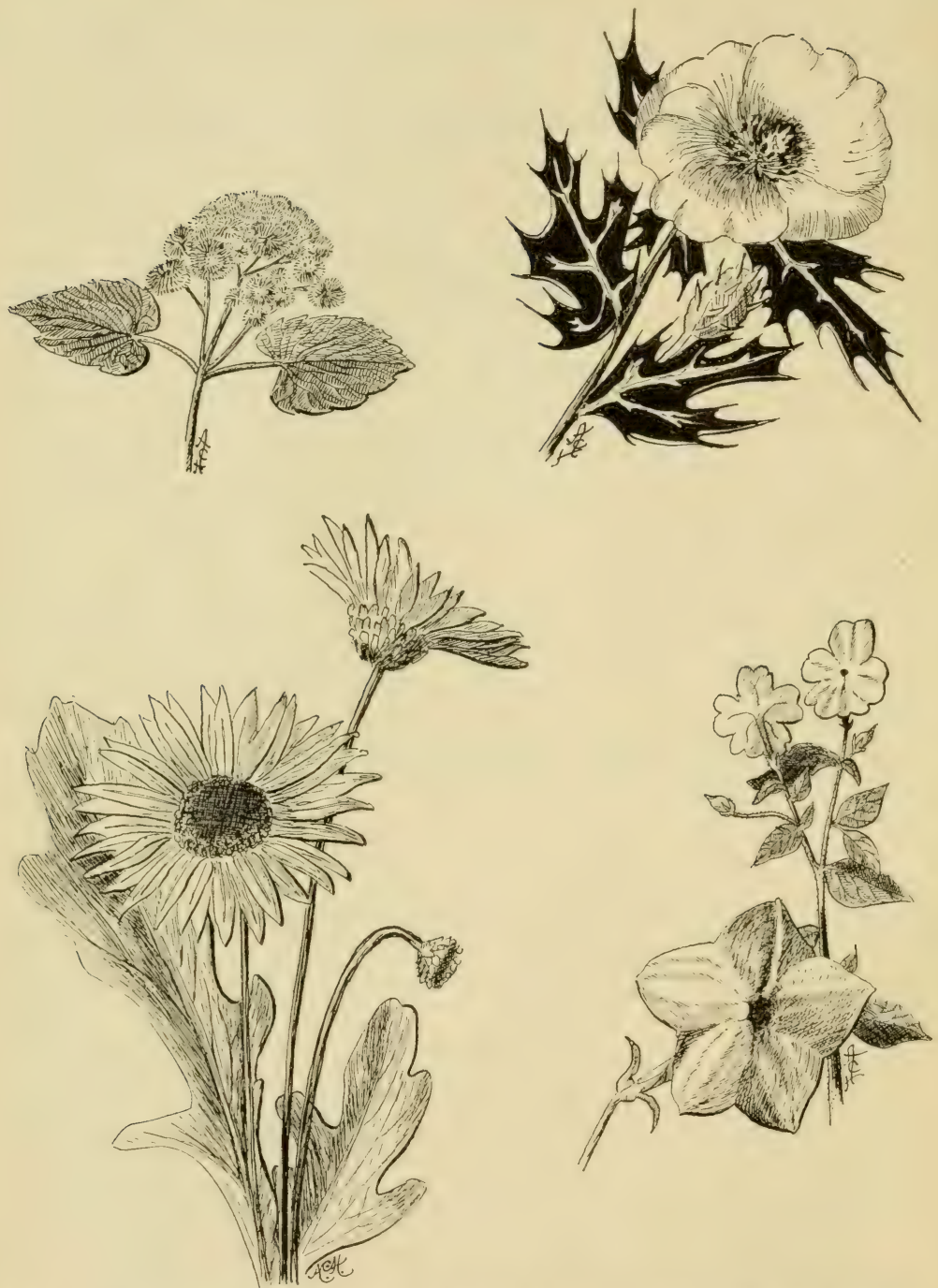

Fig. 15.-Upper left. Ageratum, a blue flower borne in great profusion; lower left, Blue-eyed African Daisy, has white blossoms with steel-blue centers; upper right, Agemone, has yellow flowers and spiny leaves and seed capsules; lower right, the Agemone, has yellow flowers and spiny garden gem, while the larger bloom is B. speciosa, a useful pot plant. 
at least every month. If the seed is sown thinly, but little transplanting will be necessary, although the plants should preferably stand 6 to 8 inches apart. Cut the plants back when they have passed their main season of bloom and they will shortly produce a second growth.

\section{Amaranthus}

There are many forms of Amaranthus, some of which have highly colored foliage while others have long spikes of blood-red flowers.

Species. Love-Lies-Bleeding (A. caudatus) has long, drooping spikes of flowers resembling heavy chenille. Height 5 -6 feet.

Prince's Feather (A. hypochondriacus or A. cruentus). The flower spikes are erect, and the leaves are often blood-red. Height $4-5$ feet. (See fig. 16, page 34.)

Joseph's Coat (A.tricolor). The foliage is beautifully marked with rich scarlet, yellow, green and white. Height 18-24 inches.

Fountain Plant (A. salicifolius). The bronze or orange leaves are long, narrow and wavy margined.

Uses. The various sorts of Amaranthus are closely allied to the Pigweeds and Celosias, but the latter are daintier and have flowers of lovelier colors. At best these annuals are rather coarse and have only a limited value in the garden. They will grow in the hottest and driest locations. In rich soil the colors are not as brilliant and the plants grow foliage principally.

Culture. Seed may be sown in the hotbed or window of the home in March; or, if one prefers, the sowing may be deferred until the soil is warm outdoors. Thin the plants, as they require much space.

The various sorts do not come perfectly true from seed; seed from the best plants often produce specimens with inferior flower spikes and less highly colored leaves.

\section{Arctotis-Blue-eyed African Daisy}

Uses. These lovely, Daisy-like flowers are excellent for cutting. The upper sides of the petals are white and the reverse lilac-blue, with the center of the flower steel-blue. The foliage is grey-green. Cut blooms last a week, closing each night and even some of the undeveloped buds will open in water. The flower stems are often from 10 to 12 inches long, the plants being 2 feet tall. (See fig. 15.)

Culture. Sow the seeds either in the open ground or in a hotbed. The seeds germinate in less than a week and the plants will bloom from July until frost. Transplant the seedlings to stand 12 inches to 18 inches apart. 


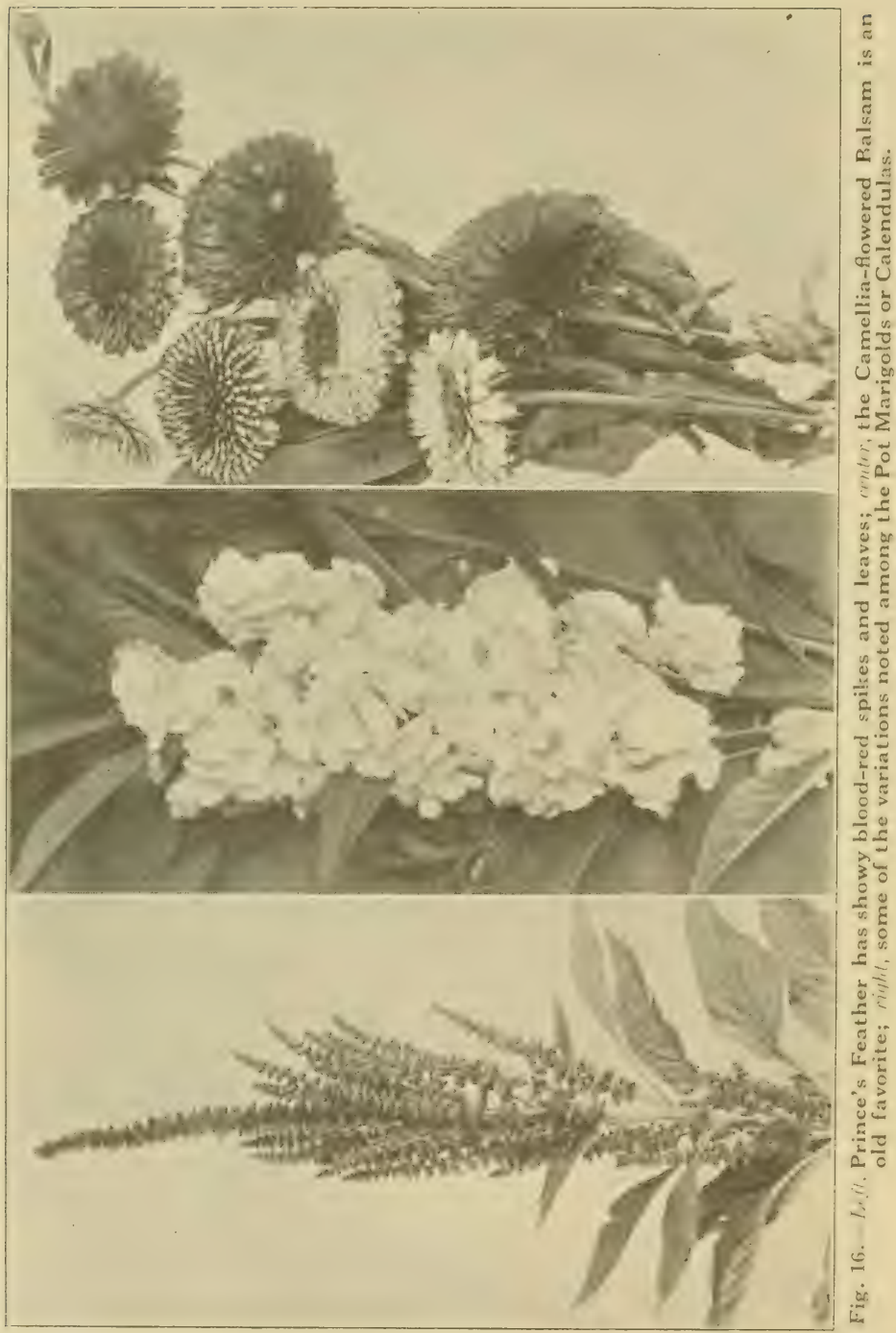




\section{Argemone-Prickly, or Mexican Poppy}

These prickly-leaved, white and yellow Poppies are very interesting to grow. The white flowered sort (4. grandiflora) is really a perennial, but in the colder northern states it is used as an annual although not as free flowering as the yellow species (1. mericana). The latter frows 3 feet tall and has white-veined leaves. The flowers appear in rarly July and (ontinue until freezing weather. (See fier. 1.5, page 3\%.)

Because of its beautiful variecated leaves, the yellow sort is an excellent foliage plant.

Culture. The seedlings are difficult to transplant although they may he lifted when very small if taken up with a hall of soil. $I 1$ is lest to sow the seeds thinly so that it will not be necessary to move them. The plants will self sow.

\section{Balsam-Impatiens}

The Garden Balsam or Lady slipper (Impatiens balsumina) is an old-fashioned favorite. The double and semi-double sorts, well called Camellia-flowered, are practically the only ones grown. These plants are elosely related to the wild Touch-me-nots and, like them, have characteristic seed pods which open suddenly when touched. The bloms are of many delicate colors - white, flesh-pink, salmon, rose, purple and violet. The plants grow 18 inches tall and the stems are juicy and thick. (See fig. 16.)

Usis. Balsams are rather formal plants of neat, compact habit. The flowers are produced close to the stem almost hidden among the leaves, and some gardeners remove a few of the leaves to better disrlese the blessoms. The plants may be grouped in the border or used as low hedges.

Culture. Seed may be sown indoors, as growing the plants in small pots for a few weeks will dwarf them and make them more compact. Or sow directly in the soil out of doors in May. The plants will cover 12 inches to 18 inches of space. The flowers grow nicely in wellenriched sandy soil, and prefer full sunlight.

\section{Browallia-Amethyst}

The Browalliats are extremely dainty. (One sort, B. speriosa, with flowers an inch in diameter is grown in greenhouses; the other common sort, more useful for the garden, is $B$. alata (demissa) which has tiny blue (sometimes white) flowers about three-fourths of an inch in 
diameter. It grows about 18 inches tall, but if very crowded will bloom when only an inch and a half tall. Browallias may be planted among Pansies in which case they grow above the Pansies, producing a little canopy of blue stars. The flowers are good for cutting. $B$. speciosa may be grown in pots in the house. The Browallias are related to Petunias and have the same good characteristic of producing hundreds of flowers. (See fig. 15, page 32.)

Gulture. Sow B. alala when the soil has warmed up slightly in the Spring. If the bed is protected over Winter the plants often self sow. Let the plants stand 6 inches apart. If some plants are pinched (see page 21) they will branch out nicely, remain dwarf and bloom later in the season.

\section{Calendula-Pot Marigold}

When Shakespeare mentioned the Marygold he meant this annual which for wealth of bloom, is without a rival. As the plants self sow, many persons have them in their gardens year after year. Flowers from such chance seedlings are often small and single so that some persons have tired of them, but were they to purchase seed of some of the better varieties they would experience a distinct surprise for these double, pure gold, lemon and sulphur-colored varieties are most attractive. The stems are long and strong so that a few plants will furnish a vase of flowers every day. The plants start to bloom when small and continue even after the first frosts - but in order that they shall do this the fading flowers and seed heads must be removed promptly. Few flowers pick as easily as the Calendula, the stems breaking off readily when pulled. (See fig. 16, page 34 .)

Culture. Sow the seed in the open soil in early Spring whenever it can be worked. Allow 12 inches to 15 inches between the plants. The seedlings transplant readily.

\section{Calliopsis-Coreopsis}

The name Calliopsis is given to the annual forms of Coreopsis. These wiry-stemmed annuals provide some of the brightest flowers of the garden in golden yellow, velvety crimson and polished mahogany.

Species. Coreopsis Drummondii (Golden Wave) has blossoms 3 inches in diameter, golden yellow with a few pencil lines of brown on each ray flower. It closely resembles the perennial sort (C. lanceolata) except for this center. Height 18 inches. (See fig. 17, left, page 37.)

C. tinctoria (C. elegans and C. marmorata). There are many va- 

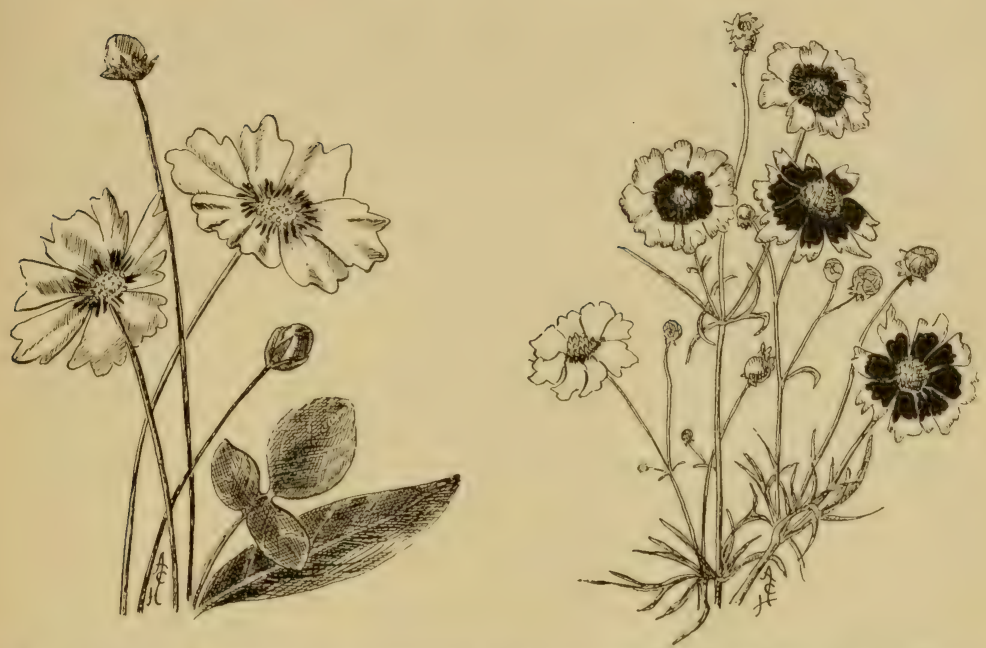

Fig. 17. - Left, Coreopsis Drummondii, a most useful yellow flower for cutting; right, C. tinctoria has tiny blossoms of gold, each marked with mahogany.

rieties of this brilliant species. The flowers are usually smaller than those of the first named sort, but they are marked with large blotches of mahogany, chestnut, crimson, garnet and purple. Height 1 foot to 3 feet, according to the variety. (See fig 17, right.)

UsEs. Calliopsis is an excellent flower for massing in an annual border. The flowers are useful for cutting because of the long stems. The dwarf, bushy varieties are good edging plants. Many varieties of C. tinctoria are slender in growth and may be set out among the lower growing annuals. The intensely brilliant flowers borne upon their tall, slender stems, dance in the breeze as though not supported at all.

Gulture. Generally the seed of Calliopsis is sown where the plants are to bloom and the seedlings thinned to stand 8 inches to 12 inches apart. They prefer a sunny spot. The plants often self sow. Clip off the developing seed heads in order to induce the production of more flowers.

\section{Candytuft-Iberis}

The neat heads of Candytuft bloom are always greatly admired. Many persons confuse this flower with Sweet Alyssum which bears smaller flowers in smaller clusters. The white Candytuft is most often seen, but there are purple, lavender and crimson sorts. 
The two spereses differ in the form of their clusters. Iberis amare

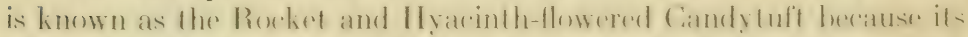
white flowers are arranged in longe elusters. In l. ambellater. which includes the rodered forms, the flower heads remato umbellate. that is. short and comparet. Both of the forms attain 19 inches to lis inches in height. (See fig. 19, page 40.)

Lises. Both forms provide superde edeing planis for the garden. They bloom profusely and the fragrance of some of the sorts commends them as cut flowers.

Culture. Sow the seed where it is to wrow as early as posibible in the Spring, or even in the Fall. Thin the plants te (; or 8 inches apart. Fall-sown seed blooms in June; Springr-sown seed in July and August. Sowing seed suceessively over several weeks will insure flowers throughout the Summer.

\section{Castor Bean-Ricinus}

Were these words meant fior boys and girls only we fixar they would never be read, because of the unpleasant memories associated with this plant. In the garden, however, Castor Bean plants are interesting

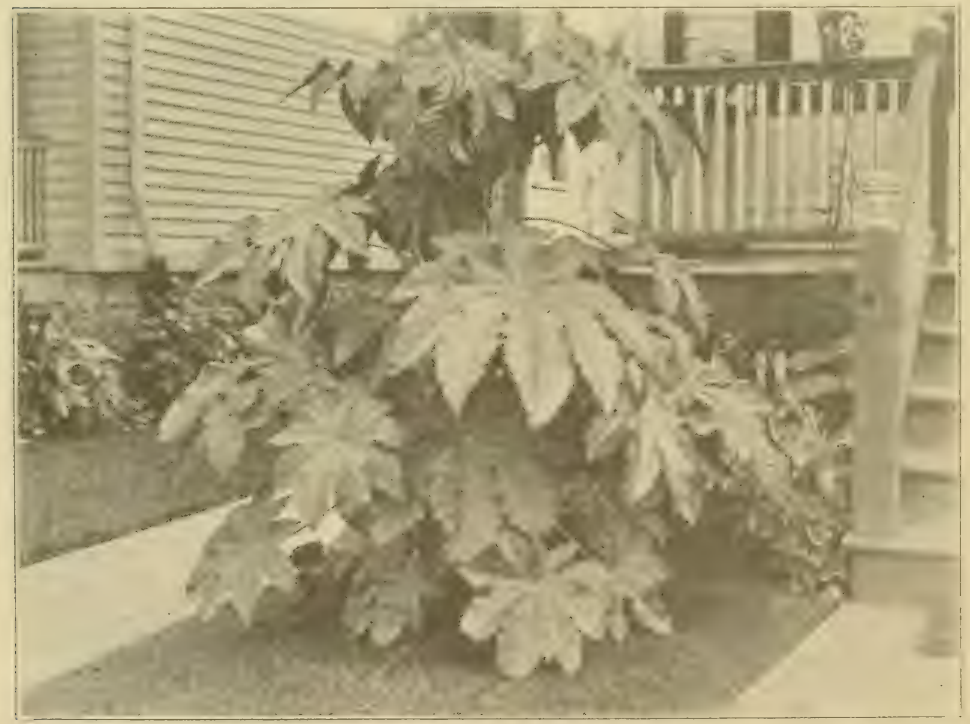

Fig. 18. - The showy Castor Bean plant-think of its being the product of a single seed! - fills more space than any other annual. 
because of their tall growth and ample leaves which are in the different varieties, purplish-red and maroon. The flowers and spiny fruits are not very showy. The plants range in height from 8 feet to 19 fowe

Ises. The Castor Bean is rather tropieal in appearanere and is useful for the esenter of large beds, for the batkeround of horders and in dense masses fo sereen unsightly buildings and fences.

Castor oil is obtained from the large seeds, which also contain an active poison. Children should be cautioned against biting into them.

Gulture. When starting them indoors the best method is to place several seeds in a small pot. When the seedlings have attained sufficient size, all but one should be pulled out. The seeds may also be sown in the open ground in which case they must be thinned to stand several feet apart. To make them grow tall give them an abundance of water and a mulch of manure.

\section{Celosia-Cockscomb}

Whoever has grown a few of the various Celosias has surely been charmed either by their beauty or their fantasy of form. Celosias are sometimes confused with Amaranthus, which, however, is coarser and of which the colors are not so clear.

The Sorts to Grow. Cockscomb (C. cristala). This species has huge, laterally flattened heads which in many cases really suggest the comb of a giant chanticleer. The colors range from crimson to golden yellow. Some plants often grow 2 feet tall while others are only 8 inches in height. (See fig. 19, page 40.)

Feathered Cockscomb (C. argentea or C. plumosa). The heads resemble ostrich plumes of shining, silky texture. Those of some sorts are a clear, brilliant pink or crimson; others are like feathers of pure gold. The plants when given space to develop will grow $21 / 2$ feet to 3 feet tall.

Woolflower (C. Childsii). Of rather recent development, the Chinese Woolflower is somewhat like the Feathered Cockscomb except that the flower heads form globular crimson masses resembling balls of woolen yarn or silk thread. The plants start to bloom when only several inches tall. Then branches develop, each tipped with a flower often from 4 inches to 6 inches in diameter. (See fig. 19, page 40 .)

UsEs. Huge masses of Celosias are showy in any annual border. The dwarfer sorts may be used to edge the taller Celosias or other annuals. The heads may be cut and kept in water for weeks. Some persons use them as everlasting flowers and keep them in their rooms 


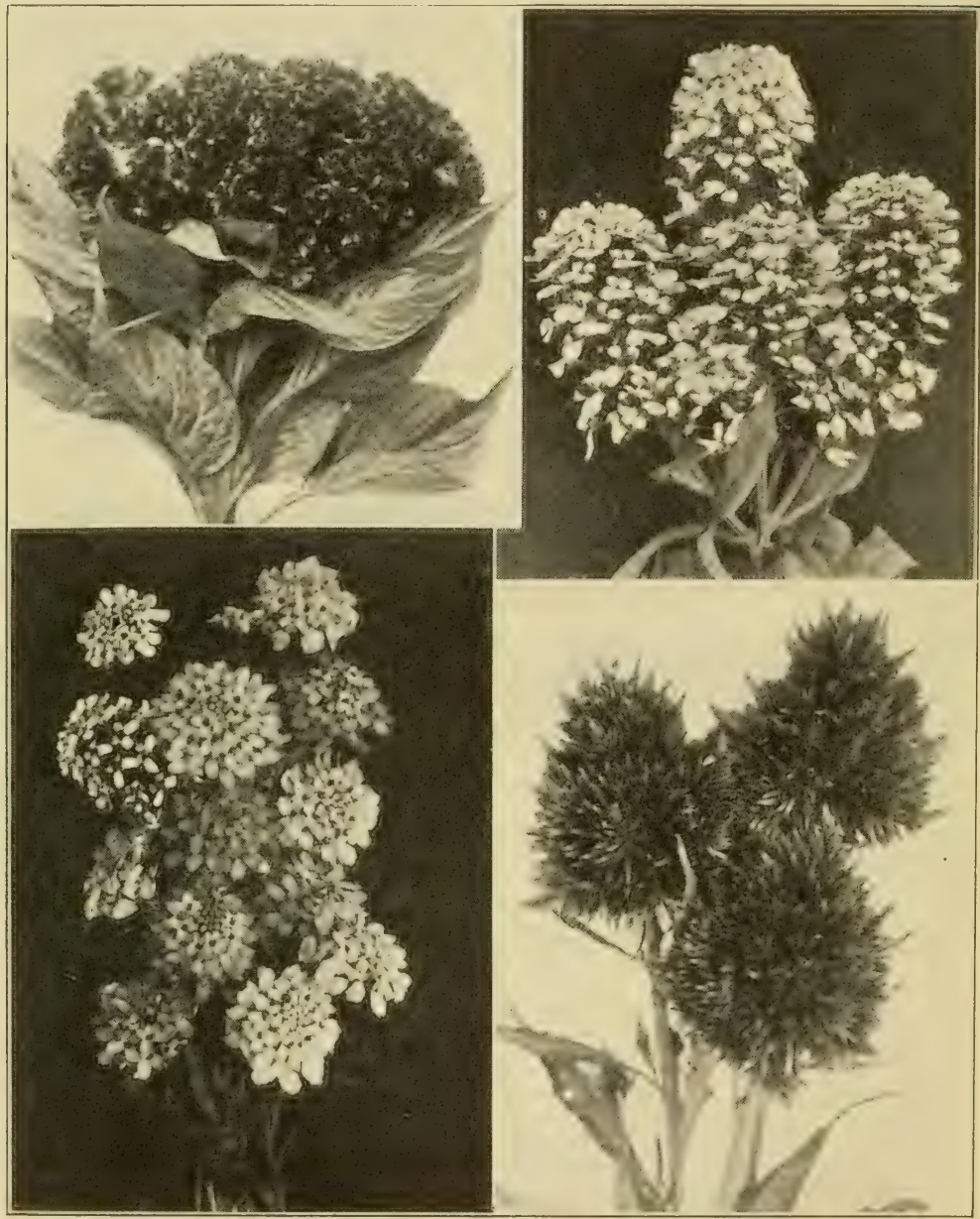

Fig. 19.-Upper left, a flower spike of the interesting Cockscomb; up?er right, the lovely white Candytuft (Iberis amara) louer left, I. umbellata, a species with flat flower heads in several colors; lower right, Woolflower blossoms resemble shaggy balls of silk or wool. 
all Winter. The wavy feathers of the Plumed Cockscombs are magnificent when well grown.

Culture. Sow the seeds either in a hotbed or window in March or April, or else sow in the open ground in May. Good soil should be used in planting Celosias for, unlike Amaranths, they respond to feeding. Farmers' Bulletin No. 1171 notes that transplanting into rich soil as the combs begin to form, makes the flower heads larger. The plants of the larger growing Feathered Cockscombs should stand at least 2 feet apart.

\section{Centaurea-Corn Flower and Sweet Sultan}

There are many kinds of Centaureas, both annuals and perennials, and not one but is either beautiful or interesting, or both.

Uses. First of all the Centaureas are attractive in the garden where their strong, upright growth and clean, lovely flowers attract us. As cut flowers they are lasting and lend themselves to vase arrangements. Sweet Sultans, when cut in bud, last for ten days. Corn Flowers are often sent as cut flowers from California to florists in the Eastern States. Blue Cornflowers are especially attractive when planted with the Golden Wave Calliopsis (page 36).

Species. Corn Flower. Bachelor's Button. Blue Bottle. Ragged Sailor. Bluet. This variously named plant is Centaurea cyanea. Its flowers are blue, purple, rose and white. The double form was introduced some 15 years ago and is the best sort to grow because the flowers are larger, fuller and more symmetrical. The plants are about 2 feet tall. Sow seeds in early Spring or even in late Fall. Allow 6 inches to 8 inches between plants; remember this and do not let the plants crowd each other. They flower in eight weeks from the sowing of the seed and the plants frequently self sow.

Sweet Sultan (C. moschata and C. imperialis). Many of the Sweet Sultans have a delicate fragrance. They are white, pink, yellow, lavender, purple and frequently have white or yellow centers. The outer florets are funnel-shaped and beautifully fringed. The flowers measure 3 inches or 4 inches across and are borne on strong stems. Some garden lovers whose soil lacks lime have not had the success they have wished for. The seedlings, although they stand transplanting nicely when small, are difficult to move later, unless lifted with a ball of soil. It is well to sow directly where they are to grow and thin them to stand 8 inches to 12 inches apart. (See fig. 20, next page.)

Basket Flower (C. americana). Although many of the Centaureas are large-flowering, the Basket Flowers are the giants among the 


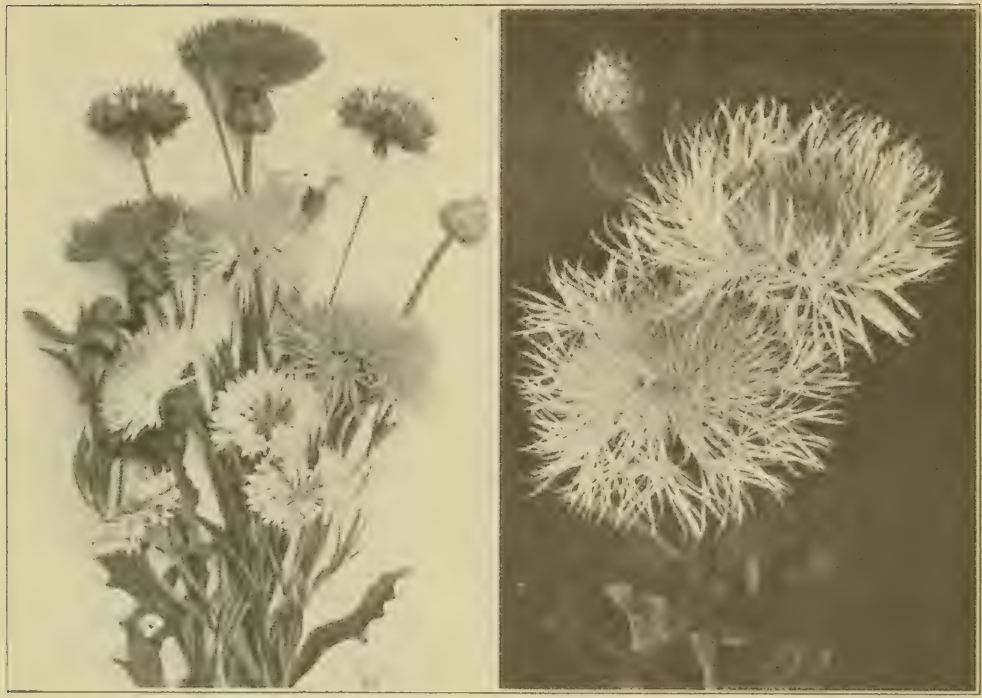

Fig. 20.-Lill. Sweet Sultans (the larger flowersi and Corn Flowers or Bachelor's Buttons; right, the Basket Flower, one of the true garden aristocrats.

annual forms. The flowers are thistle-like, $t$ inches in diameter, and rosy-lavender, and the plants srow 3 feet tall. Sieed is sown in the border and the plants are thinned to 12 inches. The plants prefer cool conditions and often suffer in the hottest summers.

\section{China Aster}

As the annual Asters differ from our wild Asters and were introduced from China, they should properly be known as China Asters. From a violet, Daisy-like flower with a yellow center, the China Aster has been bred to assume a multitude of forms and colors. Previous to 1890, the China Aster was not considered a cut flower, but was grown only for garden decoration. A few years later, with the production of the early sort, Queen of the Market, and the Comet and the Branching Asters, this flower began to exhibit its rapid development, its long stems, and its large flowers.

The principal types of China Aster popular for the garden fall into two groups: The flat rayed or "petal" Asters and the tubular or quilled Asters. Of these, the Tall Branching Asters, the Crego (an improved Comet), and the Ray are the most popular for cut flowers. but all the other groups -dwarf and tall -are interesting for the sar- 
den. Votiee figure 21, below, which illustrates some of the distinct types. Sored rataleges list mose of them in their various colers.

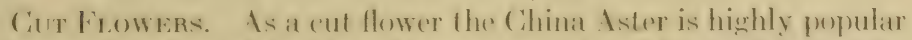
and generally admired for its colors - rose-poink, white, violed, purple. red, limht pink and lavender. It has splendid kerping qualities, but vase's used for it should be thoroughly cleaned afterward because of the odor which is usually generated hy Aster stems kept for a long time in water. It is well to remove all leaves from the part of the stem that will stand under water. A few drops of formaldehyde will keep the water from becoming foul. The stems are long and in most cases strong enough to hold the heary flowers erect. The flowers stand rough usage too, a quality greatly desired in hlooms used commercially. It is not difficult to raise Asters providing the soil is not infested with diseases.

Sowng. To have Asters in bloom reasonably early the seed should be sown in a sumny window or coldframe (see page go) in March. As before mentioned, Asters are often troubled with diseases, therefore, extra care is necessary in raising the seedlings. The late Geo. Arnold, originator of the branching type of Aster, was unusually successful with Asters of all kinds. Regarding the sowing of seeds, he writes that it is best to use a shallow box or flat. "Aster seedlings will grow in ordinary garden soil to a size large enough to transplant; but it is well

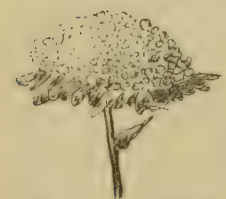

BALL UR QUILLED

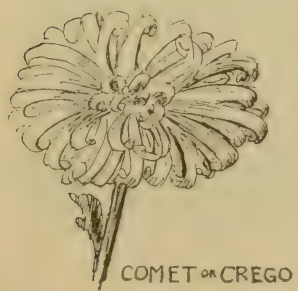

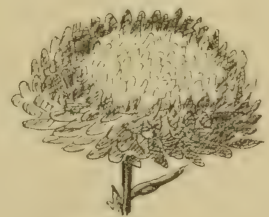

CROWN OR COCKADE

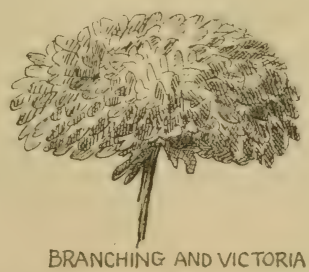

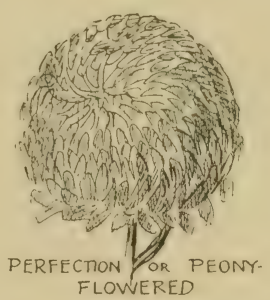

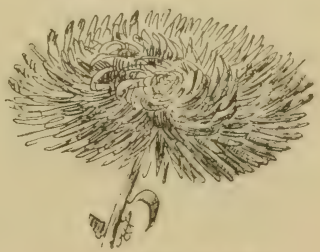

RAY OR KING

Fig, 21.-Types of China Asters. While all seed catalogs do not include all of them, they are well worth knowing and growing. 


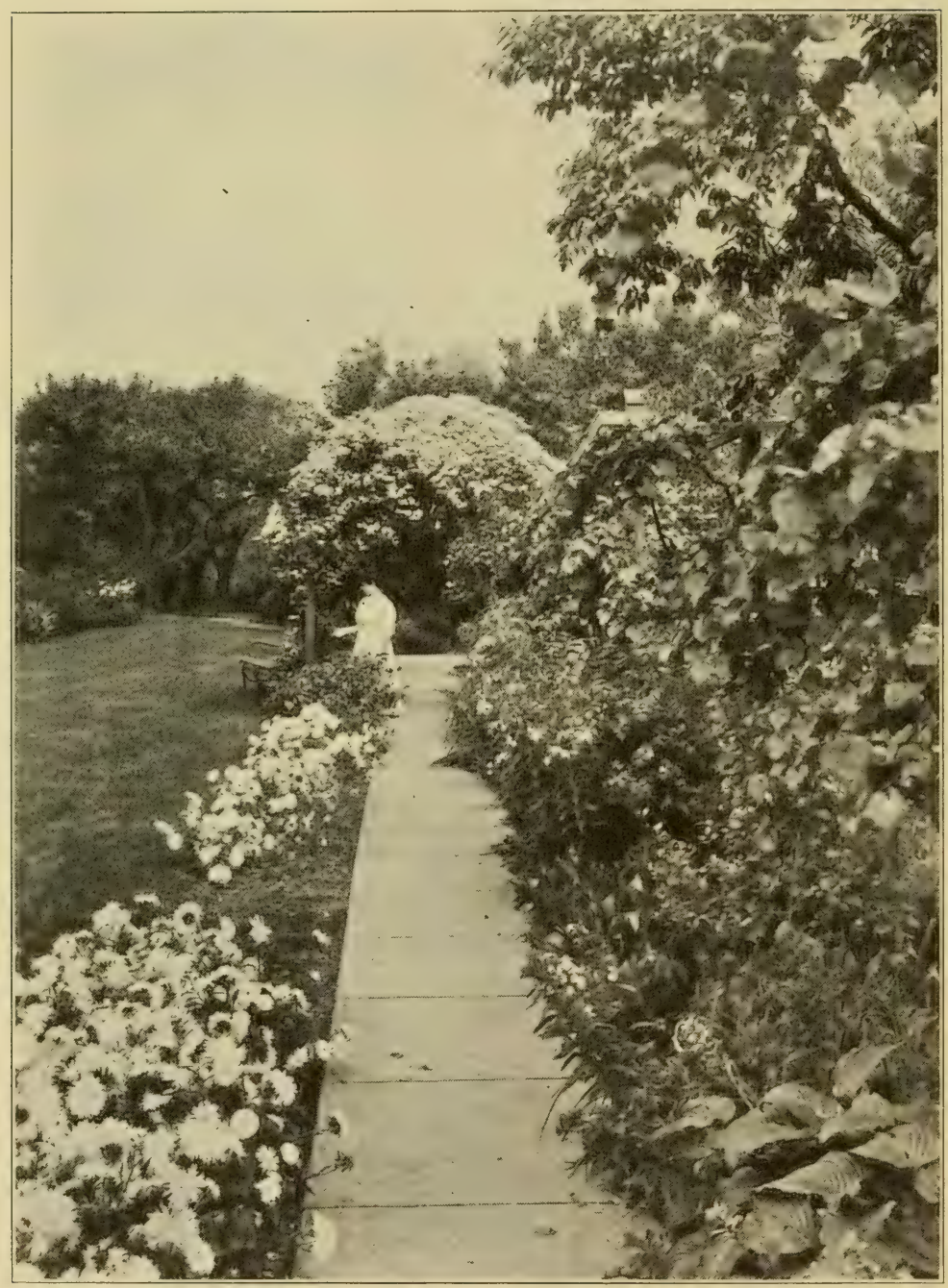

Fig. 22.-China Asters effectively placed along a garden walk. Note, also, the Japanese Clematis trained to form an arch. 
to add one-fourth well-rotted manure and enough sand to prevent the soil from becoming hard. Fill the flat half or two-thirds full, water thoroughly, and finish filling with soil just moist enough to handle nicely. The wet soil in the bottom will furnish enough moisture so that the boxes will not have to be sprinkled until after the seedlings are up. Sow the seed in rows 2 inches apart, cover with fine sand and press firmly." Note the advice to water before sowing the seed and to cover the seed with sand. Other suggestions as to seed sowing are found on pages 16 to 18.

Young Plants. The seeds will germinate in a little over a week and the seedlings should be kept in full light, so that they may be sturdy rather than tall and leggy. When they need water give it, but do not sprinkle the plants each day as this encourages the destructive dampingoff fungus. As soon as several true leaves have grown, the seedlings should be transplanted to other boxes. Use rich soil in the bottom of the flats and ordinary soil above as further protection against disease. Set the seedlings 2 to 3 inches apart. Crowding, too much water, or drought will check the plants, and nothing lessens the future blooming quality of the plants as much as a check. If the young plants are given a little cool air each day, or if a coldframe is available so that they may be gradually hardened off, they will stand some frost when finally set out into the garden.

The Plants in the Garden. The best soil for Asters is a sandy loam, but a heavy soil will also produce good flowers. If the spot where they are planted has been manured the previous year, it is better than to apply manure just before setting out the plants.

Set the plants at least a foot apart. Keep them cultivated and well watered. The feeding roots are usually near the surface of the soil so that cultivation should be shallow. A little shade is beneficial for their best growth.

Late Asters. Seed is sown in the open ground in April or May for late bloom. Choose the early varieties for early flowers and late varieties for this later sowing. If the plants are transplanted in hot weather it will be advantageous to "puddle" the roots. (See page 20).

Insect Enemies. Tarnished plant bug. The tarnished plant bug is so small that it would hardly seem able to do much damage, but it is the most serious Aster pest during the hot, dry weather. It punctures the growing tips of the plants so the growth is deformed and dwarfed. A tobacco spray and the dusting of the plants with air-slaked lime or tobacco dust is often moderately effective in keeping the bugs in check, but as they are rapid fliers they are seldom killed or com- 
pletely controlled. Mr. Arnold tells us that the bugrs do not work in the shade so that sometimes the plants are not troubled when srown under trees or cheesecloth screens.

Cuturms, grasshoppers, and blister beetles often do much damage. The former cuts the plant off at the surface of the soil. The two latter eat the flowers and foliate. Spraying with arsenate of lead will help to control them, as will alse a poison hait. The mest effective means of controlling the blister beetle is to jar the insects into a pan of herosene. They drop quickly as soon as they are touched or disturbed.

Root lice. Some sickly Asters are not discased but are affected with root liee which sap the strength of the plants, hut which may sometimes be controlled by tobaceo stems placed around the plants. It is not safe to plant Asters two successive years upon soil infested with these pests.

Diseases. Yellows. The peculiar yellowing of Aster plants is often due to faulty culture rather than to disease or improper moisture conditions in the soil. Vo means of control can be sugrgested except to keep the plants growing vigorously by cultivation. So far as the Massachusetts Agricultural College could find rut neither insects, discase. variety, transplanting nor weather is the cause.

Stem-rot. If the season has been a wet one the stems of Asters almost in the blooming stage often hecome black just at the surface of the soil. Gatrdens onee infered often hecome sol ad that it is hest mot to attempt to grow dsters in the m for several years. The spores are carried over from year lo yar. The seattering of wood ashes aboul the plants and the fumigating of the seed with a one per cent solution of formaldehyde have been reported as effective, lut other gardeners have found no satisfactory means of control.

Rust. Orange-colored masses of rust often appear on the under side of the leaves of plants which may thereby he either checked or stimulated into too active growth. Rusted plants of any sort are rarely curable; they must be pulled and burned. Spraying the young plants with Bordeaux mixture will prevent their infection. Note that the disease appears on the under side of the leaves; it is here only that spraying will be effective.

\section{Summary of Important Points.}

1. Carreful rullure from sered sow ing presents damping oft.

Q. Checking growth causes poor flowers and rust.

3. Shadine plants prevents injury from the tarnished plant hus.

4. If plants are hadly diseased, burn them and stop growing Asters for a few years. 


\section{Chrysanthemum, Annual}

The Annual Chrysanthemums are popular in England, but not well-known here although they grow nicely in the United States. They are variously known as "Painted Daisies" and "French Marguerites." The most popular sorts are Chrysanthemum coronarium and C. carinatum (tricolor). The former grows 3 feet tall and is typically yellow, either single or double. The latter grows but 2 feet tall and is usually white with characteristic rings of purple and yellow at the center. In both sorts the leaves are rather thicker than those of most other annuals.

UsE. These plants provide in the garden large masses of bloom which are interesting as cut flowers.

Gulture. The seed may be started as early as March in a hotbed or else sown directly in the open in April. Give the plants wellenriched soil and allow at least a foot between plants. To make them branch profusely they should be pinched.

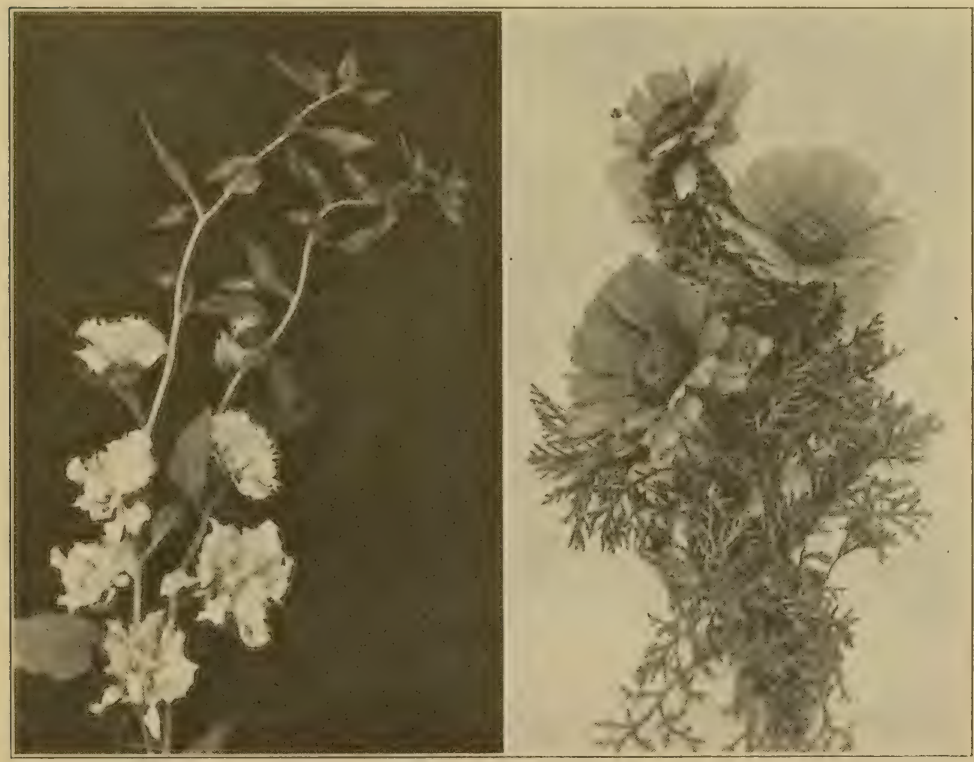

Fig. 23. - Left, Clarkia elegans, a flower of real beauty from the West; $;$ ight, whether for a garden effect, or for use in a vase, the Annual Chrysanthemums deserve more appreciation. 


\section{Clarkia}

This is a native of our western states and was first found by members of the Lewis-Clark Expedition. It was consequently named for Captain Clark. Two species are commonly cataloged: Clarkia elegans and $C$. pulchella. In the latter species the petals are three-lobed at the tips. The flowers are single and double and range from deep rose through lilac and light pink to white. The plants rarely grow over 2 feet tall, but bloom from July to October. (See fig. 23, page 47.)

UsEs. Clarkias are excellent for the annual border and for hanging baskets. Cut just before they bloom, the flowers open nicely in water. Helen R. Albee in "Hardy Plants for Cottage Gardens," accurately describes the appearance of the double varieties when she writes that they resemble sprays of Flowering Almond.

Culture. As Clarkias are hardy, sow the seeds out of doors early in the Spring. They thrive best on the sandier soils in either full sun or partial shade. Allow $\tau$ inches to 9 inches between plants. Some advise sowing in August and September and protecting the plants with leaves over Winter.

\section{Cleome-Giant Spider Flower}

Cleome pungens (spinosa or gigantea), grows 3 to 4 feet tall and is a most interesting garden subject. The four-petalled flowers are pinkish-lavender and white and are given a peculiar, airy appearance by the long-stemmed stamens and pistils which protrude from the flowers for several inches. The plants have a peculiar odor, hence the name pungens. Fig. 24 shows a flower spike and the nature of the flowers, seed pods and leaves. The stems are more crowded with flowers than shown in the sketch.

UsE. Although rather coarse, Cleomes are useful for planting in beds as substitutes for shrubs or where other bold masses of ornamentals have failed. In a small garden two or three plants would be sufficient. The color is apt to clash with the clear pink of some other sorts, wherefore it is often best to grow the white variety.

Culture. Sow the seed in the open ground (preferably sandy soil) when it becomes warm in the Spring. Give each plant at least two feet in which to develop. If the plants show an inclination to fall over they should be staked. 


\section{Cosmos}

The Cosmos is not as impatient about coming into bloom as most annuals, but waits until it has made its growth before expending its energy in flower production. There is no other tall annual so graceful or so useful as the Cosmos. Ordinary Cosmos as well as some of the finer varieties is so late that in some sections the frost kills the plants just when the first few flowers have opened. There are, however, sorts cataloged as Extra Early Cosmos, which, though not as tall as the other sorts, bloom in July and August rather than in October.

In recent years the Double or Crested Cosmos has been introduced. In this the flowers are frequently entirely double or else the disk-florets become tufted or crested. There are good varieties in each of the three colors - white, pink, and crimson. The plants bloom late, and many may not produce double flowers, for as yet, the type is not fixed. Nevertheless, we are pleased with the few we do get. The leaves of these sorts are less finely divided and may be distinguished even in the seedling stage.

Forms of C. sulphureus are sometimes listed in catalogs. This is a yellow sort and would be more cultivated did it bloom earlier. It is suggested that this type be started early and planted in boxes so that the roots are confined.
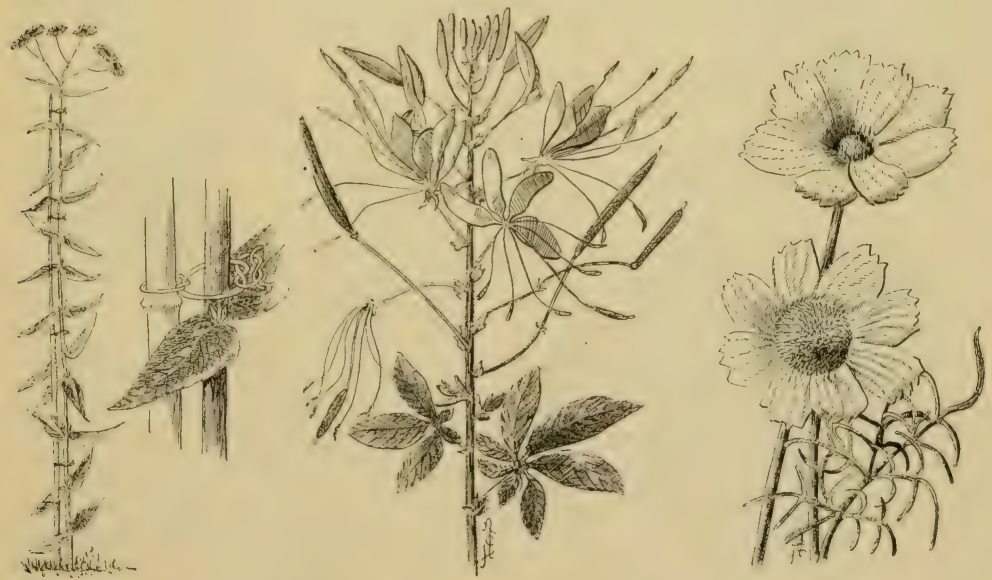

Fig. 24.- Left, how to tie tall plants to stakes. Note that the cord is tied to the stake first so that it cannot slip down and so it need not be pulled tight enough to choke the stem; center, Giant Spider Flower, a unique subject for use at the back for a mass; right, Cosmos, showing both the single and the crested types. 
Uses. Cosmos serves our need for a tall, beautiful annual to supply us with flowers for our homes. The stems are long and the flowers keep in water from five to seven days. No garden should be without at least a few plants.

Culture. The late sorts, and especially the Double and Crested varieties, should be sown in a hotbed or sunny window in March. In the sections where Cosmos self sows there is little difficulty in getting blooms. Planting Cosmos in boxes will hasten its blooming season.

Some sections of the country report that mildew attacks Cosmos. Should this be troublesome the plants may be dusted with sulphur which will not discolor the foliage as would the equally effective Bordeaux mixture.

Often it is well to stake the tall plants because the brittle branches break off easily. Furthermore, plants in need of staking bear many of their flowers on crooked stems. (See fig. 24, page 49.)

\section{Datura-Trumpet Flower}

These large-flowered annuals are related to the common Jimson weed. Their flowers are trumpet-shaped, white, purple, or yellow in color, and sometimes six inches long. Datura fastuosa (Cornucopia) is the common white species. The flowers are often much doubled, in which case they are mere monstrosities. The outside of the petals is frequently washed with an objectionable purple color. The yellow sorts, are no doubt, forms of $D$. chlorantha, a tender perennial. Both of the above species are delightfully fragrant. The plants grow two to three feet tall and spread out equally wide. (See fig. 26, page 5.)

Culture. Sow the seeds indoors or in the border. Allow each plant $1 \frac{1}{2}$ feet on all sides.

\section{Didiscus or Trachymene-Blue Lace Flower}

Several years ago the Blue Lace Flower was brought back to light after many years of neglect. It is still a novelty, however, and does not always succeed as well as the old standbys. The flower heads are made up of small, azure flowers produced in umbels like those of the Wild Carrot. The stems are somewhat hairy and grow two feet tall. The plants flower during July and August. (See fig. 25.)

UsEs. This flower is better for cutting than for garden ornament, as the plants are not particularly showy. Arranged in a vase with small foliage, the blooms display their charms to advantage.

Culture. Sow the seed in pots or flats indoors or in a hothed in March. Give each plant a foot of space in the garden. 


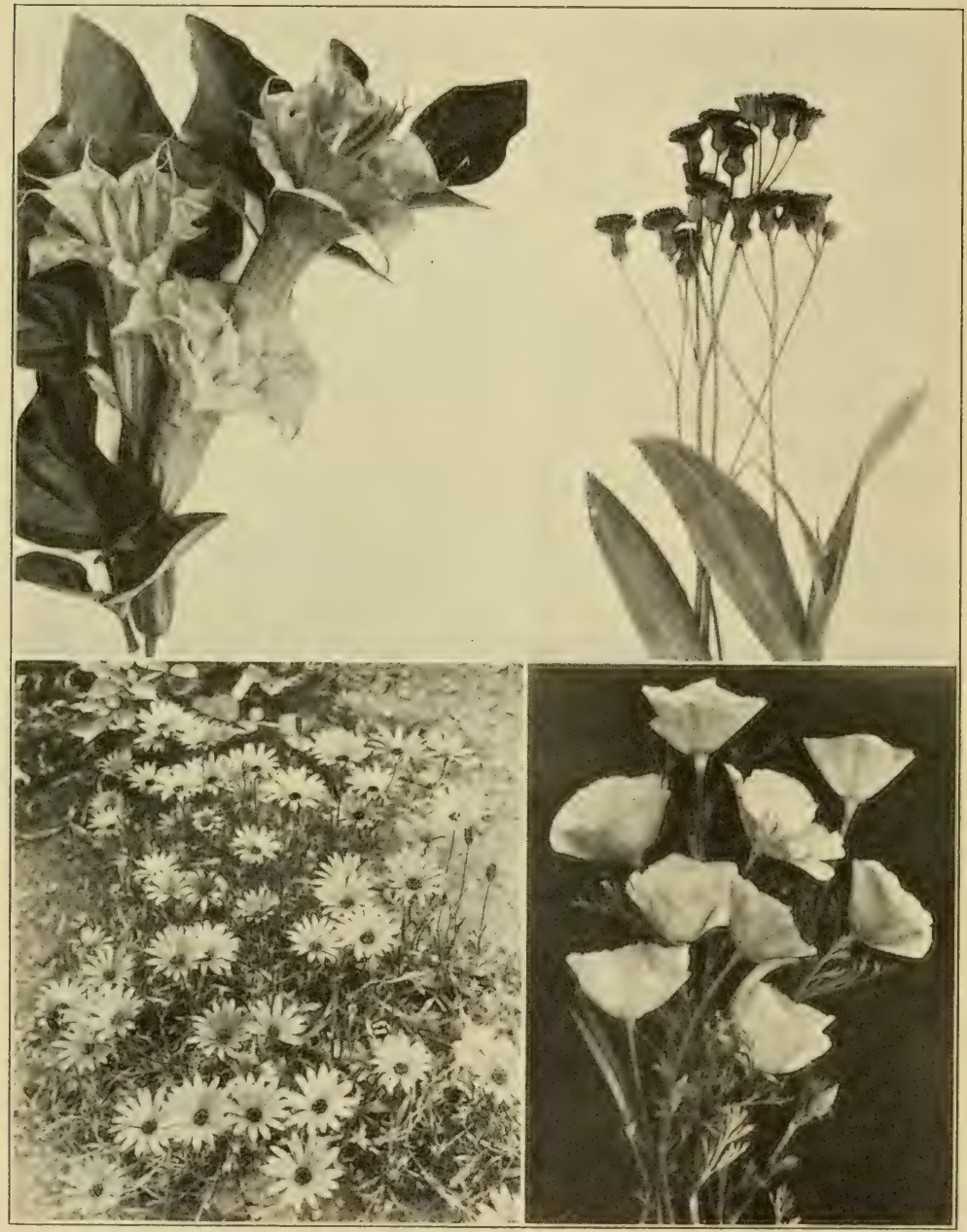

Fig. 26. - L have greater beauty; upper ripht, the brilliant, tassel-like flowers of Flora's Paint Brush are worth cultivating; lover left, showing the charm of the African Orange Daisy; lower right, California Poppies are a delight for hot, dry places 
Gulture. This is simple. Sow the seeds in the horder early in the Spring and thin the plants so that they stand four inches apart.

\section{Eschscholtzia--California Poppy}

The silky, golden-yellow blossoms of this, the State flower of California, are borne in profusion. Gardeners have greatly improved the plant until now we have both singles and doubles in a great range of colors-creamy-white, carmine, deep pink, orange, lemon and coralpink. Some forms have delicately fluted petals. The California Poppy spreads over the ground, but also grows about a foot tall. The leaves are greyish-green, and add much to the simple beauty of these flowers which appear profusely from June until frost. (See fig. 26.)

Uses. These flowers can well be planted in masses in beds or in a border; as the various colors harmonize nicely, the varieties may be mixed. If the buds are cut before they are quite open, the flowers may be used in the home to advantage. In the garden the golden and lemon varieties combine nicely with such blue materials as the Bachelor's Button and the Larkspur.

Culture. Sow the seed in the Fall, or as early in the Spring as the soil can be worked. Thin the plants to stand eight inches apart. Do not attempt to transplant, as the Poppy does not move readily. The old plants will self sow if protected in the Fall.

\section{Euphorbia-Spurge}

This is an interesting genus of plants which give off a milky juice when any part is bruised or broken. The upper leaves are in many cases showy, while the flowers are inconspicuous. It is to this group of plants that the popular Christmas Poinsettia belongs.

Specres. The Mexican Fire Plant, Painted Leaf, Annual Poinsettia, or Fire-on-the-Mountain. (Euphorbia heterophylla). This plant has deep green foliage until the middle of Summer when the top leaves turn scarlet either all over or merely at the base. When the plants are growing well, they become much branched and exceedingly handsome. They attain a height of two or three feet.

Snow-on-the-Mountain. Variegated Spurge. (E. marginata or variegata). This species is wild in the United States from the Dakotas to Texas and eastward. The leaves are oval, the upper ones being margined with white. The flowers are less showy than the leaves. The plants grow two to three feet high. 
Uses. Both the Mexican Fire Plant and the Snow-on-the-Mountain are useful in a border of annuals. Their oddly colored leaves are sure to attract attention. The latter mentioned sort branches at the height of about a foot and a half, so that when it should be most showy, it is often bare at the base. However, any other annual growing about two feet tall may be planted in front in order to hide the bare stems. We might suggest for this French Marigolds.

Gulture. Both species prefer heat and full sunshine, but they will grow in rather poor soil. Sow the seeds of the Mexican Fire Plant when danger from frost is passed. It is best to sow three or four seeds in a place, and when the seedlings appear, to pull up all but one, as the plants need a space of 18 inches to develop in. The Snow-on-theMountain is perfectly hardy, and the seeds may be sown very early in Spring. In some localities it behaves as a perennial and sprouts up each Spring. It also self sows readily.

\section{Four o'Clock or Marvel of Peru-Mirabilis}

The Four o'Clocks are well known and were favorites with our grandmothers, just as they are admired by us today. The flowers remain closed until late afternoon, hence the name Four o'Clock. They are white, crimson, violet, yellow and striped. The plants are two feet tall, and during a season produce hundreds of blooms, starting in late Summer and continuing until cut down by frost. (See fig. 25, page 51.)

UsES. Four o'Clocks are useful for temporary hedges between the flower and regetable gardens. A few plants will fill the bare spaces found, in so many cases, between the house foundations and the walk leading to the backyard. In beds by themselves they are also attractive.

Gulture. The plants often self sow. Otherwise sow the seeds thinly in the row where they are to grow as soon as danger from frost is passed, or else start them earlier in a sunny window or hotbed, and plant out when the trees are in leaf, setting them one to two feet apart. The plants produce rather tuberous roots which may be dug and stored over Winter.

\section{Gaillardia-Blanket Flower}

The bright, sunset colors of the Blanket Flower are an asset in any garden. There are annual and perennial Gaillardias, and the various species have been blended to such a degree that it is difficult to say just which are which. Generally the perennials are yellow and 
the annuals red, with tubular florets, but the various colors and forms grade into one another. (See fig. 25, page 51.)

The plants grow one and onc-half feet tall, and bloom from early Summer till late Fall, producing a wealth of long-stemmed flowers. The two annual species from which the garden varieties are derived are: G. amblyodon, in which the rays are brownish-red throughout their length, and G. pulchella, in which the rays are yellow at the tips and rosy-purple at the base. G. picta and G. Lorenziana are varieties of the latter species. In G. Lorenziana, all or part of the florets are quilled.

UsE. Gaillardias are excellent for beds, borders and for use as cut flowers.

Gulture. Gaillardias prefer full sunlight and a porous, welldrained soil. The seed may be sown early in the Spring in the border where the plants are to grow, or started in a hotbed or sunny window. Thin the plants to stand at least a foot apart.

\section{Godetia-Satin Flower}

Closely related to the Evening Primroses, the Godetias are deserving of greater attention. The flowers open wide and are of a satiny texture. Varieties may be had in rose and white, scarlet, dark crimson and pure white. Usually a deeper color is found near the center of the flower, as if painted upon the petals. (See fig. 27, page 56.)

Two species are common: Godetia amœna, known as Farewell-toSpring, grows one to two feet tall; the flowers are arranged up and down along the stems, and resemble in their double form those of the double Clarkia. G. grandiflora, the more popular species, grows only 6 to 12 inches tall, the flowers being in a compact mass, and three to four inches in diameter. They bloom from June to October.

UsE. Godetias are always attractive in the garden and noticeable because of the interesting texture of the flowers. They may be grown in pots.

Culture. Sowing the seeds in a frame or sunny window will hasten the blooming time. The plants succeed in poor soil and sandy spots; in fact, it is said that they produce leaves instead of flowers when planted in rich soil.

They will also grow in partial shade. Let the plants stand at least a foot apart, for if too crowded they grow leggy, and are weakened. They self sow in the warmer climates. 


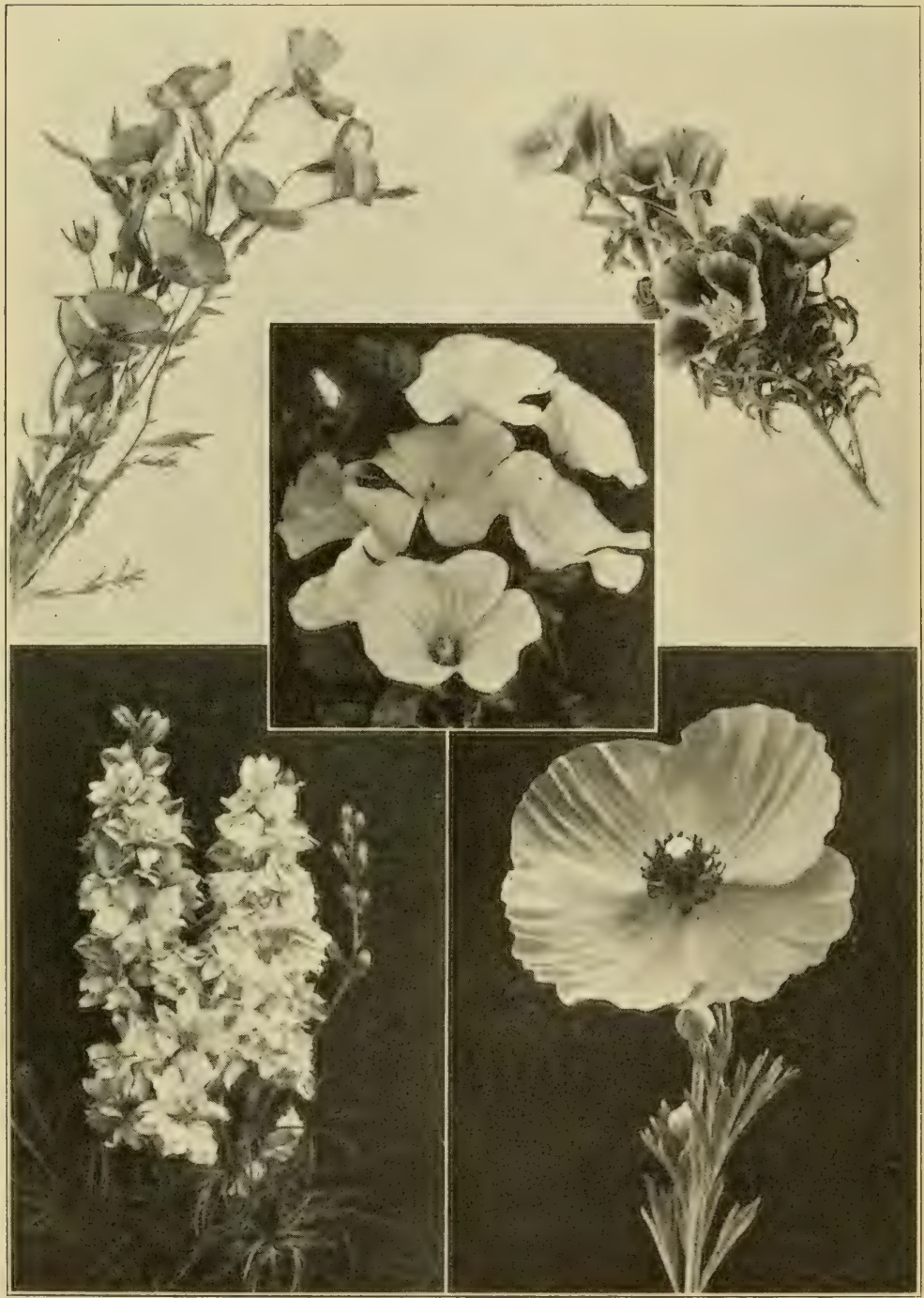

Fig. 27.- Upper left, Scarlet Flax is showy and almost glistens in the sunshine; upper right, Godetia, with its satiny petals; lower left, spikes of the Rocket-flowered Larkspur; lower right, Hunnemannia, a Poppy useful for both garden and dwelling; center, Lavatera, one of the handsomest of the Mallows for the border. 


\section{Gypsophila-Baby's Breath}

This is one of the smallest, daintiest flowers of the garden. Two species are commonly grown: Gypsophila elegans and $G$. muralis, both of which grow one and one-half feet tall, and bear tiny white, pink, and rose-colored flowers upon fine, wiry, much-branched stems.

Uses. In the garden, Gypsophila produces a misty appearance wherever it is planted. These flowers can be used to good effect planted at frequent intervals in front of and among other annuals, such as Larkspur, Poppies, Lupines, etc. They also make a good carpet for Gladioli and other Summer-blooming bulbs. As cut flowers, they combine handsomely with Sweet Peas and such flowers as need a little foliage to set them off. In arranging flowers with Baby's Breath, do not use too much or the result will have a "fussy," too-dressed-up appearance.

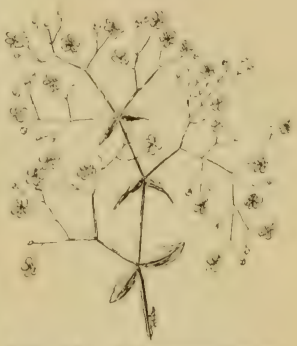

Fig. 28.-Gypsophila, a dainty, almost indispensable flower.

Culture. The name Gypsophila means gypsum-loving, these plants preferring limestone soils. The flowers bloom in six weeks from seed sowing, and have but a short blossoming season, for after three weeks they produce their seed and stop flowering. Seed should therefore be sown every two or three weeks for a succession of bloom. Some of the seed dropped by the first crop of blossoms will often flower during the season. Thin the plants to stand 8 to 12 inches apart.

\section{Hibiscus-Marshmallow}

There are shrubby, herbaceous, perennial and annual Marshmal lows, but in this book we shall mention only the annual sorts. $H$. trionum (africanus) grows two feet tall and its branches are inclined to creep over the soil. The flowers are yellow or white, with a brown or purple eye, one to three inches in diameter, and are called by various names such as Flower-of-an-Hour and Trailing Hollyhock. They open only in full sunlight. H. Manihot, the Sunset Hibiscus, has yellow flowers four inches in diameter with maroon blotches and leaves deeply cut into six or eight lobes. The plants grow at least four feet tall.

Uses. Of the two species mentioned the Sunset Hibiscus is the better. It is attractive in the border and resembles the perennial Marvel Mallows. The Flower-of-an-Hour sometimes becomes a weed in rich soil. 
Gulture. The seeds of $H$. Manihot must be sown in a sunny window, or hotbed early in the season else the plants will not bloom hefore frost. Sometimes, however, the plants are perennial.

\section{Hunnemannia--Giant Yellow Tulip Poppy or Bush Eschscholtzia}

Despite its long name, this plant is well worth growing. The bright, yellow flowers of $H$. fumariæfolia are like those of California Poppies except that they are more crinkled, and of greater substance. The leaves are glaucous and thick, but finely cut. The plants grow two feet tall and bloom in September and October. (See fig. 27, page 56.)

UsEs. Hunnemannias are handsome garden subjects under any conditions. Sown in a bed with Nigella (p. 6\%), they offer a pleasing contrast. The flowers are good keepers when cut in the bud, lasting a week in the home. They are attractive combined with Baby's Breath.

Gulture. As with all the Poppies, Hunnemannia seedlings are hard to transplant except just after germinating and when taken with a ball of soil. It is best to sow the seed in May where the plants are to grow, thinning them to stand 8 to 10 inches apart. If early results are desired, start the plants in small pots and shift them carefully to larger ones when necessary. Some persons have had difficulty getting the seed to grow, but germination can usually be assured by coaking the seed. Plants withstand drought and prefer full sunlight.

\section{Larkspur-Delphinium}

The Annual Delphinium is one of the best known annuals, and has undergone great improvement in its colors and the fullness of its spikes. The colors range from white to carmine, light pink, scarlet, light blue, and dark purple. (See fig. 27, page 56.)

There are two main types. Those varieties derived from Delphinium ajacis are known as Rocket- or Hyacinth-flowered because they produce long trusses of bloom, but few side branches. Varieties of $D$. consolida are called Candelabrum because they branch freely and bear a mass of bloom on many stems. The double varieties of both groups are refined in form, and should be more grown. Many of the sorts grow two feet or more in height.

Uses. Larkspurs provide bright, cheery masses in the border from early in the Summer until frozen in the Fall. The clear colors can be more readily obtained in the annual than in the perennial sorts. 
The flowers are easy to arrange gracefully in vases, and as they keep well, they are most acceptable as cut flowers.

Gulture. Seed may be sown either early in Spring or in the Fall. The plants are perfectly hardy and often self sow. As they grow, thin them out to stand 8 to 12 inches apart.

\section{Lavatera-Annual Mallow}

The name Mallow is applied to a number of plants of various habits, all of which bear flowers that resemble Hollyhocks. The common annual Lavatera is L. trimestris, with blossoms of a very bright shrimp pink two and one-half to three inches in diameter. The white flowered varieties are also attractive. The plants produce flowers freely from July to September, and are two and one-half feet tall.

UsES. As border subjects they are handsome. They are also said to be good cut flowers. (See fig. 27, page 56.)

Gulture. Lavateras prefer light soil, sun and plenty of water. Sow the seed in May, where the plants are to grow. Later, give each plant two feet of space to develop in.

\section{Linum-Flax}

There are several annual Flaxes, including Linum grandiflorum var. coccineum, the Scarlet Flax, about a foot tall, with wide-open, glossy flowers, and L. usitatissimum, the Flax of commerce which bears blue flowers, and grows three feet tall.

Uses. The Scarlet Flax is truly beautiful and forms clumps in the border where the glowing flowers are a delight of gracefulness. It is also an excellent edging plant. (See fig. 27, page 56.)

Commercial Flax has been grown for many years and has escaped from the cultivated fields of many countries, and become wild. The species name, usitatissimum, means most useful and refers to the various parts which have been used. It was a source of cloth before the foundation of Babylon. The Egyptian mummies are wrapped in linen made from fibers obtained from the stems of this species. In the early days of its cultivation the plants were cut and soaked in water to dissolve out the gummy substance between the bark and stems. After drying, the stems were crushed by rollers and then beaten with broadswords. The fibers were then spun into threads. The Romans used linen for cords and sails, but not for garments. Linseed oil is made from the seeds, as well as flaxseed poultices and tea, well known home remedies. Some persons believe that a flaxseed placed in the eye will help to remove other foreign substances. 


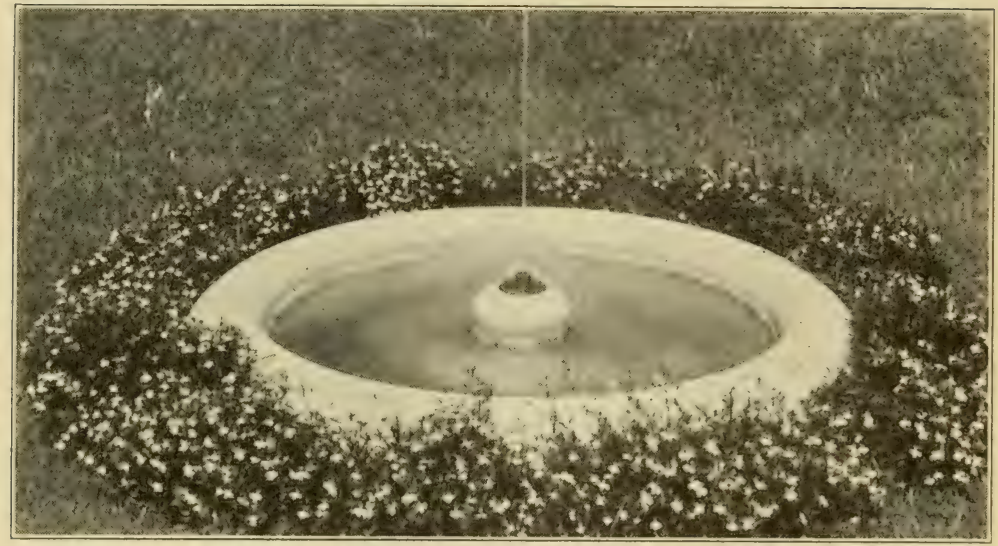

Fig. 29. - An attractive edging of the dwarf, upright type of Lobelia appropriately used to border a fountain.

Culture. Seed of Scarlet Flax is perfectly hardy and may be sown early in the Spring. Thin the plants to stand 8 to 12 inches apart. A succession of bloom is attained by sowing additional seed several times during the Summer.

\section{Lobelia}

Clear blues are found among the annual Lobelias. The varieties of Lobelia Erinus, the common species, are of two sorts-those which produce compact plants four inches tall, and trailing forms, which hang down for two or three feet over the sides of a pot. The flowers are tiny, deep or pale, white and blue, and are produced in great abundance. The foliage of the deep blue sorts is also dark and bluish in color.

Uses. The dwarf sorts provide one of the best blue annuals for edging beds of other flowers. The trailing sorts are attractive for hanging baskets, vases and window boxes.

Culture. The Lobelia though moderately successful in most parts of the United States, is at its best in the cooler regions, where the Summers are not too hot. Sow the seed in March, or earlier, indoors; it is very fine and should be carefully handled. Transplant the young plants when very small. In the garden the plants should stand six to eight inches apart. Lobelias are successfully raised from slips which, if taken in the Fall, will give flowering plants for the Winter window garden. 


\section{Lupines}

Lapines are attractive plants bearing Pea-like flowers in long, graceful spikes. There are annual and perennial species. The annual varieties are mainly derived from the following species: Lupinus luteus, in which the flowers are yellow and the stems hairy; $L$. hirsutus, a blueflowered sort, very hairy; and L. Hartwegii, a two-colored species with blue and red, or blue and white flowers. The Lupines bloom during the Summer, and grow two to three feet tall. The leaves are seven- to nine-parted, and are a handsome feature of the plants.

Uses. As a border plant the Lupine is quite interesting; cut, its flowers are exquisitely suitable for graceful bowl arrangements.

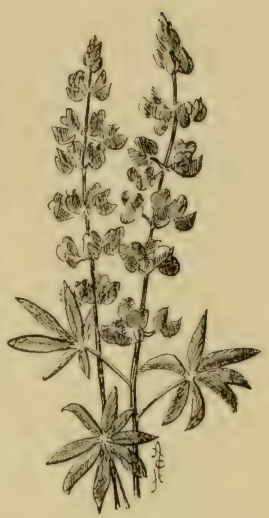

Fig. $30 .-$ Lup ine spikes make dainty cut flowers.

Gulture. Do not transplant Lupines. Sow them in small pots in April (see page 22), or in the open border in May. They bloom in eight weeks from seed. Let the plants stand a foot apart. Being legumes they improve poor soil. Plant them in partial shade. If the soil is rich, they will grow three feet high, and need staking. Remove the fading flowers to prevent them from going to seed; this will also cause the other buds to open larger.

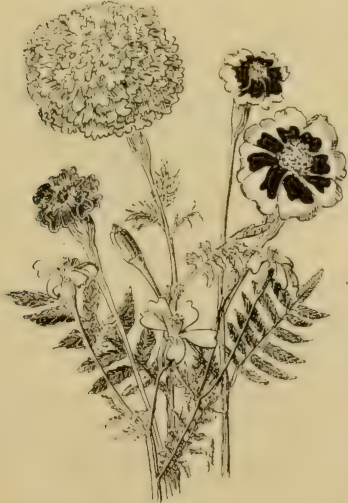

Fig.31.-Threekindsof Marigolds: African (the largest); Mexican (the small one); and French (with marked petals).

\section{Marigold-Tagetes}

Even the name-Mary's Gold-captivates us, and what could be more appropriate? The flowers of these old, old favorites are in some varieties veritably made of flakes of gold. How easy it is to be wealthy with Mary's Gold!

Kinds to Grow. The African Marigold ( $T$. erecta) has large balls of petalssome golden and some lemon-that are universally admired. Stiff and formal though they are, they will always be favorites. They grow two and one-half feet tall.

The French Marigold (T. patula) is typically golden and lemon, but its 
flowers are often marked with crimson and maroon. They are smaller than in the other species, and the plants are more dwarf, growing only a foot tall.

The Mexican Marigold (T. signata pumila) is a compact, bushy sort with finely-cut leaves and golden-yellow, star-like flowers of great brilliance.

Uses. The African Marigolds are a bold addition in the background of the border and in large beds. The French and Mexican forms are excellent edging plants, their shining flowers appearing to good advantage. All three are useful for cut flowers, because of their good keeping qualities and stiff stems. A favorite combination for the table is Marigolds and Larkspur. When most other flowering plants are becoming dry and brown in the Fall, the Marigolds show up in all their brilliance. Must we add, for the sake of truth, that the plants have a peculiar odor which is offensive to some persons?

Gulture. Marigolds, being perfectly hardy, can be sown in a warm spot very early in the Spring. They will stand transplanting nicely. Set all three sorts 18 inches apart, for the dwarf sorts branch profusely. They prefer the lighter soils and a sunny exposure, but are adaptable to less favorable places.

In saving seed from our own plants it is wise to pull up such as do not meet our ideals, allowing only the best to set seed.

\section{Mesembryanthemum-Ice Plant or Fig Marigold}

The Ice Plant (M. crystallinum) is the most commonly grown representative of this genus. It is a curious plant with thick leaves covered with glistening dots, or "ice-like globules." The flowers are white or light rose, but not showy. The plants are trailing and seldom more than six inches tall.

There are many other Fig Marigolds, of which $M$. pyropeum (cataloged as $M$. tricolor) is a most attractive annual. The flowers are crimson, pink, and white, and an inch and a half or two inches across. The plants are trailing and grow six inches tall.

Uses. These plants are useful for rough spots in the garden, where the soil is dry and the sun is very hot. They are used for edging.

Culture. The seeds should be sown either indoors in April, or in the open border when the soil is warm. They require very little water. 


\section{Mignonette-Reseda}

The sweet fragrance of Mignonette, or Little Darling, is a luxury in any garden. "Its sweetness wins all hearts." Its Latin name Reseda means "to calm or appease," and refers to the fact that the plant was employed by the Romans in treating bruises. Some of the Mignonettes produce large trusses of bloom eight inches long and two inches in diameter, while other sorts have much smaller trusses. Generally, the smaller flowered sorts are more fragrant than the giant forms. The flowers are brownish-red or white, and individually are odd in form.

USE. The fragrance of Mignonette suggests many uses, for it renders any bouquet delightful. As a cut flower, some varieties last fully a week in water. Grown in pots for the sunny window, the flowers are a constant delight.

Gulture. Sow the seed in the open soil and thin the plants to stand eight inches apart. The Mignonette is intolerant of being transplanted, and if it must be moved, this should only be done when a ball of moist soil is taken with the seedling. If one wishes to encourage long spikes and long stems, the plants should be disbudded so that only a few shoots are allowed to grow. It is often best to give the plants a dressing of bonemeal early in

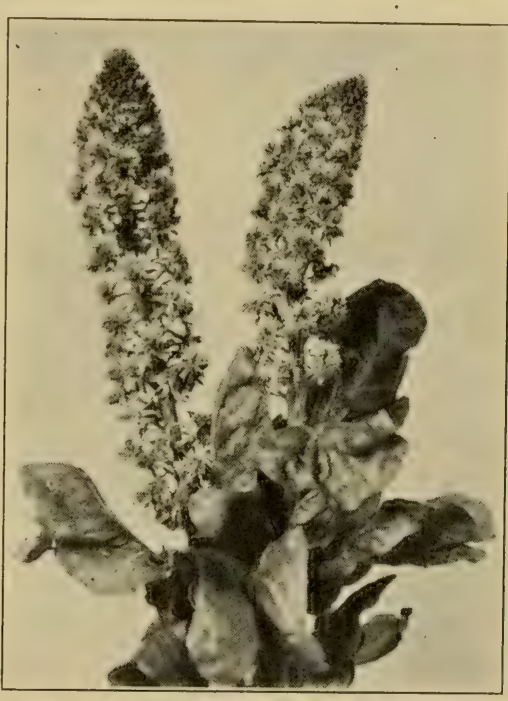

Fig. 32.-Mignonette- "its sweetness wins all hearts." the season, in order that they may have plenty of plant food available. A watering with liquid manure when in bud is beneficial. Sowing seeds several times during the season will prolong the blooming period.

The plants grow best during the cool weather of Spring and Fall, and it is from the Fall plants that the best blooms are obtained. On light soils the fragrance is said to be stronger than on heavy soils, but the growth is not as tall nor are the spikes as long. 


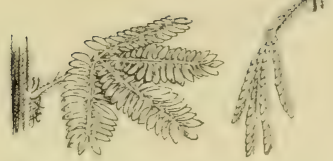

Fig. 33.- Sensitive Plant leaves; at the left before, and at the right after being touched

When pot-grown, ten or twelve seeds are sown in each pot, and the plants thinned so that but two or three remain.

\section{Mimosa-Sensitive Plant}

Sensitive Plants are grown not for their beauty, but for their interesting qualities. The many-parted, Locust-like leaves are sensitive; when touched the leaflets fold together, and finally the entire petiole droops. After a few hours the leaves assume their normal appearance.

The plants are natives of dry regions where, when a drought is felt, the leaves fold and thereby reduce the leaf surface exposed to the drying effect of the air. The common sensitive plant is Mimosa pudica, a thorny sort, bearing fuzzy pink flowers. Either dry or cold conditions cause its leaves to close.

Culture. Sow the seeds in shallow boxes and transplant in late May to a hot, dry place in the border.

\section{Mimulus-Monkey Flower}

The flowers of this interesting genus are curiously shaped and spotted with contrasting colors. Those generally seen are bright yellow, spotted with maroon, red or orange. Mimulus moschatus is the Musk Plant, so-called, because of its musk-scented leaves. It is really a trailing perennial with yellow flowers, but it can be grown as an annual. M.luteus, variously called in catalogs, tigrinus, cardinalis, and grandiflorus, is a largeflowered sort with yellow, gaudilyspotted blossoms. Both sorts grow a foot tall.

UsEs. Both Monkey Flower and Musk Plant are grown for their brilliance of color, which is attractive, though not truly beautiful.

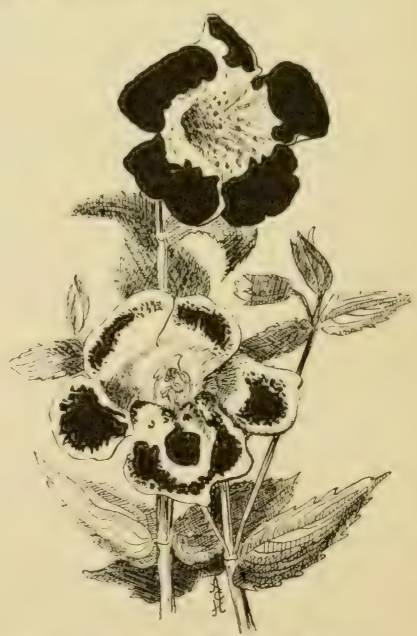

Fig. 34.-The Monkey Flower, though bizarre, is well worth planting. 
They are effective planted in hanging baskets or in the border where the soil is moist.

Culture. As the seed is very small, the plants had best be started indoors fairly early in the Spring. Keep the seed pans constantly moist, but not wet. Transplant the seedlings when quite small, in tiny clumps and thin them out later. Transplant to the open only when the soil is warm. These plants prefer partial shade and, as stated above, like moisture. Some housewives who grow the Musk Plant for Winter bloom, stand the pots in a dish of water.

The Monkey Flowers may be increased by cuttings. Take slips of the young growth and place several in a small pot of sandy soil. Shortly they will root. When they begin to crowd they may be repotted into larger pots.

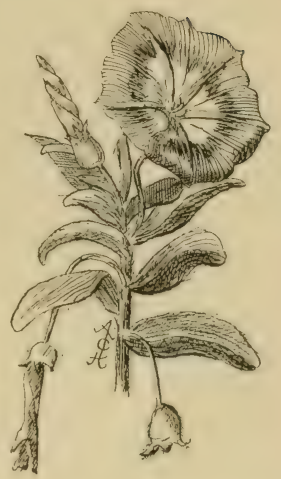

Fig. 35.-The dwarf Morning Glory in three colors differs widely from the tall form.

\section{Morning Glory, Dwarf-Convolvulus}

These plants deserve wider acquaintance. They are not strictly Morning Glories because the flowers are open all day in good weather. They also differ from the climbing sorts in that each flower is usually of three colors: The main part is either blue, pink, or purple; the center is yellow, and there is a band of white between the center and the expanded part. The specific part of the botanical name, Convolvulus tricolor (minor) refers to these three colors. The plants are usually only a foot tall. (Tall Morning Glories are discussed on page 109.)

UsE. The Dwarf Morning Glory is excellent for a low edging mass or for hanging baskets. It cannot be used in the same way as Sweet Alyssum, because the plants are not compact, but spread over an area of several feet. They are constantly in bloom and produce an excellent effect at the base of taller plants. In wet seasons they are somewhat apt to damp off.

Culture. Sow the seed in the border in May, or even earlier, and thin out the seedlings later so that they stand a foot apart. They are not readily transplanted. They delight in full sunshine. 


\section{Nemophila-Love Grove or Baby Blue Eyes}

These small, dainty plants from California, are of a spreading habit and the leaves are pale green, deeply cut and slightly hairy. In Nemophila insignis, the flowers are cup-shaped, blue or white, and often striped and mottled. The tips of the petals of $N$. maculata are spotted with deep purple, the rest being white. Most other Nemophilas found in the catalogs are varieties of these two species. The plants grow a foot tall and are profuse bloomers throughout the Summer.

UsE. These charming little annuals are excellent for edging beds, or for informal low groups in the border. Their long season of bloom commends them for wider cultivation. They are best grown in partial shade and in the moister soils. 'They are excellent pot plants for the greenhouse and clumps in the rockery are pleasing.

Culture. The seed may be sown in April in the open border where the plants are to grow. They should be thinned to stand at least, six inches apart. It is said that these flowers do best in soil which is not very rich, and in the cooler regions of the country.

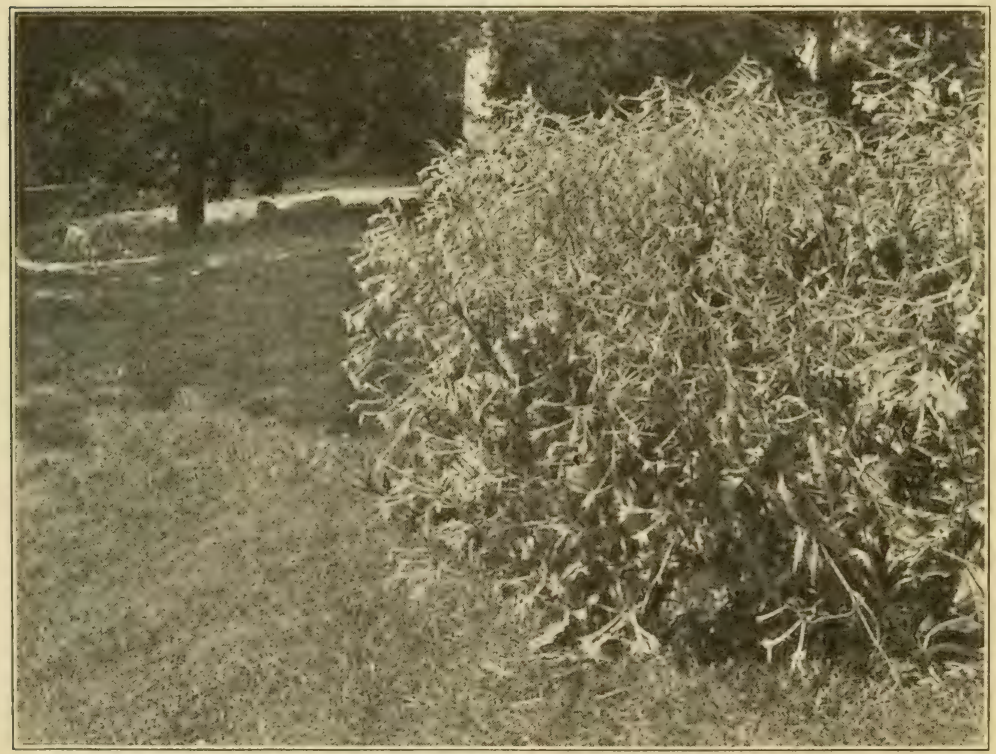

Fig. 36. - Ornamental Tobacco, this illustration showing Nicotiana affinis as it appears in the daytime with its flowers closed. 


\section{Nicotiana-Ornamental Tobacco}

The evening fragrance of the flowers of this plant is most delightful. Besides this, the flowers are attractive in form and color, which ranges from pure and creamy white, to deep pink, violet, crimson, and flesh. The shades are of the same soft tones as are found in the best Stocks. The flowers are borne in great profusion upon flower stems at least three feet tall. The leaves are usually abundant, and form a cluster about the base of the plants.

Nicotiana affinis and N. sylvestris are white species. N. Sanderæ is a pink hybrid, and from these forms the many sorts available have been derived. The flowers of $N$. sylvestris are quite drooping, have pointed lobes, and remain open all day, while those of $N$. affinis are less drooping, have oblique lobes, and open at night.

Uses. Few writers can resist advising amateur gardeners to plant masses of these flowers where the evening breezes will blow their fragrance toward a porch. They are slender in growth, and are seen to advantage when given a background of taller annuals.

Culture. The seed is very tiny and should be sown carefully. As the seedlings make a slow growth under cold conditions, it is wise to start them in the hotbed or sunny window. The soil should be finely pulverized and well enriched in order to produce tall plants and large flowers. The plants often self sow.

\section{Nigella-Love-in-a-Mist, Devil-in-the-Bush, Lady- in-the-Green, Fennel Flower, Maiden-in-the- Green, or Jack-in-the-Bush}

The fantastic names given to Nigella-which alone tempt anyone to grow it - have reference to the character of the flowers and leaves. The single, or double, blue or white flowers are furnished with a lace collar of green fern-like foliage. The common species is Nigella damascena, the favorite variety being Miss Jekyll. The plants grow one and one-half feet tall and usually bloom constantly from early Summer till Fall. The flowers are followed by attractive, inflated seed pods an inch in diameter. Relative to the name Devil-in-a-Bush, Mr. Breck writes that the name is appropriate because "that evil character is supposed to hide himself as much as possible from public view."

Uses. The airy grace lent by these flowers is delightful in the garden. For cut flowers they are also valuable, for they may be arranged easily in low vases. The more double flowers are preferable to the singles. Planted with California Poppies, Nigella 


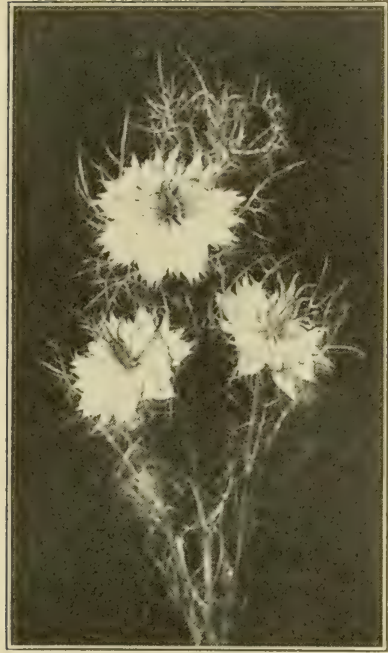

Fig. 37.-The blue Nigella flowers with their lacy collars are always interesting.

provides a pleasing contrast in colors.

Culture. Seeds may be sown in Autumn for these annuals are perfectly hardy and usually self sow. Springsown seeds bloom later and extend the flowering period. There is little need for sowing indoors, however, as the plants bloom when quite small. Thin the plants to stand 8 to 12 inches apart. In saving one's own seed keep only that from the double flowers.

\section{Enothera- Evening Primrose}

There are many perennial and biennial Enotheras, but several are popularly grown as annuals. Most of these sorts are either yellow or rosecolored. The sorts commonly cataloged are: CE. America, a Burbank hybrid, pure white, and four to five inches in diameter; $C$. rosea or mexicana, a rose-colored species; and $C$. Drummondii, a yellow. These flowers are fragrant in the evening, some of them closing during the day. The plants grow from one to two feet tall.

UsE. They are attractive border plants for sunny locations.

Culture. Sow the seeds early in the Spring in the open soil. Let the plants stand 8 to 12 inches apart.

\section{Pansy}

The Pansy, it would seem, is one of the most alluring of all garden flowers. Its little faces make most of us laugh when we look at them. The English have given the Pansy many nicknames, such as Call-me-toYou, Love-true, Three-faces-under-a-hood, Pink-eyed-John, Ticklemy-fancy, Bird's-eye, Jump-up-and-kiss-me, God-father, God-mother, Love-in-idleness, Kiss-me-in-the-buttery, Rob-run-the-street, and Heartsease. With such names, it is not strange that the French call it pensée, for this word means thoughts. Yet with all the Pansies' charms, there are some persons who do not grow them! 
UsE. Why speak of the use of Pansies? Everyone knows their garden value and their interest when arranged in a low howl for the table. Plant a few Browallias among the Pansies and note the charming effect. Pansies are also interesting when planted in a bed of such bulbs as Tulips, Snowdrops, Crocus and Narcissi. Just as the bulbs finish blooming the Pansies will be at their best. (See fig. 38, page 70.)

Culture. The best, largest, most attractively colored Pansies are the only ones we should grow, although seed of such sorts is a little more expensive than ordinary Pansy seed.

Late Summer sowing. When Pansy seed is sown in August, the plants will bloom in the early Spring. E. J. Steele, a Pansy breeder of wide reputation, suggests the following points about sowing seed:

1. Have your soil perfectly clean, free of weeds and trash, and pulverized to a depth of six or more inches.

2. On the level surface spread evenly a layer of pulverized manure, barnyard scrapings preferred, to a depth of at least one inch.

3. Overlay manure with one-half inch of the best soil you have, thoroughly pulverized.

t. Roll or rake down and tamp surface true and smooth.

5. Use the hose freely and soak down the bed several inches.

6. Sow your seed in drills or broadcast.

7. Cover as lightly as possible with your best soil or sand. Sand is the better.

8. Use a fine spray of water to moisten surface.

9. Allowing plenty of ventilation, keep your beds moist, quite moist, but not soaking wet, until plants come up.

10. Unbleached sheeting of the cheapest grade is good to retain moisture. As soon as the plants begin to come through freely, the sheeting should be removed permanently, and on the tops of the beds may be sifted a thin layer of barnyard scrapings. Never allow the beds to become dry. Any dryness after the seeds sprout is absolutely fatal. These directions are for sowing in the open garden, but will apply to flats or coldframes.

Spring sowing. If Pansy seed is sown in early Spring the plants will bloom in the Summer. The flowers will be small at first, but will become larger as the weather gets cooler.

A few facts about Pansy seed. Pansy seed is good for only nine months; old seed will not germinate properly.

When the temperature is above 70 deg., Pansy seed will not germinate. It prefers cool weather.

There are 25,000 to 28,000 seeds in an ounce, which will sow 100 feet of drill.

Generally the largest flowers of the rarest colors are found upon plants which have grown from seed that germinates slowly.

The better varieties are shy seed bearers and for this reason good Pansy seed is always expensive. 


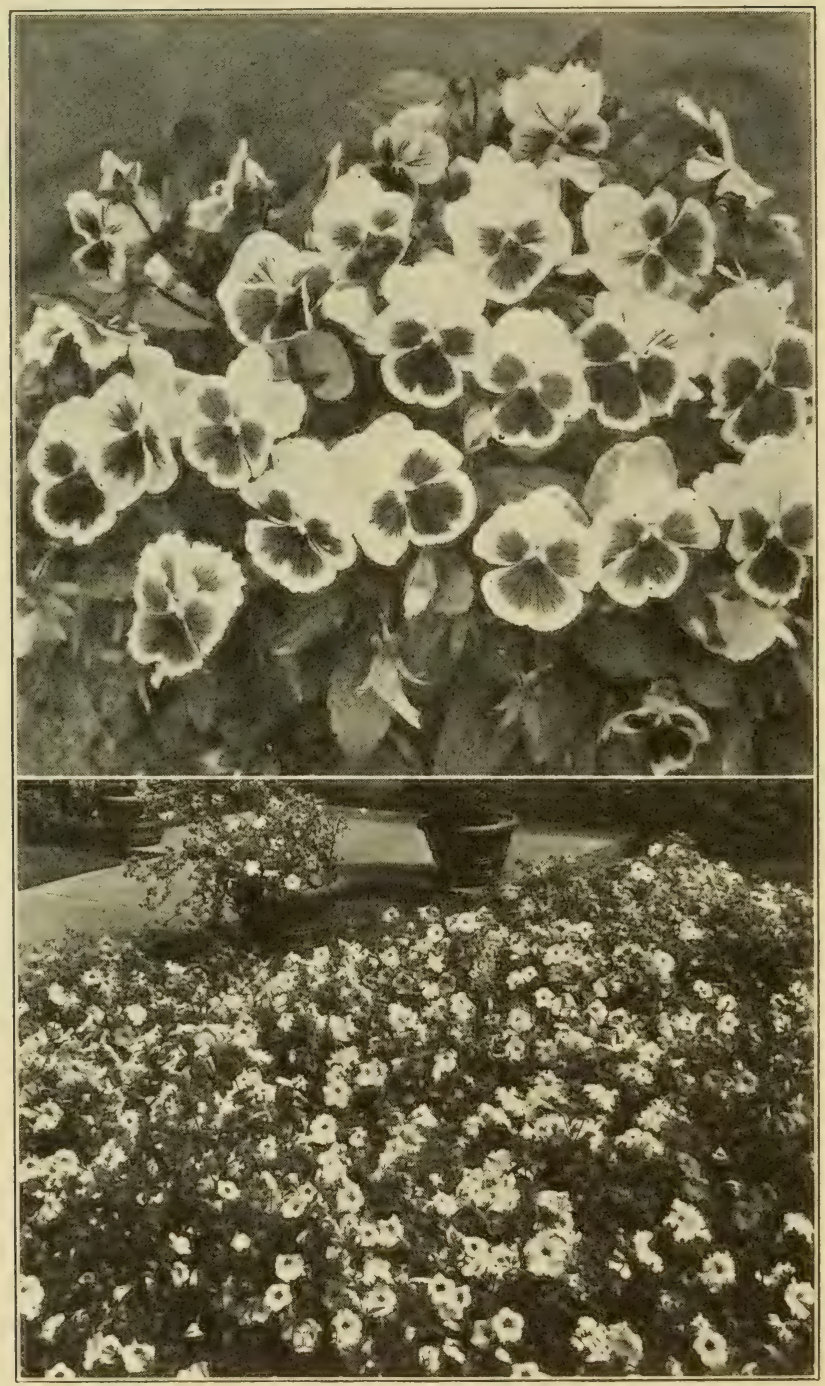

Fig. 38.-Above, a glorious mass of Pansies that surely make one want to grow flowers like them. Below, Petunias, whose glorious masses appear in greater profusion and last longer than those of most other annuals. 
Transplanling. The tiny Pansy plants should be transplanted when they have produced a few of their true leaves. Set them four inches apart in a coldframe if the seeds were sown in the Fall. Seeds sown in the open in Spring should be transplanted from the seed bed directly to the garden border. All too frequently transplanting results in smaller flowers.

Protection for Winter. After the ground is thoroughly frozen, the Pansies should receive some protection. Note that the advice is to protect them after the soil has frozen, the object being to keep it frozen and to prevent the plants from being heaved by alternate freezing and thawing. The best protection is afforded by using straw and a hotbed sash, but many persons do not grow enough Pansies to make them think that they can afford the hotbed sash. As a matter of fact, it is not necessary, but useful. If sash is not used, cover the plants with some fine tree branches, and upon them throw some coarse garden litter or leaves. The branches will prevent rain and snow from packing the leaves too tightly over the plants. Water standing upon Pansies through the Winter will be fatal to them.

Blooming Plants. Pansies are not hot weather plants, but if one removes all the flowers as fast as they fade so that seeding is prevented, they will bloom rather well in half-shaded places. They will not succeed at all, however, in dense shade.

When the plants show a tendency to produce runners, and the branches become long, they may be cut back, whereupon the plant will branch out and produce another crop of bloom.

\section{Pentstemon-Bearded Tongue}

Persons who are familiar with the Gloxinia-flowered Pentstemon, already know its beauty; to others who are not, we would say that the price of a packet of seed is entirely out of proportion to the pleasure of bringing these flowers into bloom. The plants grow two to three feet tall and bear brilliant flowers much like miniature Foxgloves. The colors range from white to deepest crimson, with the various tints of pink and lavender predominating. Usually the throats are white, and contrast nicely with the bright petals. These sorts are cataloged as large-flowered hybrids, or as Pentstemon gloxinioides. One of the best named strains is Sensation; the plants bear flowers almost two inches across. (See fig. 39, page 74.)

UsF. These handsome flowers are excellent for the border or for cutting.

Culture. Pentstemons are perennials, but the plants of the 
group described here are not always hardy, and are therefore treated as annuals. Sow the seed in a sunny window or hothed in March, and transplant to the open soil when danger of frost is passed. Let the plants stand fully a foot apart.

In favorable years, and in the milder sections of northern United States, they will live through the Winter, if protected by a straw mulch.

\section{Perilla}

Perilla is mentioned here because in years past it was a great favorite as a foliage plant. The leaves are dark purple and have a metallic luster causing the plant to resemble a Coleus. It grows about one and one-half feet tall. The pinkish flowers, in form like those of Catnip, are inconspicuous. There are forms with finely cut leaves and others with spotted foliage.

UsE. Perillas are used for masses of bright foliage in the border, where they offer a strong contrast when planted in the rear of lowgrowing white flowers, such as Sweet Alyssum, Candytuft, and white Stocks, or with the white-leaved Dusty Miller. They make rather attractive low hedges. It must he admitted that this plant is somewhat weedy, but it fits certain situations very nicely.

Culture. Perilla is usually listed as half-hardy, but in some sections of the United States it has run wild. Seeds sown in the open soil in April produce good plants that are effective all Summer. The seed germinates slowly. Let the plants stand one and a half feet apart. They thrive well in poor, dry soil and require but little attention.

\section{Petunia}

Everyone has some room for Petunias. Few other annuals produce so many of such large flowers. The colors have been improved to such an extent that there are now varieties to please us all. Recently nearly clear blues have been produced; the deep, rich purples and violets are superb; the light pinks are dainty; the whites are showy; the striped sorts are fantastic; the giant doubles are marvels of the breeder's art; the frilled sorts are popular-but why continue farther? The Petunias are altogether satisfactory. (See fig. 38, page 70.)

UsEs. Note that the catalogs list trailing as well as bush sorts. The former are incomparable for the hanging basket, garden and window. The more compact varieties are unexcelled for beds by themselves, or as wide edgings for other plantings. Steep banks which furnish a difficult mowing problem may be planted with Petunias. 
The writer will never forget their use in the "Garden of the Heart," in Central Park, New York City. The rock walle rise on several sides of the garden and into the chinks of these rocks: Dr. Southwick had sown Petunia seed; the resulting plants have continued to self sow there year after year. The flowers are small and the colors not especially good, but as a whole, the effect is worthy of admiration.

Culture. Seeds of Petunias may be sown in the sunny window or hotbed in March, or in the open soil in May. The plants should always stand nine inches apart. As the seeds are very fine, great care is necessary in sowing and in resisting the temptation to allow more plants to grow than will develop properly. Someone has said that the way to get the best single Petunias is to sow the best doubles, because the seeds of the latter do not produce all double flowers. The slowest and smallest seedlings are more apt to be doubles than those that germinate rapidly and grow quickly. The better sorts of Petunia seed will frequently cost more than the ordinary and inferior strains, but they are worth the difference.

Petunias prefer full sunlight, but will bloom in partial shade. They will thrive in rather dry soil if this is well enriched, and also upon soil either too rich or too poor for most annuals, if the moisture conditions are right. Thus one may see that the Petunia is most adaptable.

\section{Phacelia}

The best known sort is P. campanularia, which bears Gentianblue, bell-shaped flowers with contrasting white stamens. The plants grow nine inches tall and are somewhat hairy. They remain in bloom for a long time, the flowers being produced in one-sided curving clusters.

Uses. Phacelias are excellent edging plants for blue effects.

Culture. The seeds may be sown in the open ground in May. It will be well to pinch back a few of the plants while young; this will delay flower production, but result in well-formed plants. These plants prefer full sun and a light soil. Let them stand eight inches apart.

\section{Phlox-Texas Pride}

The brilliance and clean colors of the Annual Phlox, P. Drummondii, make it a favorite in the garden. The flowers range from white to pink, primrose, scarlet, crimson, rose, and lavender, some being per- 


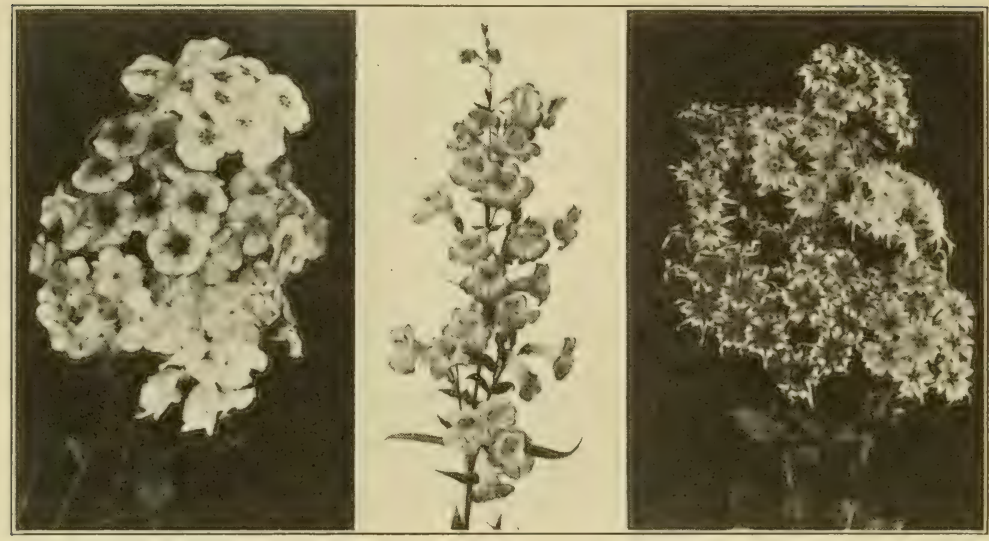

Fig. 39.- Left, Phlox, one of the most satisfactory of all annuals; center, the beautiful Gloxinia-flowered Pentstemon; right, Star Phlox, an interesting form because of its curious, pointed petals.

fectly clear while others have dark or white eyes. An interesting form known as the Star, Quedlinburg, or Fringed Phlox, is worth growing, not so much for its beauty, as for its curious, pointed petals. The plants grow from 6 to 18 inches tall, there being both tall and dwarf sorts. The flowers bloom throughout the Summer.

Uses. The annual Phlox is excellent for masses in the border, and for solid beds. The various colored varieties when planted in the borders may be so arranged as to form a veritable rainbow of color. As an undergrowth for the barer-stemmed annuals, a Phlox planting is useful, too. Those who grow Gladioli in beds often look for a ground cover that will bloom before the Gladioli. For this purpose few plants equal the annual Phlox. The clear, lovely colors are especially attractive cut and arranged in clear glass bowls.

Culture. As this Phlox is a half-hardy annual it is best to sow the seed in boxes in a sunny window or hotbed in March in order to hasten its blooming. It can, however, be sown outdoors after danger from frost is past. Let the plants stand eight inches apart. It will be wise to pinch back some of them to encourage branching. Phlox prefers the lighter soils, not greatly enriched, and full sunshine. Be sure to cut the fading flowers promptly so as to develop more bushy plants and lengthen the blooming period. 


\section{Physalis-Chinese Lantern Plant or Winter Cherry}

There are some annuals with showy fruits and among them none is so much admired as the Chinese Lantern Plant, which produces large, inflated, orange-red, lantern-like pods containing small, fleshy fruits much like Tomatoes. The flowers are inconspicuous, being borne in the axils of the leaves, and it is after the leaves have fallen that the fruit is most showy. The plants grow two feet high and form dense bushes. Two sorts are cataloged: Physalis Franchetii, which has large, deep red pods, and $P$. Alkekengi, which bears deep orange pods smaller than those of the former species. (See fig. 40.)

Uses. These plants are attractive in vases, for when cut, the fruits retain their color all Winter. In drying these fruits upon the stems, place the latter in a horizontal position, allowing the lanterns to droop sideways; otherwise some of the graceful appearance is lost. As garden subjects they are less valuable because the fruits are produced late in the Summer, and are more or less hidden.

Gulture. These plants often prove perennial, but one had best sow seed each year. Started in the open ground in early Spring they grow nicely. They prefer warmth and sunshine and enjoy frequent watering. They self sow and in some places are so prolific as to become almost wild.

\section{Pinks-Dianthus}

Admiration for Pinks is universal. In this book the forms of the China Pink only will be discussed. These annual forms can be distinguished from the perennial sorts in two ways: the flowers are without fragrance, and the leaves are broader. China Pinks are wonderfully bright in color-crimson, rose, purplish-red, salmon and lilac. The flowers are both single and double; the petals are toothed or sometimes attractively fringed, and three or four inches in diameter. The plants grow a foot tall. (See fig. 40, next page.)

UsE. Blooming as they do from early Summer until late Fall. Pinks are a constant delight both for garden display and for cutting.

Culture. The China Pinks are really more than annuals and if protected with a little straw in Winter, will bloom the second year. They should be started from seed each year, however, because they cannot be depended upon to live over. The old plants will bloom before the seedlings which should be transplanted to stand 8 to 10 inches apart. It is best to pinch them so as to produce branchy plants. A rich soil and sunshine are two of their desires. 


\section{Poppy-Papaver}

Why should we extol the Poppy? Why not? It was the favorite of the old gardens; it is the same choice flower in the newest gardens today. Dancing upon long, wiry stems, the single blooms remind us of hoop-petticoats of silk. The doubles also delight us, as we watch them open day by day pouring forth a great mass of petalage as they break from their tight buds. The colors are exactly the tints most of us admire, and if there be any one of these colors we do not like, we ('an choose others, for most of our Poppies are sold under variety names.

There are two distinct types of annual Poppies: the Shirley (Papaver Rhœas) and the Opium Poppy (P. somniferum). The stems of the former are slender and hairy; the flowers are single or semidouble and appear to be made of crinkled silk of the sheerest texture; the pepper-box seed capsules are small hut filled with seed. The stems of the Opium Poppy are smooth and thicker than those of the Shirley: the plants are taller; the flowers are larger, single, or completely double, and sometimes the petals are much fringed: and the seed capsules are large. Peony-flowered, Carnation-flowered and Tulip-flowered are some of the names applied to the various varieties of the Opium Poppy. The Ranunculus-flowered sorts are double varieties of the Shirley type.

Uses. Of course, Poppies are excellent in heds by themselves, or sown in the border, where some other flower has failed. Poppies are

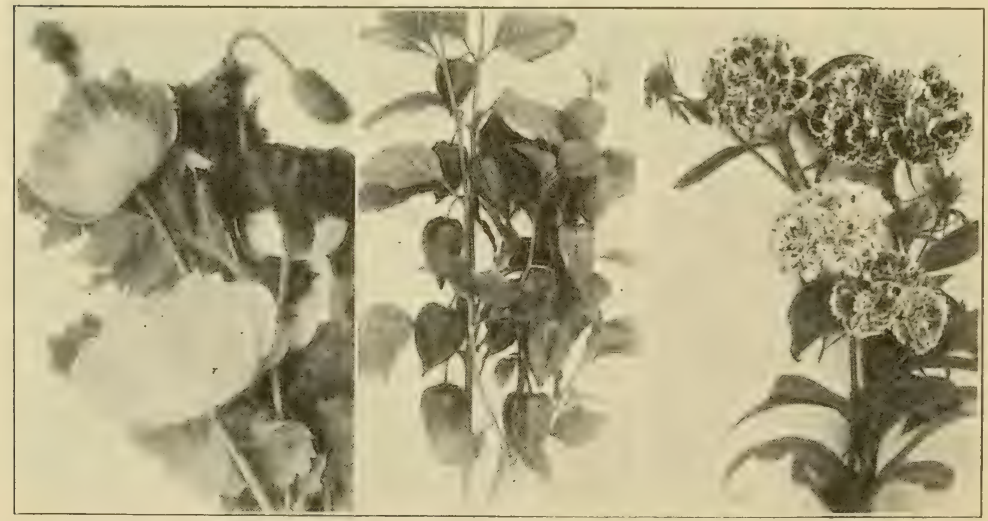

Fig. 40.-Lfft, the handsome, tall-growing Opium Poppy; center. Physalis seed pods are especially valuable for use in Winter vases; right, Double China Pinks, which frequently bloom for two successive years. 
like good friends in the garden: they are not mere callers, nor guests who disappoint us.

Some persons believe that Poppies are not good cut flowers. Even a poet has written,

"For pleasures are like Poppies spread;

You pluck the flower, its bloom is shed."

But the poet did not know that if he had plucked the Poppy in bud just before it had shed its green calyx, it would have lasted well in water. Poppies are exquisite cut flowers when cut properly.

Culture. Poppies are extremely hardy annuals so that the seed may be sown in the Fall, in the Winter upon the snow, in the early Spring, or in the Summer to extend the season of bloom. However, the seeds germinate best in cool soil.

As Poppy seed is very fine, it must be sown thinly. This is best accomplished by mixing sand with it. After sowing, it is best not to

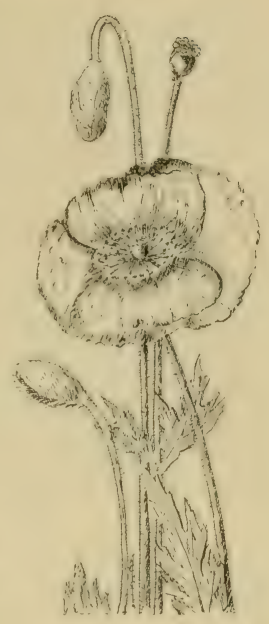

Fig. 41.-The graceful, silky petalled Shirley Poppies are old, old favorites. place soil over the seeds, but to cover the bed with a cloth or with grass clippings. The covering may be removed as soon as the seed has germinated, but until then it shades the seed and keeps it from drying out.

Thin the plants to stand six to eight inches apart. The seedlings do not transplant readily. Poppies will bloom for a short time only if the seed pods are allowed to develop.

\section{Portulaca-Rose Moss, Sun Plant or Seven Sisters}

When one visits an old lady's flower garden, no matter how small it may be, Portulacas are generally seen encroaching on the sidewalks and in other little out-of-the-way places where the dry conditions would support few other plants. The dazzling, glossy petalled flowers are clear yellow, white, scarlet, crimson, orange, and rose. The double sorts are most charming, and in many ways are superior to the singles. The plants are of a creeping habit, the leaves being mosslike and almost hidden by the flowers. The seeds, which resemble iron filings, are produced in a small, box-like capsule; when ripe the lid falls off and reveals them. (See fig. 42 , next page.) 


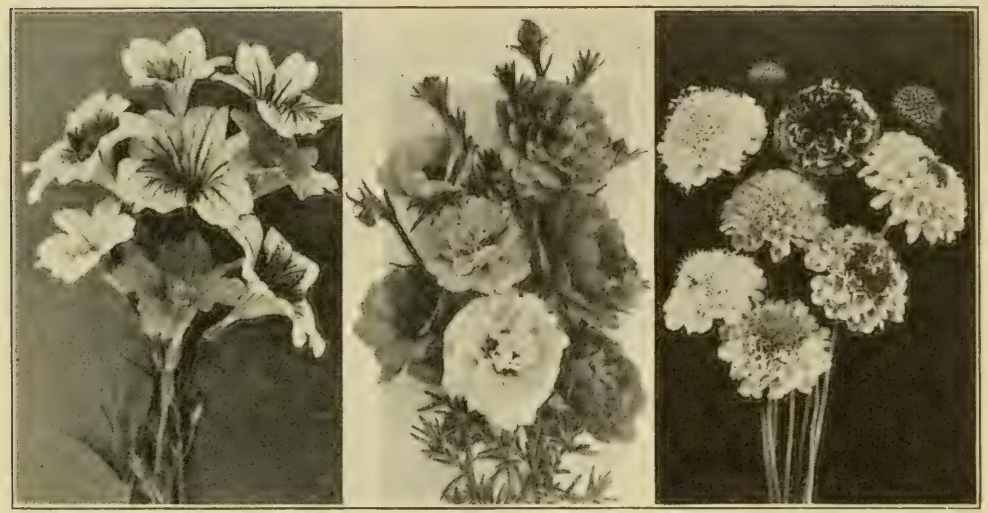

Fig. 42.-Left, the velvety, Petunia-like flowers of Salpiglossis are charming; center, the dazzling, glossy flowers of Portulaca are at home in even the sunniest and driest places; right, the lovely colors and strong, erect stems of Scabiosa commend it for vase arrangements.

UsEs. About each home there are spots so dry that nothing seems to grow in them. It is in such dry, sun-beaten situations that Portulaca thrives to the best advantage. It is, therefore, a good ground cover for beds, for edgings and for rock work. When planted in urns and other receptacles which are apt to be neglected in the Summer, these flowers seem to go right on blooming in spite of our inattention.

Culture. Seeds may be sown at the end of April and the seedlings thinned to stand four inches apart. The seed should be merely raked into the soil and not deeply covered. If given water and a little attention at the start the plants will thrive nicely.

Only a small proportion of the double sorts come true to seed in double form. These sorts also set seed but sparsely.

\section{Salpiglossis-Painted Tongue}

Were an artist to look upon a Petunia and wish that it had a delicate pattern traced upon its petals, he would create in his mind the Salpiglossis. The funnel-shaped flowers are borne upright upon slender but strong branches two feet tall. The flowers are crimson and gold, yellow and white, darkest maroon, scarlet and gold, violet and gold, and of many intermediate colors; they are velvety in texture, exquisitely penciled and curiously marbled. 
UsEs. Unlike the Petunia, this flower may be cut and will often last longer in water than on the plants. As a garden subject it is attractive, rivalling most other annuals in its regal colors, although the habit of the plant is not all that might be desired.

F. Schuyler Mathews, in "The Beautiful Flower Garden," writes: "Salpiglossis is not a prolific bloomer, but it is a dainty, retiring spirit, deserving a quiet corner and a few white-robed neighbors. It will not contribute much to color effect, but it will make up for this shortcoming by an xsthetic influence much to be desired in the garden where contrast and variety must constitute a great proportion of what we call beauty."

Culture. The seeds are extremely fine and require unusual care when started. It is wise to sow them indoors in March, although seed sown in the open soil will bloom nicely. When the warm days of Spring arrive and the soil is warm, the indoor-grown seedlings may be set out six inches apart. Little difficulty is experienced in getting the plants to grow after the seed has once germinated. Pinching out the centers of the young plants will cause them to branch. Sandy soils are best suited to Salpiglossis. It grows nicely in partial shade.

\section{Salvia-Sage}

It is unnecessary to describe the Scarlet Sage which is now too much planted in some sections of the United States. There is no question regarding its growth or its blooming qualities, but in some cities its hot color is seen on so many streets that it becomes monotonous. Someone has said that the color may be heard before it is seen. There is a most interesting Blue Sage which is unexcelled for the depth of its ultramarine blue shade. This is Salvia patens, and although it does not bloom as profusely as the Scarlet Sage (S. splendens) yet it is of an unusual color and worthy of culture.

Uses. Were we to cast our prejudices aside we would have to admit that the Scarlet Sage is one of the most popular of red-flowering annuals. When it is planted in long rows, the effect is dazzling. And to those who would plant the Blue Sage we would say that they must not be disappointed when the plants bloom, for they produce fewer flowers than the Scarlet Sage; however, the color is marvelously deep.

Gulture. Sow the seed of Scarlet Sage very soon after the first of March in a hotbed or sunny window. After transplanting the seedlings into separate pots or flats, keep them indoors until May when danger of frost is passed, after which set them in the border 
12 In 18 inches apart. The Blue Sage may be treated the same way, the plants being set at least a foot apart. The roots may be dug and stored out of reach of frost over Winter as these plants are perennials, and are good for more than one season if protected.

\section{Sanvitalia}

Sanvitalia flowers are much like tiny Zinnias, being golden yellow with very dark purple centers, some of them single and others double. The plants srow only six inches tall, or rather they are prostrate and spread over the soil instead of growing upward. They start blooming in June and continue until frost.

Use. They may be used as edgring plants or for low masses in a border. They are bright and showy in the rockery.

Culture. As the plants are hardy the seed may be sown in early Spring in the open and the seedlings thinned to stand eight inches apart.

\section{Scabiosa-Sweet Scabious, Pincushion Flower, Mourning Bride or Egyptian Rose}

The long stems and tufted flowers of the annual Scabiosa (S. atropurpurea) are charming. The colors also are pleasing in all caseswhite, light pink, rose, fiery scarlet, pale yellow, azure blue, and deep blackish-purple. The stamens are light in color and in contrast with the petals appear like pins stuck into the flower, hence the name Pincushion Flower. The seed heads are peculiarly bristly. The plants srow two to two and one-half feet tall. (See fig. 42, page 78.)

UsE. Its long stems, good keeping quality and charming colors combine to make this a most useful cut flower. In the garden also the Scabiosas are attractive and popular among bees and butterllies. The maroon or blackish-purple forms supply some of the deepest colors among all the annuals.

Culture. The seeds may be sown indoors, but it is just as well to sow them in the open in May. The seedlings should be transplanted to stand six to eight inches apart.

If the seed heads are picked off before they ripen, the production of flowers will be greatly encouraged and the plants will bloom untii frost. 


\section{Schizanthus-Butterfly Flower or Poor Man's Orchid}

The flowers of this plant are a delight to those who admire extreme grace, dainty markings and fantastic forms. Many flowers have been compared by writers to butterflies, but it is only this one that has received the name of Butterfly Flower. The Butterfly Weed (Asclepias) and the Butterfly Bush (Buddleia) are so-called not because they resemble butterflies, but because they attract them.

The flowers of the Schizanthus are white, pink, crimson, yellow, purple, lavender and rose, and are delicately spotted and blotched like the smaller butterflies. The blooms on a well-grown plant are produced in such profusion as to completely cover it. For the garden the dwarfer varieties should be chosen as the tall sorts grow rather slender and crooked. The leaves are attractive, being deeply cut and fern-like. (See fig. 43, next page.)

UsE. The Schizanthus is attractive displayed in small vases in which the flowers appear like small orchids. In the garden, unless the low-growing sorts are used, the plants will require staking, because the stems are weak and become crooked when not trained.

Culture. Sow the seeds out of doors in late Spring when the soil is warm. The plants do not transplant as readily as some annuals, and it is therefore wisest to move each seedling with a ball of earth. Let the plants stand a foot or cighteen inches apart and give them a little shade. The young plants are the better for the support of a stake early in their growth; it need not be strong nor over two feet tall.

The plants bloom in two months from seed. Pinching them early in their growth will make them more bushy and less straggling, a tendency to the latter form being their fault. Spraying with water daily in Summer will keep them healthy.

\section{Snapdragon-Antirrhinum}

Few of our flowers are as fantastic in form as the Snapdragon. At the same time the colors attract us. There are delicate pinks, such as we find in a Rose, the yellows are like giant flowers of Toad-flax, the deep maroons seem as though made of magnificent velvet. The catalogs list for our approval, many other colors. In height we find a great range, some growing as tall as three feet, others only eight inches. For most gardens those of medium height are best, since they produce long enough stems yet are not tall enough to demand stakes. 


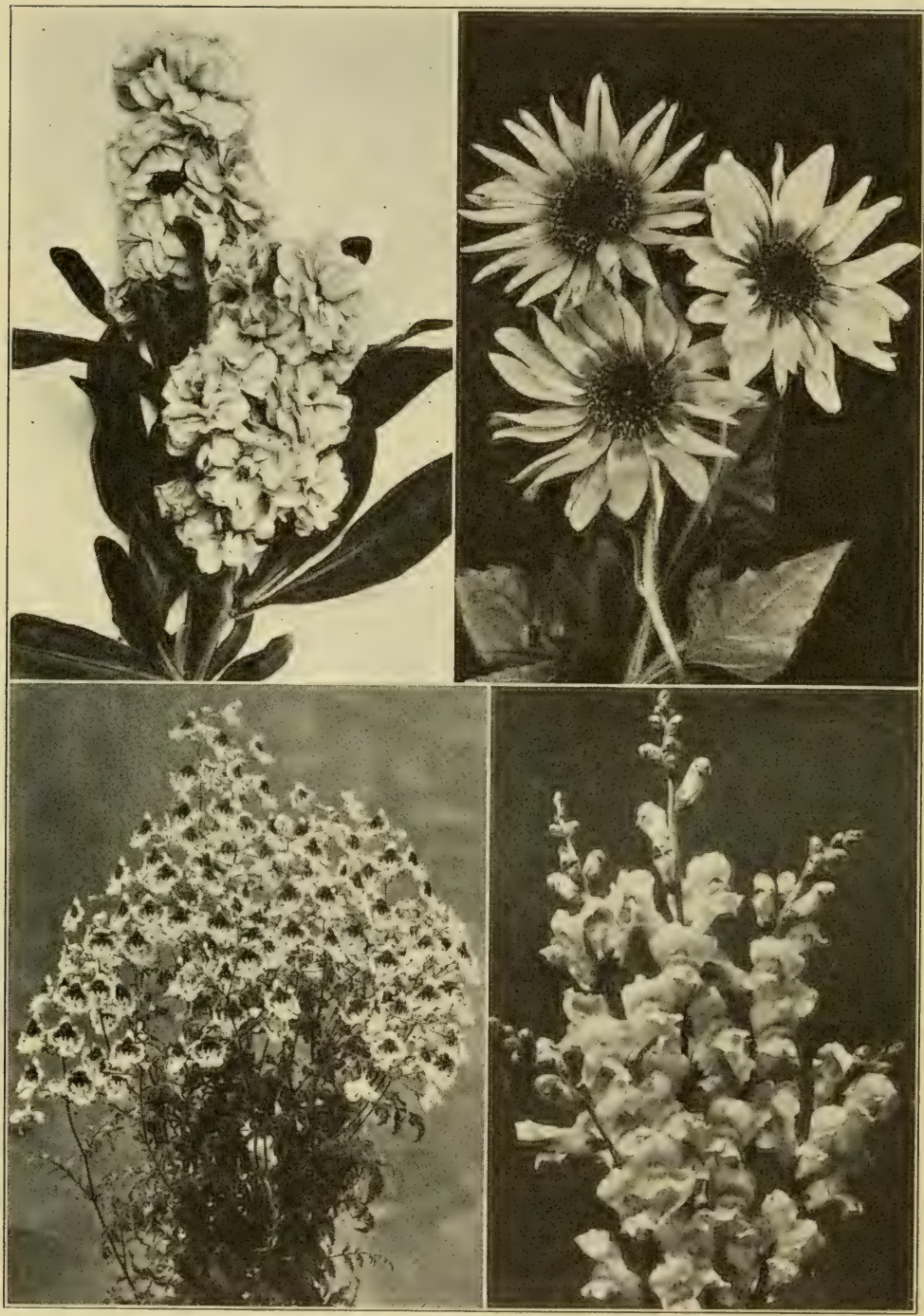

Fig. 43.-Upper left, the rocket spikes of Stock are almost universal favorites; upper right, Sunflowers help to fill the need for tall-growing, forceful annuals; lower left, the airy gracefulness of the Schizanthus is a delight in any garden; Iover right, Snapdragon, a good garden flower, a splendid cut flower, a flower for all persons and purposes. 
UsEs. Whole masses of Snapdragons are appealing, but individual plants have a charm which we cannot resist. As a cut flower the Snapdragon is very adaptable.

Gulture. Seed may be sown indoors when an early start is desired, but the Snapdragon blooms nicely when planted directly in the open soil. Transplant the seedlings to stand a foot apart. The plants are as well adapted to shady places as any other annuals.

\section{Stock or Gilliflower-Matthiola}

The delightful, and at the same time, unusual, fragrance of the Stock is one of its chief charms. But the plant is not only admired for this character; it is also a most estimable garden flower. The sorts most commonly grown are derived from Matthiola incana, the TenWeeks Stock, which species has given rise to two distinct types of plants-those which are very branching, perpetual blooming and known as "Cut-and-Come-Again" Stocks, and those which naturally produce one large truss of bloom and then branch. Of these types some grow two feet tall, while others are more dwarf.

Stocks may be purchased in many colors-white, rose, crimson, purple, light blue, dark blue, and sulphur-yellow, and the colors are soft, rather than brilliant. Double stocks are handsome and grow from the seed of certain plants which in turn produce double flowers.

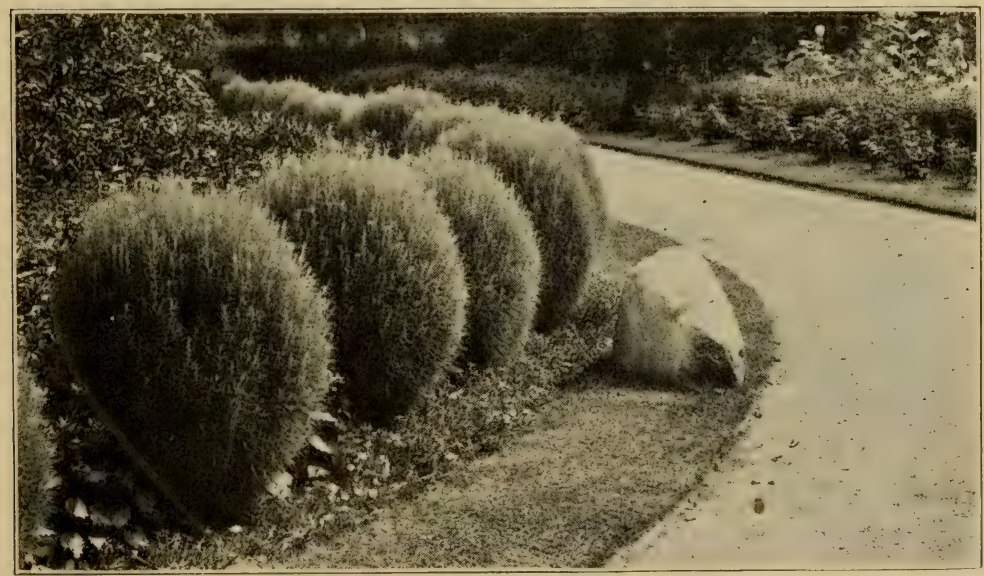

Fig. 44. - An excellent example of the successful use of Kochia, or Summer Cypress. Uniformity of size and shape is a valuable characteristic of the plants. (See next page.) 
A large percentage of such seeds will produce doubles if good strains are purchased. There are early as well as late Stocks, the latter being the better for cut flowers and the former being especially good for the garden.

Culture. Stocks enjoy a well-enriched soil, thriving best in cool, moist weather. It is wise to start some plants early by sowing the seeds in a sunny window in March and transplanting the seedlings when large enough, to small pots. Freguent transplanting will result in compact plants. The seeds for later flowers may be sown out of doors in May.

In planting Stocks in the garden, allow at least a foot between the plants. If they are pinched, they will send up a number of excellent trusses of bloom. For this reason, it is suggested that some of the plants be pinched and others be left to develop their flowers normally. When the flowers are cut, this has the same effect as pinching and the plants tend to branch anew.

\section{Summer Cypress-Kochia}

This annual in habit is somewhat like an evergreen and has been variously called Summer Cypress, Belvidere, Mexican Fire Bush and Burning Bush. The plants grow quickly and make an upright, compact growth, producing numerous branches covered with fine leaves. There is an objectionable feature that must be mentioned. The plants, in the Autumn, turn a bluish-red, that combines with the colors of few other plants. The plants grow two to two and one-half feet high. $K$. tricophylla rather than K. scoparius is the species most commonly listed in catalogs; plants of the former are oval, while those of the latter are pyramidal. (See fig. 44, page 83.)

UsE. Early in the season these plants make a rapid growing hedge. Often one desires such an effect if it can be produced quickly.

Culture. It is well to soak the seeds in warm water for a day before sowing. They may then be started indoors if the plants are wanted early, although outside sowing is usually practiced. Set the plants two feet apart thus allowing their symmetrical form to develop. In the government bulletin on "Growing Annual Flowering Plants," the statement is made that these plants grow best where an electric are lamp supplies light at night. The plants often self sow. In semishady places they do not develop so as to make regular specimens.

\section{Sunflower-Helianthus}

The Sunflower is bold, he is tall, has a lot of bluster and bravado about him, but he is not coarse; no, he does not intrude upon us. We 
like to have him look over our fences; we like to watch him looking down toward his feet to see how tall he has grown. If any flower deserves the name of a "Sunburst" it surely is the Sunflower. (See fig. 43, page 82.)

Kinds. There are two sorts of annual Sunflowers. The seven- or eight-foot fellow is Helianthus annuus, of which there are many interesting forms; some are attractively doubled like Chrysanthemums, or Asters, some are dwarf, some are ball-like, and look like golden Dahlias, while still others have been developed that are rich chestnut red either throughout or only in the center, wherein their hues resemble the colors found in the Blanket Flower.

The second interesting species is known by many names, such as Miniature, Cut-and-Come-Again, Dwarf Branching, and Cucumberleaved, but really is $H$. debilis ( $H$. cucumerifolius). It grows three or four feet tall and is bushy. The flowers, unlike those of the first species, are usually only three inches in diameter, and the yellow petals are often twisted.

UsEs. The uses for the tall, large sorts readily suggest themselves; there is always space for a few of them in a garden. They make attractive hedges in the distance. They screen poultry yards and as the seeds drop, they are greedily eaten by the chickens. The Cut-andCome-Again sorts are suitable for cutting and are showy in the border.

Culture. The seed should be sown in the open ground when the trees are coming into leaf. A rich soil suits both sorts best. The tall forms should stand two feet apart, and the shorter ones a little closer. The Cut-and-Come-Again sorts commence to bloom in June and continue all Summer.

\section{Swan River Daisy-Brachycome}

The Swan River Daisy is a tiny blue, pink, or white blossomed plant, the flowers being hardly more than a half inch in diameter. The plants grow about ten inches tall, and are of a compact habit. They are useful for edgings, producing as they do a profusion of bloom throughout the Summer. The flowers may be cut for use in small vases where they combine daintily with Sweet Alyssum.

Culture. It is wise to sow the seeds in the hotbed or a sunny window in April in order that the plants may bloom early. For use as edging plants, transplant the seedlings so that they will stand five or six inches apart. Cut off the old blooms as they pass. These plants succeed best in the cooler regions of the United States. 


\section{Sweet Peas-Lathyrus odoratus}

The Sweet Peas of our gardens delight us while they provoke us. We sincerely wish that they might bloom for a longer time, yet they are an unqualified joy when they are in flower.

Many thoughts arise in the minds of true Sweet Pea lovers. For instance, Helen Milman, in "My Kalendar af Country Delights," writes: "I think the Sweet Pea is a frivolous flower and leads a butterfly's life, it wanders anywhere, and clings to anything, and has not any definite aim or ideal." And Keats when he thinks of Sweet Peas, writes:

"Here are Sweet Peas on tiptoe for a flight, With wings of gentle flush or delicate white, And taper fingers catching at all things

To bind them all about with tiny wings."

Another poet has written this jingle:

"Peas along the border, Peas upon the lawn,

Peas against an eastern wall to welcome in the dawn.

Peas among the Roses, Peas behind the Pinks;

Peas to catch the western glow when evening sunlight sinks.

Peas upheld with Chestnut, Peas held up with Ash;

Peas asprawl on Hazel spray, Peas on Larchen brash.

Peas on stiff unyielding wire, Peas tied up with string;

Peas upon the trelliswork where Rambler Roses swing.

Oh! Merry, merry, merry, are the gay Sweet Peas;

Plant them when and how you will, it's certain they will please."

Frankly, however, Sweet Peas cannot be planted "when and how you will," and it is to pointing the way to success in the "when and how" that the remainder of this chat on Sweet Peas will be devoted.

Types of Flowers. There has been a gradual development of the Sweet Pea from the wild form in which the flowers were purple and small, to the modern race of ruffled sorts. The most popular today are those listed as Spencers, Waved and Orchid-flowering varieties. In these the flowers are large and frilled, three or four are borne on each stem and there is a wide range of exquisite colors. The older type, known as Grandiflora, includes the varieties that were seen before the year 1900. The early flowering varieties now listed are the types almost entirely grown in greenhouses today. These varieties bloom two wecks earlier and have the habit of flowering while rather small, after which they branch. (See fig. 46, page 90.)

Autumn Preparation of the Soll. Sweet Peas delight in having their roots in cool, deep soil, and for this reason it is wise to prepare the soil in the Autumn, because in the early Spring it is hardly 


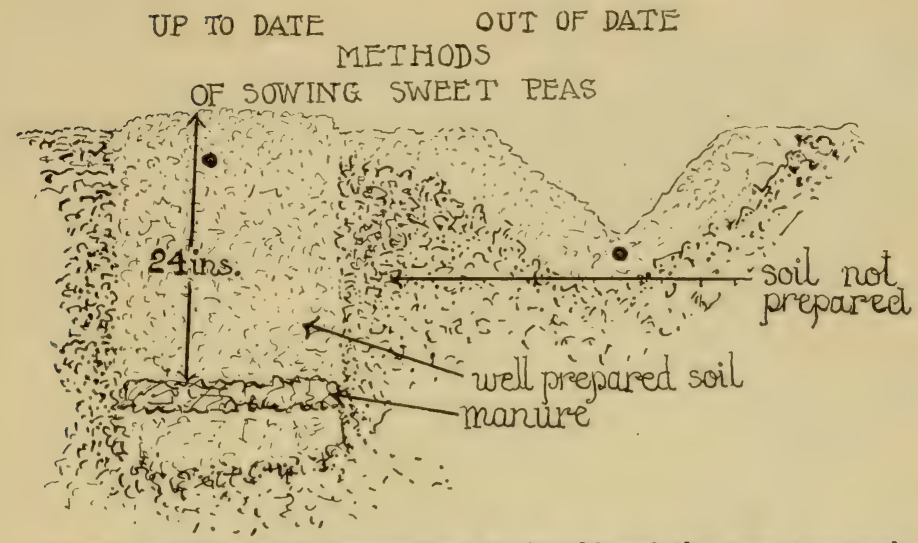

Fig. 45. - A diagramatic comparison of the old and the new, approved methods of sowing Sweet Pea seed. Well-enriched, deeply prepared soil is essential.

dry enough to work. Dig a trench at least two feet deep and a foot or more wide. Place several inches of manure in the bottom, and fill in with good soil so that the filled trench is rather arched at the top. The soil will settle somewhat and anyway, we do not want these rows to be below the soil level in early Spring. Furthermore, the rows when mounded, will dry out more quickly, and permit earlier planting.

Fall Planting. When Sweet Peas are planted in the Fall, the flowers are produced earlier. This method is successful south of New York City on most soils, but farther north it is worth while only on well drained, sandy land. In localities where there are few alternate freezes and thaws, and the snow covers the soil most of the Winter, this method is highly recommended.

Dr. A. G. Beal, in charge of the Sweet Pea trials at Cornell University, has experimented much with Autumn sown plants and writes, that after preparing the trench, as just described,

"The soil must be treaded in the trench so that it will not settle with the action of the Winter frosts. In fact, it is better to ridge the soil slightly over the trench to allow for possible settling, and for draining off surface water. In this ridge, there should be made a small furrow, two inches deep. The seeds should be sown one inch apart in this furrow, and covered with two inches of soil. The row should be left slightly elevated when the planting is finished. The important point to keep in mind about Fall-planting Sweet Peas in the northern states, is to plant so late that the plants do not make any growth above ground until Spring. If the plants appear above ground they are killed by the Winter. Seeds that have only sprouted are not harmed. In central New York it is our experience that 
about November tenth is about the right time to sow, but, of course, this varies with the season.

"After the ground freezes, a mulch of manure should be placed over the row, and if the snow remains all Winter, the conditions are very favorable. On the approach of bright, warm, sunny weather, examine the Sweet Peas, and, if they are found growing, remove the manure. It is a good plan to leave the strawy portion between the rows, or near at hand for a while, so that it may be placed over the plants during sudden cold spells.

"The Fall-sown Sweet Peas begin to grow earlier than it is usually possible to plant in Spring. They develop during the cool weather, make a better root system, and are stronger than plants from Spring-sown seed. The seeds of the standard varieties are so cheap that the Fall planting of Sweet Peas is well worth trying. Should the seed perish, the rows may be replanted in the Spring."

Good Friday Sowing. There is an old rule which says that Sweet Peas should be sown on Good Friday. This means simply that Sweet Peas may be sown as soon as the soil thaws in the early Spring, because the plants grow best during the cool, moist months.

It was formerly believed that Sweet Peas should be sown in shallow trenches six or eight inches deep, but it is now generally agreed that the row should be raked level and the seed sown only a half inch deep. It is best to sow thinly, meaning that only enough seed should be used so that the plants will stand six inches apart. Sweet Peas may also be sown in double rows a foot apart; this will allow space for the plants to develop and will at the same time produce a large guantity of bloom.

Early Blooms from Pot Sowings. Sweet Peas may be brought into bloom several weeks earlier and the plants will be better developed if started indoors, or in a hotbed. Edwin Jenkins writes, in the American Sweet Pea Society Bulletin:

"Do not despair of raising good Sweet Peas if you are without a greenhouse, or even a coldframe; much may be accomplished by a little forethought and a little ingenuity. A flat, 24 inches long by 12 inches broad takes up but two square feet of room, and may be set in a house window. It is easily moved from place to place, holds about 100 plants in paper pots (which are four inches deep) and will give the plants plenty of room until they can be planted out. Now, these plants are enough to plant a single row 100 feet in length, or a double row 50 feet long, which is as much as many people can handle. Further, they will bloom longer and give superior flowers to any that may be planted closer; in fact, good sturdy plants set out in fairly rich soil will fill the space if planted two feet apart.

"This outdoor planting must be done as early as possible, and the plants protected at night from frost. A good way to protect the plants in the row is to nail two boards together, so as to form an inverted $V$, and set it over the plants at night until danger from hard frost is past."

To Insure Germination. Many Sweet Pea seeds are very hard and germinate slowly, if at all. It has been found wise to give them some sort of treatment to insure prompt sprouting. Some soak 
the seeds in acid for a half hour, but the simplest method is to cut off a small piece of the seed coat on the side opposite the growing point. When such seeds are sown a half-inch deep in sand, they will germinate readily because they can soak up water easily. When so treated they germinate in a week and may then be placed in small pots to grow.

Light colored seeds which usually produce the white and paler tints and the mottled seeds (usually of the lavender, blue and mauve sorts), are apt to decay when the soil conditions are not favorable, It is the red, crimson and scarlet sorts that bear the hard seeds which it is well to germinate before sowing.

Supporting. As soon as the seed is sown the gardener should consider the matter of supporting the plants. When the seedlings show a tendency to produce tendrils, they want to get hold of something and should not be allowed to sprawl over the soil. No matter what method of supporting is used, small, branchy twigs should be placed near the plants, and if the stems are slow in taking to the twigs tie some of them up.

Tall brush is the ideal material for supporting the plants because of its width, and the many twigs to which the plants can fasten themselves.

Wire netting may be used; it is neat and lasts for years. Some object to it because it is difficult to clean the tendrils from it in the Fall when rolling it up for the Winter.

Stakes, eight feet long, may be driven into the row and strong strings stretched between them. This is an inexpensive method, but as the strings stretch the effect often becomes unsightly. The lower strings should be placed five inches, and the higher ones farther apart.

A common English method and one worthy of trial in this country is to sow the seeds in circles several feet in diameter. Wire netting or a tepee effect made of stakes provides a support. The clump effect thus produced must be interesting.

Fertilizers. If the soil is rich, little fertilizing is advisable, except a light dose of nitrate of soda, or dried blood when the stems begin to get short. In the case of nitrate of soda, we strongly advise dissolving it in water at the rate of a tablespoonful to a gallon.

When the soil is none too good at the start it will be advisable to give a dressing of bonemeal shortly after the plants are severa! inches tall. Scatter the bonemeal on both sides of the row so that the soil is white and rake it in. Some specialists believe that soot dusted over the soil every ten days brightens the color of the flowers. 


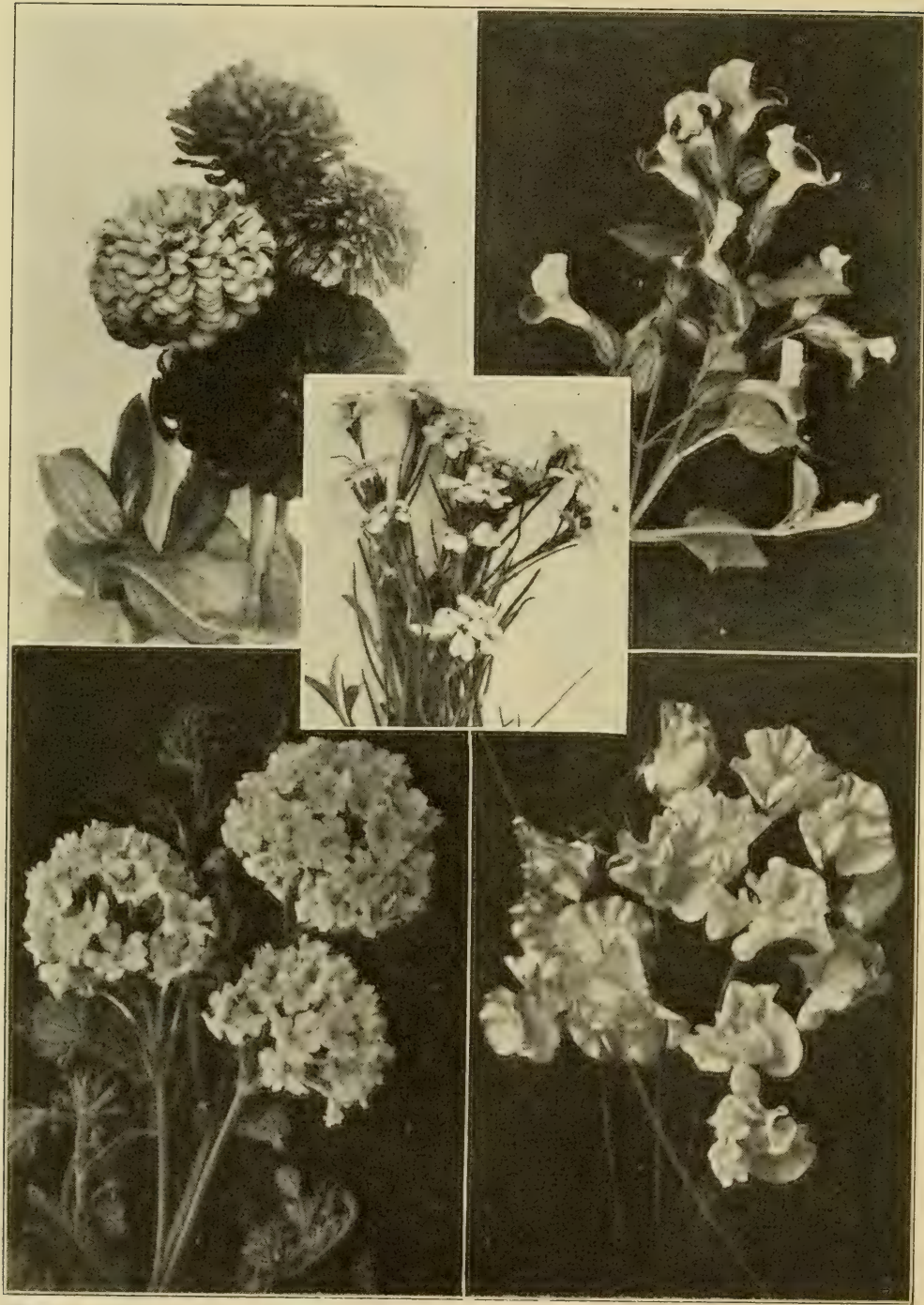

Fig. 46. - Upper left, the Zinnia is a hearty flower that laughs at adverse conditions; upper right, Torenia flowers provide a striking contrast between violet and yellow; lower left, Verbenas are old favorites, but they win new admiration each year; lower right, a typically beautiful variety of the Orchid-flowering type of Sweet Pea; renter, Virginian Stock may be familiar to many who do not know its name. 
Mulchivg. Those who wish to keep their vines blooming as long as possible may try mulching the rows with decayed leaves or straw. This keeps the soil from drying and baking. Three inches of material should be used, but no more.

When a mulch is not used, the plants must be cultivated so that at no time shall the soil be baked at the surface.

Watering. Sweet Peas enjoy water and will thrive when given large amounts. A shallow irench hoed out six inches from the rows will be a convenient aid in watering.

Prскing the Blooms. Sweet Peas must be picked often and continuously if one wishes to fully enjoy them. Neglect in this particular soon causes them to go out of bloom. The best gardeners cut the flowers rather than pull them. Buy your Sweet Pea seed and do not try to save it, for it is better to have the flowers. It is well to cut some foliage with the flowers because this acts like a light pruning, causing the plants to branch. Foliage and young shoots are also useful when arranging the flowers.

Dr. A. C. Beal writes in Reading Course Lesson 151 of the New York State College of Agriculture:

"In order to have fine flowers and a long succession of bloom, it is infinitely more necessary to keep the seed pods rigorously picked off' than it is to cultivate, mulch, or water the plants. The latter operations go for naught unless the pods are picked off. The writer thoroughly believes that the importance of watering has been overemphasized and that too many amateurs prefer to use the hose rather than to pick pods; then they assert that the Sweet Pea is not what it used to be, that it has lost constitution. Of course, the more highly developed the variety, the less certain it is to bear up under neglect."

(Although from some of the older varieties in the College trials, no seed pods were picked, they continued blooming profusely, while the plants of the modern, waved sorts became in most cases, completely destitute of flowers under this treatment.)

"The same holds true with regard to length of stem. Some plants of Countess Spencer were treated as above in order to note the effect, and for them the season was over early in August. The lesson is that if the grower does not intend to comply with the requirements of the improved types, it is better to grow the small-flowered, precocious varieties."

Insects and Diseases. Plant lice are frequently troublesome on Sweet Peas. When this is the case spray the plants with a nicotine solution. Red spider is prevalent late in the season, and may be controlled by merely spraying with water daily. Its presence may be detceted by a whitish appearance of the foliage and a webby covering. 
This should not be confused with mildew, which appears as a white powdery growth on the foliage. As the mildew affects Sweet Peas only after their season of bloom is over, it is not usually serious. Mildew is controlled by dusting powdered sulphur upon the foliage. Other diseases affect sweet Peas, but the methods for controlling them are not understood. Diseased plants should be pulled up and burned to prevent spreading the spores of the trouble.

\section{Torenia-Wishbone Flower}

Those who have not tried this annual, nor seen it growing, have a pleasant surprise in store for them if they will raise a few plants. It is a gem. The flowers of Torenia Fournieri are violet and lavender with a prominent yellow blotch on the lip. There is a less attractive white variety. In the center, the stamens are arranged in the shape of a wishbone, hence the common name. The pistil in the center is sensitive, and when it is touched, the two lobes gradually close and hold any pollen which may have fallen upon them. The plants grow a foot tall and bloom till late frost. (See fig. 46 , page 90.)

Use. For close inspection, by virtue of its innate charm, the Torenia is a flower of beauty and interest, although its garden effect is not as showy as that of many other annuals.

Culture. The seed is fine and when carefully sown in late March in a sunny window, will give excellent plants that will bloom all Summer. They are tender annuals so the seedlings should not be placed in the open border until the weather is warm.

We were interested to read in Bailey's "Standard Cyclopedia of Horticulture" that in Florida Torenia is an excellent substitute for the Pansy, which is cultivated with difficulty that far south. Young plants spring up in the rainy season, coming from self-sown seed. It is found abundantly in the sort of moist situations which, in the North, suit Forget-me-nots.

\section{Verbena}

The rich colors of the Verbena have endeared it to us for years and years. Our mothers and their mothers grew it, and we have seen them use hairpins to get it to root along the stems. Most persons know its range of brilliant colors: the pinks are like those found in Trailing Arbutus; the purple is truly royal; the scarlet is like rich velvet; the white is as pure as snow; the blue and lavender tints are dainty; and besides the clear color varieties, there are sorts with white and dark 
eyes, and others that are striped. All the above are forms of Verbena hybrida. There is another annual species of great charm knows as the Moss Verbena ( $V$. erinoides). Its flowers are purplish-blue or white, and the leaves are fern-like. (See fig. 46, page 90.)

The Lemon Verbena, so-called, is not really a Verbena nor an annual, but in California at least, is a woody, trailing plant. The leaves are deliciously lemon-scented. Small plants may be raised during the Summer and brought indoors for Winter, as they will not tolerate the cold.

UsE. The Verbenas are suitable flowers for ground covering, and make good masses in the border. As cut flowers they are attractive when loosely arranged in low howls and vases.

The Moss Verbena is especially recommended for hanging baskets and urns, although useful in the garden as well.

Gulture. Sow the seed in a hotbed or sunny window in March and the plants will begin to bloom in June. Sown outdoors when the trees are in leaf, the plants flower in July or August, keeping up a continuous display. Set the plants 12 to 18 inches apart and they will make a dense mat of bloom. It is well to pinch them back early in their growth. Keep the flowers cut so that the plants may not go to seed.

\section{Virginian Stock-Malcomia}

This old favorite of our grandmothers' gardens is often seen in places where it has self-sown for years. The common species, Malcomia maritima, bears four-petalled, lilac, red, and white flowers somewhat resembling those of ordinary stock. The plants grow six to eight inches tall. (See fig. 46, page 90.)

Uses. It is excellent for the rock garden and for masses in a border, and may be used as an edging plant.

Culture. The seed may be sown in the Fall in which case the plants will bloom early in the Spring. But Spring sowing will prolong the season of bloom. The common mistake in growing Virginian Stock is to neglect to thin the plants so that they will stand eight inches apart.

\section{Zinnia_-Youth and Old Age}

At last the Zinnia has come into its own. Because it is of easy culture and does well for anyone, it has in the past been admired less than it deserves. Recently the seed growers of California have de- 
veloped enormous flowers of unusual shapes and with excellent colors. Note that the catalogs are listing curled and crested sorts and wonderful new giant flowered varieties, measuring seven and eight inches across. In the opposite direction there are charming dwarf sorts which produce small flowers that cover the plants. The taller sorts are three feet in height while the dwarf varieties are only a foot tall.

The colors of Zinnias are soft but glowing and include rose, orange, crimson, scarlet, yellow, salmon and purple. The above mentioned forms are cataloged as varieties of Zinnia elegans; there is, however, another species, $Z$. Haageana, which is dwarf. Its flowers are commonly shades of orange, but many new colors are advertised. There is also a type with star-like, narrow petalled flowers known as Stellata hybrids. This attractive dwarf form is offered in all colors. (See fig. 46, page 90. )

Use. The modern Zinnias, though stiff, may be effectively arranged for home decoration and show up most effectively under artificial light. There are many pure colors and as these usually combine well, the effects possible are charming. For low bowls the dwarf sorts are superior to the larger-flowered tall varieties. They need no added green to set them off, for the Zinnia is well furnished with foliage.

In the garden, Zinnia effects are rich, the plants are thrifty and the colors are decided. In bold masses for distant effects few other annuals can rival them. The dwarfs are especially valuable as edging plants, their profusion of bloom and foliage serving to cover the soil completely. The rank foliage provides a background for lower growing annuals.

Culture. Give these excellent new strains a little extra care and note their appreciation. Sow the seed in a sunny window in March. Transplant the seedlings to shallow boxes. Set the plants out in the open soil, when the weather is warm, placing the plants in well-enriched soil. One might even be kind enough to place some manure deep down beneath where they are to be planted.

It is only seed of the largest flowering sorts that should be expected to give the giant flower: There is a difference of opinion relative to the distance apart to set the plants. Some persons set them 18 inches apart, and thereby get the largest flowers; others claim that by planting closely, the plants produce fewer, but larger flowers. It is easy enough to follow both sorts of advice and see for yourself. The dwarf sorts are surely better when each plant is given a space of two feet on each side. 


\section{ORNAMENTAL GRASSES}

THE appreciation of grasses as garden subjects has progressed 1 but little since the following appeared in Hooper's "Garden Guide," in 1883 :

"The increase of refinement in horticultural taste has in recent years brought into prominence several classes of plants which were formerly neglected as matters of ornament. They lack the brilliancy of color, and were, therefore, not deemed worthy to be elevated from the position of "wayside weeds" to that of denizens of well-kept gardens. Beauty of form, however, has fortunately come to be considered a feature of no mean value; and consequently plants which can not arrest the eye by their splendor, have been sought after for the gratification they give to elevated taste by their grace and elegance. Among these are the grasses."

If grasses were more rare we would think them the daintiest of flowering plants. Plumy, waving grasses, silvery, slender grasses, tall, majestic grasses, dainty, trufted grasses - all of these have a real place in our gardens. (See fig. 47 , next page.)

UsE. The grasses lend a mistiness to the flower border that is charming. The low sorts are excellent for bordering tall plants which should have their feet covered. A bed of Cannas may well be planted with a fringe of Fountain Grass around its margin. The beauty of some of the gaudier colored flowers is enhanced if they are surrounded with some of these grasses. Other grasses are useful to cut for the Winter bouquet, and they are attractive planted in beds by themselves.

Culture. In general, grasses are easy to grow; the hlunder usually made is that they are not given sufficient room to develop. They are small at transplanting time, and it seems a waste of garden space to plant them a foot or more apart, but this is just what should be done. Each grass plant should be set out by itself except in the case of the tinier sorts which may be transferred in tufts. The particular differences in culture are noted below under each of the grasses.

\section{Agrostis nebulosa-Cloud Grass}

This is a fine, hair-like grass, giving a hazy effect when planted in the border. (See fig. 47, A, page 96.) It blooms in the Summer and grows 18 inches tall.

\section{Briza-Quaking Grass}

There are two annual species of this genus: Briza maxima, which grows 18 inches tall, and B. minor (gracilis), which is but a foot tall. 


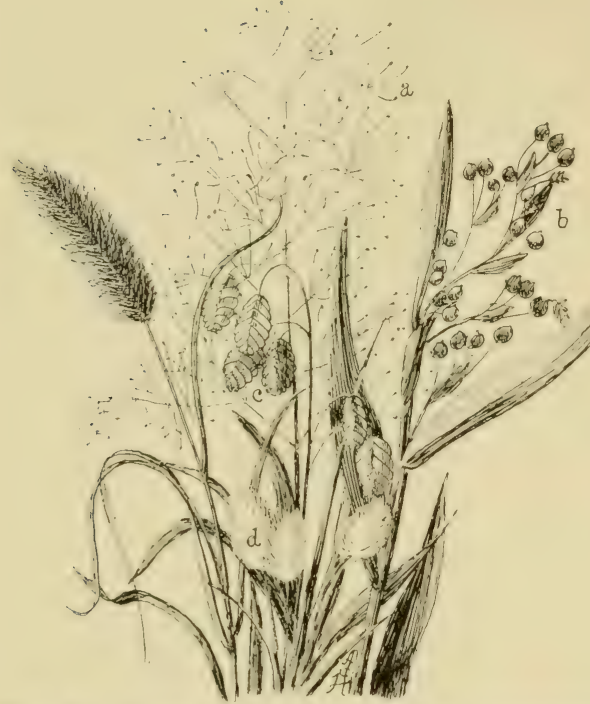

Fig. 47.- Some of the more popular ornamental grasses: A, Cloud Grass; B, Job's Tears; C, Quaking Grass; D, Hare's-tail Grass.
The ornamental parts of this grass-known as spikelets-are flat and either oval or heart-shaped. (See fig. 47 , c.) Even in the growing condition they appear as though pressed, and will retain this characteristic when used for the Winter bouquet. The seed may be sown in open soil. Let plants stand six or eight inches apart.

\section{Brome Grass- Bromus brizæ- formis}

- This has flattened, drooping spikelets somewhat resembling those of the Quaking Grass. (See fig. 47 , c.) The height is two feet; the plant is often a biennial.

\section{Coix lachryma-Job's Tears}

This grass produces curious pearly-grey seeds that hang from leaf-like sheaths. Each seed is about the size of a cherry stone and hard. (See fig. 47 , B.) They were often used as teething beads because mothers used to think that hahies were raised properly only when they had a string of these beads about their necks. Height, two to three feet; set plants 12 inches apart.

\section{Eragrostis interrupta (elegans) - Love Grass}

This is a grass closely resembling Agrostis when seen in masses. The spikelets are small and "dancing," and are useful for bouquets. Heigh $t$, two feet. 


\section{Hordeum jubatum-Squirrel-Tail Grass}

This is of interest because of its short, feathery heads of bloom. Sow in April and thin to one foot. Height, two to three feet.

\section{Lagurus ovatus-Hare's-Tail Grass}

Here is a short growing grass with white, downy tufts one to one and one-half inches long at the tips of the stems. It is useful as a low edging for other annuals. It is also good for bouquets. It prefers a sandy soil and grows 12 to 18 inches tall. (See fig. 47, D.)

\section{Pennisetum-Fountain Grass}

$P$. longistylum, two feet tall, has graceful, drooping, greenishwhite plumes. $P$. Ruppelianum, three feet high, has purple plumes and graceful green foliage. $P$. macrophyllum atrosanguineum has rich, coppery bronze foliage and plumes, and grows four feet high. $P$. japonirum is the tallest sort, attaining five feet.

Sow the seeds in frames in March, transplanting seedlings to small pots so the plants will not crowd. Allow 15 to 18 inches between plants when setting them out in May.

\section{Zea (Variegated)-Rainbow Corn}

A number of variations of the ordinary field corn are attractive materials for bold masses. In fact, they include the tallest annual grasses. The leaves are striped with yellow, white, red, or pink, and combine attractively with such cut flowers as Red-hot Pokers (Tritoma).

\section{EVERLASTINGS}

"Nay, cheer up, sister, life is not quite over, even if the year has done with Corn and Clover, with flowers and leaves; besides, in fact, it's true some leaves remain and some flowers, too, for me and you."

- Christina G. Rossettr.

A FTER flowers have bloomed in profusion all Summer, then comes A the frost and some are killed; a little later comes a real freeze and we are without flowers in our garden. We feel the lack of blossoms with which to grace our tables and mantelpieces, and it is then that we wish that we had raised some everlasting flowers. It is 
strange that every garden does not contain some sort of everlasting, especially since so few persons have greenhouses. Many delightful sorts may be grown.

With real flowers-both florist's sorts and home-grown everlastings-available for the Winter bouquet it is odd that some ingenious women will make parody flowers from waste paper and colored cloth; and it is shocking to find that less ingenious persons should buy the questionable, so-called artificial flowers. Generally the colors are gaudy and the structure of the flowers is no less absurd than would be an elephant with a tiger's head. You may have seen this sort of Roses colored like Zinnias, Nasturtiums with Violet leaves, Lilies of like oddity-but why stop to contemplate this awful perversion of taste? Especially when there are the everlastings?

\section{Classes of Everlastings}

There are four sorts of plants used as Everlastings, namely: annual everlasting flowers, perennial everlasting flowers, ornamental grasses and the decorative seed pods of various shrubs, weeds and garden plants.

Culture of Annual Everlastings. The various Everlastings may be given much the same treatment as other annuals. The seed may be sown indoors in March in order to get early plants, or the various sorts may be sown in the open soil when danger from frost is passed.

Picking. With but few exceptions the Everlastings are cut before they are fully open because in many cases it is the outside involucre which is straw-like and retains its colors. Allowed to open fully, Helichrysum and Acroclinium are not as attractive because the centers of the flowers become brown.

Drying. Before drying these flowers the leaves should be stripped from the stems and the latter hung upside down. If the stems are tied with string some will drop from the bunches as they shrink but if a rubber band is used it will tighten as the stems dry. If placed in vases immediately the stems absorb moisture from the air and the heads droop, and the stems wilt and become crooked. It is, therefore, wise to dry the flowers quickly and store them in a dry place until furnace heat is used.

It is, however, advisable to have some of the stems curve in order to add gracefulness to the vase arrangements. IV. C. Egan, in the "Standard Cyclopedia of Horticulture," writes of a method he has used to produce arching stems. "Take a long sheet of pliable cardboard eight inches wide, tack one edge lengthwise on the top of a 
shelf at the front, bringing it out and downward so as to form a half circle, and fasten it at the bottom. Then lay the freshly picked flowerstems on the shelf with the heads hanging down. It is sometimes necessary to place a weight on the stems to keep them in place."

\section{Acroclinium}

This is one of the smaller, daintier everlastings, growing 12 to 15 inches tall and bearing pink or white flowers with yellow centers. The flowers resemble those of Helichrysum but are smaller and rather more bell-shaped.

The plant is attractive in the garden and also useful as a source of cut flowers, which should be cut before they are fully open. It is properly classed as Helipterum roseum rather than Acroclinium which, however, is the more common name.

\section{Ammobium-Winged Everlasting}

This pretty little Everlasting has small white flowers with yellow centers. The plants are covered with silvery hairs and stiff, branched, winged stems. Few catalogs list this flower but it is well worthy of culture. It grows best in sandy soil.

\section{Catananche-Cupid's Dart}

One is amused to read that his plant was used by the ancient Greeks as one of the principle ingredients in their love potions. It is, strictly speaking, a perennial and is not, perhaps, properly included in this little book. The flowers are blue and white and resemble those of Cornflower but are hardly as handsome, although they have the advantage of being useful as Everlastings.

The plants grow two to three feet tall, and may be either raised from seed or divided. They prefer a sandy soil and should be set a foot and a half apart.

\section{Gomphrena-Globe Amaranth}

The tiny Clover-like flowers of this plant may be amaranth (true purple), white, or rose in color. They have frequently been called Bachelor's Buttons but this name is also applied to Centaurea and the double Buttercup. The plants grow one to two feet tall.

UsE. When the flowers have fully developed cut and dry them for Winter bouquets. The white sorts are not as clear and pure as 
the purple. Gomphrenas are attractive in the garden but the colors harmonize with few other shades; therefore they should be planted among white flowers. Their colors are heightened by the contrast.

Culture. Sow seed in early Spring as advised for other Everlastings, but as the seeds germinate slowly it is wise to soak them in hot water before sowing and to cover the soil during germination with grass clippings or a piece of burlap. Thin so that plants stand six to eight inches apart.

\section{Helichrysum-Strawflower}

The Strawflower is the largest and showiest of the Everlastings. Helichrysum bracteatum is the single type, but there are double forms cataloged as $H$. monstrosum. Named varieties in the various colors also are cataloged. The flowers range from white to yellow, crimson, pink, rose, chestnut, and rich purple. The darker shades are the most showy for Winter drying. The whites, though pretty when a few are grown, are too pale to produce brilliant effects. The plants grow two feet tall.

Use. Besides being useful as Winter flowers, they are really beautiful garden subjects. Remember to cut the blooms before they are open; even the small, undeveloped buds will open when dried.

Culture. It is usually wise to start these flowers early in a sunny window. Let the plants stand 12 inches apart.

\section{Helipterum}

The Everlastings listed in this little book as Acroclinium (page 99) and Rhodanthe (page 101), are also Helipterums but there is another sort known as Helipterum Humboldtianum which is but rarely

Fig. 48.- Strawflowers. The upper blossom is in the right condition to cut; the lower one is old, unshapely and worthless for a bouquet. seen, although of considerable interest. The flowers are small, yellow and arranged in terminal clusters. The foliage is grey. 


\section{Lunaria-Honesty}

Honesty is one of the old-fashioned Everlastings. Its main value is due to its large, silky, papery seed pods. The flowers are sweetscented but Cabbage-like in character; in general, the whole plant resembles a weed, but its seed pods are so interesting that it is worth growing. When the seed pods are thoroughly ripe the outer covering is shed and the skin-like partition through which the seeds may be seen, is disclosed. The fact that these partitions are transparent has given to the plant its names of Honesty and Honest Pocketbook. It is classed as both an annual and a perennial.

Culture. The plants grow well in shady places and are at home in ordinary garden soil as well as in the damper spots. Sow the seeds in the open ground early in order to allow time for a large number of seed pods to mature. Seed may be sown in Summer, in which case the plants will produce the seeds the following year. Let them stand eight inches apart.

\section{Rhodanthe-Swan River Everlasting}

The Rhodanthe (Helipterum Manglesii) is one of the slenderstemmed Everlastings. The flowers are rather bell-shaped, pink and white, and smaller than those of Helichrysum. The plants grow a foot tall and are dainty and graceful, but not showy.

UsE. For small basket and vase arrangements during the Winter, these little flowers are charming. They are raised by the acre in Europe where for years they have been popular. They are strongly recommended in the catalogs for pot plants in the Winter window.

Culture. The Rhodanthes are lovers of hot weather. The seed, if sown outdoors, should be planted only when the soil and air are warm. It is better not to move the plants but to thin them to stand six inches apart.

\section{Statice-Sea Lavender}

In order that this book may include all the various Everlastings several perennial sorts are included. Statice latifolia is a popular perennial sort growing two and a half feet tall with deep lavenderblue flowers borne in great profusion so as to form a mist-like mass of airy gracefulness a foot across. It has large, glossy, leathery leaves which lie upon the soil.

Statice sinuata is an annual sort with mauve or white flowers forming a one-sided spike 30 inches tall. The stems are winged. 
The leaves lie flat on the soil and are scalloped. S. Bonduellii has yellow flowers but resembles $S$. sinuata in growth.

UsE. The Statices lend the same grace to a bouquet as does Baby's Breath (Gypsophila). The lavender, deep blue, yellow, and white flowers are exceedingly useful and do not need to be placed in water.

Culture. Statices thrive in almost any soil but clay. Sow the seeds in the hotbed or a sunny window in March. When the seedlings are large enough prick them out in flats so that they stand two inches apart. The stems of the annual Statices are weak and require staking. If they are grown in rows bamboo stakes and string may be used. The following notes taken from a professional florists' journal are of interest:

"It should be mentioned that raising the seedlings is a somewhat tricky operation. The seed is sold in the form of the dried flowers. as it is impossible to free it from the flower tissues; it is small, much smaller than Aster seed, and black in color. The dried flower trusses are better for sowing if pulled apart, tedious task though it is. In any case, the flowers should be laid on their sides, not upright nor upside down, and just covered with soil. Inlike any other seed the writer is acquainted with, the radicle or rootlet appears from the top of the seed, not from the base where it is attached to the ovary. The rootlet pushes forth and, when it takes hold of the soil, pulls from the dead flower, two narrow leaflets which then push through the soil. It follows that the seedlings appear in bunches but as a general rule many of the flowers contain no seed, a fact easily understandable, as many of them are staminate or male flowers.

T. It will be realized that unless started on their sides, the young seedlings thaves small chance of freeing themselves from the mass of rubbish. If upside down they cannot get clear and if upright, the seed leaves are liable to rot before the rootlet can descend sufficiently to exert its pulling powers. The pricking off process must be done expeditiously, for if left longer than ten days or so after the seedlings appear, the decaying flowers will cause wholesale damping-off. The pricking off must be done before the rough leaf appears. A small label is a good tool to use for lifting the seedlings and the worker must carefully pull the seedlings from among the mass and plant them so that the seed leaves just clear the soil. The amount of root is, of course, infinitesimal but the worker must avoid setting any plants with broken roots. Usually the germination is good enough to allow one to be discriminating. After pricking off, keep the flat covered with glass for a few days and exercise care in watering. After the plants get hold, they can be treated the same as indoor raised Asters. The flowers should be cut only when dry, and do not have to be flaced in water."

\section{Xeranthemum-Immortelle}

The Xeranthemum is an interesting Everlasting with purple, lavender, pink, and white flowers. It grows three feet tall and produces its flowers in clusters. 
UsE. This and Catananche are the only blue or purple Everlasting flowers. As the foliage is light, silvery green these plants are interesting for the garden as well as for cutting.

Culture. Sow in the open in late April. Thin the plants to stand eight inches apart.

\section{Decorative Seed Pods}

Many of our weeds and garden flowers produce seed pods which are useful for combining with our Strawflowers and grasses in Winter bouquets. Although these pods are usually brown, they are of interesting forms. Among these plants are:

Cat-Tall. All are familiar with Cat-tails. Small bunches of them with their dried leaves, are attractive in tall, cylindrical vases.

Dоск. Several species of this common weed produce large, irregular clusters of winged seeds which are said to resemble ground coffee by boys and girls who collect them to "play store."

Evening Primrose. The seed pods of the Evening Primrose are borne in tall spires. They may be easily found along railroad tracks and in waste places. Each capsule is about an inch long and is four-parted at the top.

Globe Thistles (Eryngium). These perennials in our gardens bear greyish-green, globular, thistle-like heads that are interesting.

Goldenrod. Goldenrod dried quickly will retain its color for some months and for large mass effects is a dainty material.

GyPSOPHILA (Baby's Breath). For use as a dried flower in Winter the double form of the perennial Gypsophila is exceptionally "misty" and adds an airy grace to a bouquet.

Hydrangea. The large seed heads of the shrubby Hydrangea paniculata grandiflora are frequently cut and kept in Winter vases.

JIMSON WEED. This obnoxious, thorny weed has one good feature in that it produces interesting, decorative, thorny capsules.

Lunaria. This plant, which bears decorative seed pods, has already been discussed under the flowering Everlastings. (See page 101.)

MiLKweEd. There is no question about the decorative beauty of an opening Milkweed pod just as it scatters its seeds and sends its silken parachutes into the air. Unfortunately such seed pods are too messy for our homes. After the gauzy seeds are shed, however, the pods are exceedingly interesting, appearing like shells poised upon
the stems. 
Mullein. The farmer sees little to admire in these tall, majestic spires of seed capsules, but the city dweller may find them of interest for use in the house.

Plantain, Everlasting. Growing in most sections of our country are one or more species of everlastings with wooly grey leaves and small, creamy-white straw flowers. If gathered before the seeds ripen they have a real value for $W$ inter use.

Rose. Along our roadsides grow many species of Roses that bear clusters of Rose fruits or "hips" which can add color to an otherwise dull bouquet of dried flowers and seed heads.

Rose of Sharon. This shrub variously known as Hibiscus and Althæa, produces capsules which, while not attractive in color, are interesting in form.

RuE. In some gardens of herbs and collections of Skakespearean plants Rue is grown. The plants have a repugnant odor but the seed capsules are interesting. They are globular and cluster at the ends of the stiff stems.

Teazle (Fuller's Weed). The Teazles of our roadsides are prickly and forbidding but nevertheless interesting when Winter comes. It may be of interest to know that these spiny seed heads are used commercially for

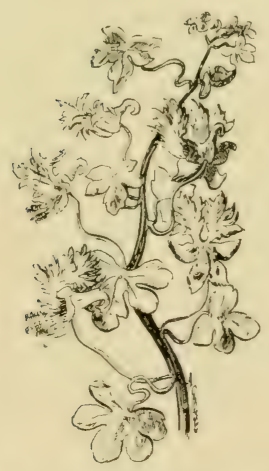

Fig. 49. - The amusing Canary Bird Vine is delightful. Like Nasturtium, it is a Tropæolum. combing the nap upon the finer woolens.

Velvet Leaf (Abutilon). In our rich garden soils there often spring up plants with heart-shaped leaves as smooth and velvety as a kitten's ear. The plants bear small yellow flowers which are followed by urn-shaped capsules, attractively crimped at the apex. These capsule-bearing stems are popular subjects for those who are fond of painting in ink.

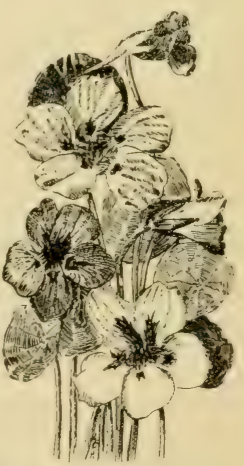

Fig. 50.-Nasturtiums provide abundant flowers, shade and seed pods for pickles. 


\section{ANNUAL VINES}

NE often desires a vine to shade a porch or hide an unsightly fence and one that will grow quickly. It is at such a time that the value of annual vines is appreciated. There are coarse sorts and dainty ones-types for every use.

Among the most popular vines are those described below:

\section{Balloon Vine, or Love-in-a-Puff-Cardiospermum}

This rapid-growing climber does best in warm situations. It has small white flowers and seed vessels that resemble tiny balloons an inch in diameter. The plants grow eight to ten feet tall and may be used in any place where vines are needed.

Culture. The seeds should be sown early in May in a light soil in a warm situation.

\section{Balsam Apple-Momordica}

The Balsam Apple is a remarkably handsome and ornamental vine, with beautiful dark green, lobed foliage and warty fruit. When ripe the fruit opens displaying the carmine interior.

Species. The Balsam Apple, M. Balsamina, grows 15 to 20 feet tall and has orange colored apple-shaped fruits. (See fig. 51, page 106.) The Balsam Pear, M. Charantia, grows about ten feet tall and has bright yellow pear-shaped fruit.

UsE. These vines are excellent for covering rockwork, trellises and stumps.

Culture. Sow the seed in light, rich soil, about May (or when the trees are starting out in leaf) at the base of the support upon which the vines are to climb.

\section{Canary Bird Vine}

The Canary Bird Vine, or Canary Creeper (Tropæolum peregrinum) is a rapid growing climber with canary-yellow blossoms resembling a bird with wings half expanded. The flowers are arranged in sprays.

UsE. The plant is used on trellises and as a screen to cover old fences. Except for its deeply cut petals and lobed leaves, it resembles Nasturtiums.

Culture. The plants should be started in pots indoors in March and planted out when all danger of frost is past. Seed may also be sown in the open border late in the Spring. 


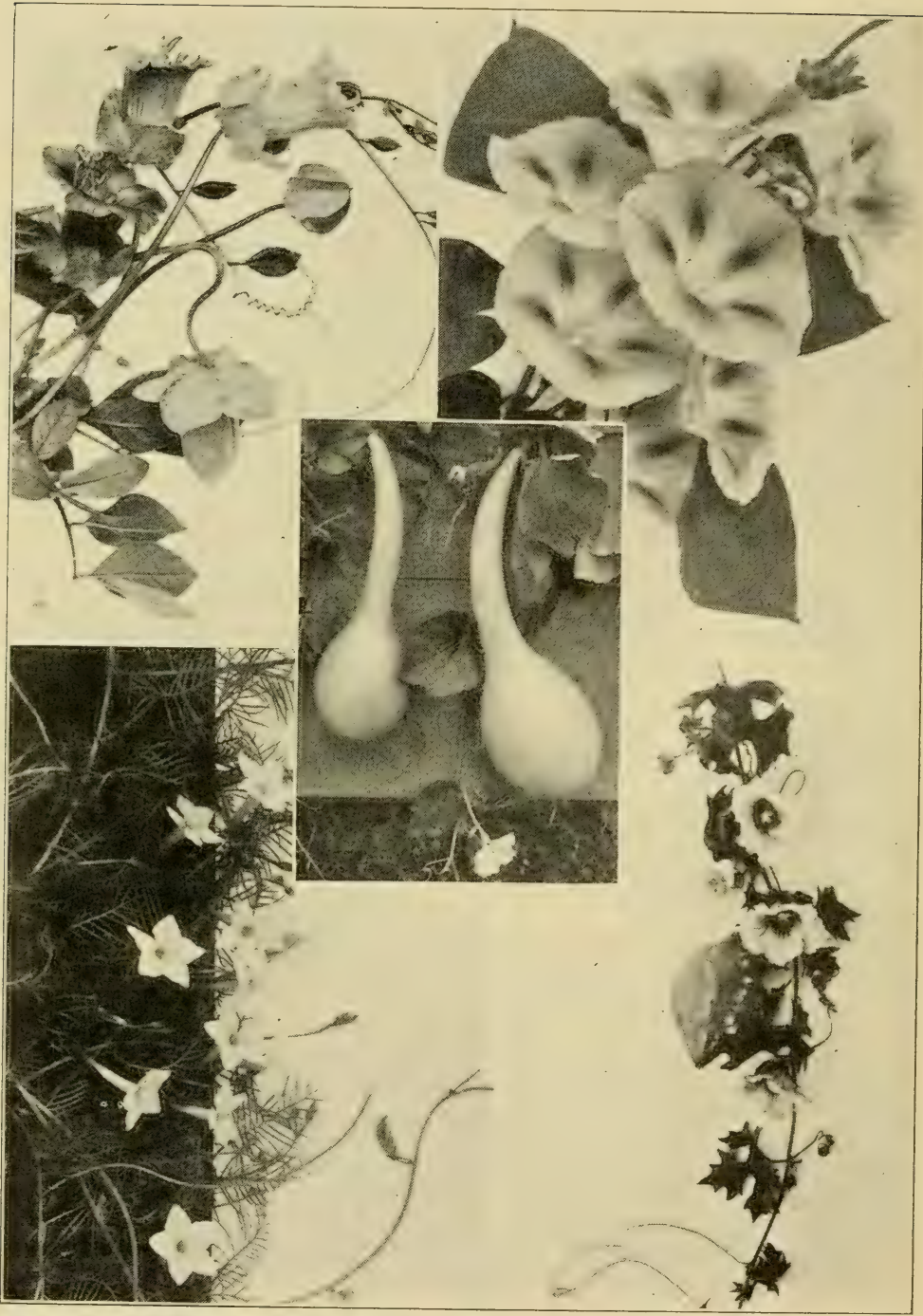

Fig. 51.-Upper left, Cobæa, a rapid climber of pleasing character; upper right, Morning Glory, an old kitchen porch favorite, but useful elsewhere, too; lout $r$ left, the Cypress Vine is graceful and has brilliant flowers; lower right, blossoms and an immature fruit of the interesting Balsam Apple; center, the Dipper Gourd combines oddity with usefulness. 


\section{Cardinal Climber}

The Cardinal Climber is a vine of great charm because of its bright red, Morning Glory-like flowers. The leaves are less finely lobed than those of the Cypress Vine. The vines grow 10 to 20 feet and flower all season long. The seeds had best be soaked in hot water for a day before they are sown.

\section{Cobæa-Cup-and-Saucer Vine}

This rapid growing vine, Cobæa scandens, is most attractive. Although not an annual it is so treated in the North. The vines attain a height of 30 feet and the flowers are large and bell-shaped, ranging in color from pink to purple. They are followed by plum-shaped fruits.

Culture. Sow the seeds in April, one to a pot. Press them into the soil edgewise, as they are large and flat, and germinate poorly when placed broad side down.

\section{Wild Cucumber-Echinocystis}

The Wild Cucumber is one of our fastest growing vines. The common species, Echinocystis lobata, has light green leaves. The white flowers appear during July and August and are followed by an abundance of long, spiny seed pods. The plants grow from eight to thirty feet tall.

The vines may be grown on trellises or for covering old trees and fences. They are not greatly admired by the author because of the spiny seed pods.

The seeds may be sown in Autumn, in which case they should be nicked. If sown in Spring they should first be soaked in warm water. They will grow in any soil.

\section{Cypress Vine}

This is one of the daintiest of vines having fine, fern-like foliage and being dotted with small, star-shaped flowers-orange, scarlet, and white in color. (See fig. 51, page 106.)

It is very desirable for covering small, ornamental trellises. It is also a good climber to grow in pots during the Winter, or anywhere that graceful foliage is desired. It grows from fifteen to twenty feet high.

The seeds should be sown in May. They are so hard that germination takes place only when the seed coats are cut or filed and the seeds soaked in warm water.

These vines enjoy light soil and a sunny location. 


\section{Gourds}

The Gourds are novel annual climbers with ornamental foliage and singularly shaped fruits which are often strangely colored and marked.

The following are especially odd and are the ones most commonly cataloged:

DIPPER-SHAPED. If this variety is grown on the ground its fruits will be of a different shape than if it is supported on a trellis. The fruit is slender and neck-like for two-thirds of its length and then widens into the form of a bowl. (See fig. 51, page 106.)

Hercules' Club. This bears the largest of any of the Gourds, the fruits growing to a length of four feet.

Disнсцотн. The sponge-like, porous pulp dried and used as a dishcloth or sponge gives excellent results.

Pear-Shaped. The striped fruits of this variety are very pretty.

SERPEnt-Shaped. The fruit is three to five feet long and very slender. It is striped like a reptile and becomes carmine when ripe.

Other interesting shapes are produced by the Egg, the Lemon, the Orange, the Apple and the Pipe Gourds.

UsE. Gourds are grown in America mostly for their unique fruits, and for covering trellises, old stumps and fences. In Japan, the tough fiber on the inside is used for the soles of sandals. In tropical countries, the shells are dried and used for dishes and drinking vessels. The Pipe Gourd is used in making Calabash pipe bowls.

Culture. Gourd plants are exceptionally free from insect pests. Plant them six inches apart. Do not transplant, but sow the seed where the plants are to grow.

\section{Hop Vine-Humulus}

The Japanese Hop Vine, Humulus japonicus, is a rapid climber, attaining a height of 20 to 30 feet. It is much prettier than the common Hop, its luxuriant foliage making a dense ornamental covering. $H$. japonicus var. variegatus is a form with variegated leaves that is preferred by some persons.

The Japanese Hop is one of the best for covering verandas and trellises. Sow in light, rich soil at the base of the support upon which it is to climb. Heat or drought do not affect it, and it is not bothered by insects. 


\section{Hyacinth Bean-Dolichos}

This rapid-growing, twining climber flowers freely. The flowers are purple to snow white, pea-shaped, and followed by purple seed pods. The foliage is heart-shaped and bright green.

There are several good varieties of the species, which is Dolichos Lablab. Daylight, which was introduced from Japan, grows ten feet tall, and has snow white flowers. Darkness is identical in every way with the above, except that the flowers and seed pods are rich purple in color.

UsE. These vines are used as a screen, on trellises, or wherever a rapid growing vine is wanted.

Culture. Plant in May where the vines are to grow and provide strings for them to twine around. The vines do not transplant well, but they are not affected by pests.

\section{Morning Glory-Convolvulus}

In the beauty and delicacy of its brilliant flowers, the Morning Glory is unsurpassed, provided good sorts are chosen.

Species. The common Morning Glory, Ipomæa purpurea, is commonly known as Convolvulus major. It is free flowering and grows rapidly to a height of 15 feet. The flowers come in all colors, the blues heing particularly attractive. (See fig. 51 , page 106.)

UsE. This vine may be used on trellises, arbors, verandas, or to cover any unsightly object. Much of the unpopularity of the Morning Glory in recent years has resulted from the fact that persons have allowed their Morning Glories to self sow and have, therefore, only the poorest colors, and smaller-flowering vines, which are often little better than weeds.

Culture. The vine thrives in almost any soil or situation. To hasten germination soak the seed in warm water for from one to two hours before sowing.

\section{Nasturtium-Tropæolum}

The popularity of the Nasturtium is chiefly due to the fact that it is an elegant and luxurious climber with lustrous foliage and profuse flowers of many colors-pale primrose-yellow, geranium-scarlet, deep scarlet, sulphur-blotched red, orange, creamy white, brilliant salmon, deep garnet, orange, and vermilion. (See fig. 50, page 104.) 
Species. The common species is Tropæolum majus, but the best colors will be found in T. Lobbianum. Both species are very rapid growers, quickly reaching a height of 15 feet.

Use. The vines may be used as bedding plants if the runners are pinned down. They are also unexcelled for verandas, trellises, to cover old stumps, fences, rough ground, or any unsightly object. The seed pods may be picked while green and put up in vinegar for pickles. Every gardener knows that the Nasturtium is without a rival as a cut flower. The more freely the flowers are cut the more freely they will be produced.

Culture. Sow outside when the ground is warm, as the seeds will rot in cold, damp soil. A rather poor soil is best as the vines will produce many leaves and but few flowers in rich ground. These vines are of easiest culture requiring almost no care after being sown.

If the plants become affected with black lice, spray them with some form of tobacco extract.

\section{Scarlet Runner Bean-Phaseolus}

This Bean (Phaseolus multiflorus) has attractive Pea-like flowers of a brilliant scarlet that are followed by an abundant crop of beans. During the war many persons planted this vine for beauty and ate the beans.

Culture. The plant is of easy culture. Sow the seeds at the base of the trellis upon which they are to grow, when the soil is warm and frosts are passed.

\section{Thunbergia-Black-Eyed-Susan Vine}

This is a low-growing climber with perky, black-eyed flowers which in the commonest species (Thunbergia alata) are yellowish buff in color. T. alata alba has white flowers and those of $T$. aurantiaca are orange with a characteristic dark eye. None of the species ever attain a height of over six feet, and, unless encouraged to climb, will grow downward or along the ground.

UsE. This tendency to trail indicates the value of the plant for hanging baskets, porch boxes and in rockeries. In all these places it is highly effective, but especially in the last named, because of the rustic appearance of the vine.

Culture. The seeds of Thunbergia may be sown outdoors where they are to grow, but it is better to start them indoors in April. 


\title{
INDEX OF PLANT NAMES
}

\author{
(Figures in italics indicate illustrations.)
}

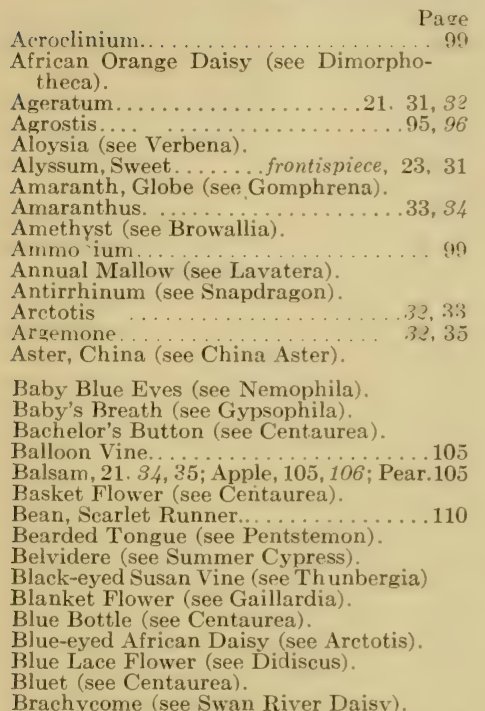

Brachycome (see Swan River Daisy)

Briza....................95, 96

Bromus. . . . . . . . . . . . . . . . . 96

Browallia.................... . . 32, 35

Burning Bush (see Summer Cypress).

Bush Eschscholtzia (see Hunnemannia).

Butterfly Flower (see Schizanthus).

Cacalia (see Emilia).

Calendula................34, 36

California Poppy (see Eschscholtzia).

Calliopsis ...................... 87

Callistephus (see China Aster).

Canary Bird Vine............104, 105

Candytuft.......................... 40

Cardinal Climber.................. 107

Cardiospermum (see Balloon Vine).

Castor Bean... . . . . . . . . . . . . . 38

Catananche. . . . . . . . . . . . . . . . . . . . . 99

Celosia..................... 39, 40

Centaurea.................23,41,42

China Aster................ 23 42, 43, 44

Chinese Lantern Plant (see Physalis)

Chrysanthemum..............21. 47

Clarkia...................23, 47, 48

Cleome.................... 48,49

Cobra................... 106, 107

Cockscomb (see Celosia).
Coix Page

Convolvulus (see Morning Glory) 65.96

Coreopsis (see Calliopsis).

Corn Flower (see Centaurea).

Cosmos........................ 49

Cucumber, Wild ................... 107

Cupid's Dart (see Catananche).

Cypress, Summer (see Summer Cypress).

Cypress Vine. .............106, 107

Daisy, African Orange (see Dimorphotheca; Swan River (see Swan River Daisy).

Datura....................50,52

Delphinium (see Larkspur).

Devil-in-the-Bush (see Nigella).

Dianthus (see Pinks).

Didiscus..................50,5l

Dimorphotheea................51, 55

Dolichos (see Hyacinth Bean).

Echinocystis (see Cucumber Vine).

Egyptian Rose (see Scabiosa).

Enilia.

Eragrostis.......................... 96

Eschscholtzia, 52, 53 ; Bush, (see Hunnemannia).

Euphorbia.

Evening Frmrose (see CEnothera),

Everlastings. .

Farewe'l-to-Spring (see Godetia).

Fennel Flower (see Nigella).

Fig Marigold (see Mesembryanthemum).

Fire Bush (see Summer Cypress).

Fire-on-the-Mountain (see Euphorbia).

Flax (see Linum).

Flora's Paint Brush (see Emilia).

Floss Flower (see Ageratum).

Flower-of-7n-Hour (see Hibiscus).

Fountain Plant (see Amaranthus).

Four o'Clock .............51, 54

Gaillardias................... 51,51

Giant Yellow Tulip Poppy (see Hunnemannia).

Gillyflower (see Stock).

Globe Amaranth (see Gomphrena).

Godetia..................55,56

Golden Wave (see Calliopsis).

Gomphrena... . . . . . . . . . . . . . . . 99

Gourds. . . . . . . . . . . . . . . . 106, 108

Grasses, Ornamental. ............ 95

Gypsophila...................... 57

Helianthus (see Sunflower).

Helichrysum. . . . . . . . . . . . . . . 100

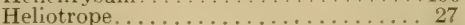

Helipterum... . . . . . . . . . . . . . . . 100

Hibiscus . . . . . . . . . . . . . . . . 57 
Hollyhock, Trailing (see Hibiscus).

Honesty (see Lunaria).

Hordeum................... .96,97

Hop Vine......................... 108

Humulus (see Hop Vine).

Hunnemannia................55, 58

Hyacinth Bean. ..................... 109

Iberis (see Candytuft).

Ice Plant (see Mesembryanthemum).

Immortelle (see Xeranthemum).

Impatiens (see Balsam).

Jack-in-the-Bush (see Nigella).

Job's Tears (see Coix).

Joseph's Coat (see Amaranthus).

Kochia (see Summer Cypress).

Lady-in-the-Green (see Nigella).

Lady Slipper (see Balsam).

Lagurus . . . . . . . . . . . . . . . . . . . . 97

Larkspur..............................

Lathyrum (see Sweet Peas).

Lavatera.................. 56,59

Linum............................. 6,59

Lippia (see Verbena).

Lobelia................... 60

Love Grove (see Nemophila).

Love-in-a-Mist (see Nigella); -in-a-Puff (see Balloon Vine); -Lies Bleeding (see Amaranthus).

Lunaria............ . . . . . . . . . . 101

Lupines (Lupinus) . . . . . . . . . . . 23, 61

Maiden-in-the-Green (see Nigella).

Malcomia (see Virginian Stock).

Mallow, Annual (see Lavatera).

Marigold.

Iarshmallow (see Hibiscus).

Marvel of Peru (see Four o'Clock).

Matthiola (see Stock).

Iresembryanthemum...

Mexican Fire Plant (see Euphorbia and Summer Cypress); Poppy (see Argemone).

Mignonette...................68

Mimosa................6. 64

Mimulus................6. 64

IIrabilis (see Four o'Clock).

Momordica (see Balsam Apple).

Ionkey Flower (see Mimulus).

Iorning Glory, Dwarf, 65; Tall.... .106, 109

Mourning Bride (see Scabiosa).

Musk Plant (see Mimulus).

Nasturtium................104, 108

Nemophila.......................... 66

Nicotiana..................... 66,67

Nigella.................... 67, 68

Enothera....................68

Ornamental Grasses (see Grasses); Tobacco (see Nicotiana).

Painted Daisy (see Chrysanthemum); Leaf (see Euphorbia); Tongue (see Salpiglossis).

Pansy....

.23. $65, \tau 0$

Papaver................. 76, 77

Pennisetum.................. 97

Pentstemon............... 71 , ít

Perilla..

21. 72

Petunia

$21,70,72$
Phacelia................ 21, 73

Phaseolus (see Scarlet Runner Bean).

Phlox ...............21, 73, it

Physalis........................ 75,76

Pincushion Flower (see Scabiosa).

Pinks................... 75, 76

Poinsettia, Annual (see Euphorbia).

Poor Man's Orchid (see Schizantbus).

Poppy, California (see Eschscholtzia); Giant Yellow Tulip, (see Hunnemannia); Mexican, (see Argemone); Opium, (see Papaver); Prickly, (see Argemone); Shirley, (see Papaver).

Portulaca.

Pot Marigold (see Calendula).

Primrose, Evening (see (Enothera).

Prince's Feather (see Amaranthus).

Ragged Sailor (see Centaurea).

Reseda (see Mignonette).

Rhodanthe. 77, is

Ricinus (see Castor Bean.)

Rose Moss (see Portulaca).

Sage (see Salviı).

Salpiglossis.

Salvia............................. 79

Sanvitalid......................... 80

Satin Florer (see Godetia).

Scabiosa, sweet Scabious........... 78,80

Schizanthus................... 231, 82

Sea Lavender (see Statice).

Sensitive Plant (see Mimosa).

Seven Sisters (see Portulaca).

Snapdragon.

Snow-on-the-1Ioun tain (see Euphorbia)

Spider Flower, Giant (see Cleome).

Spurge (see Euphorbia).

Statice...

Stock, 82, 83; Virginian.

Strawflower (see Helichrysum)

Sultan, Sweet (see Centaurea).

Summer Cypress................ . 88, 84

Sunflower........................... 84

Sun Plant (see Portulaca).

Swan River Daisy, 85; Everlasting (see Rhodanthe).

Sweet Alyssum (see Alyssum); Peas, 86, 90; Scabious (see Scabiosa); Sultan (see Centaurea).

Tagetes (see Marigold)

Tassel Flower (see Emilia).

Texas Pride (see Phlox).

Thunbergia.

Tobacco, Ornamental (see Nicotiana).

Torenia.......................... 92

Trachymene (see Didiscus).

Tropæolum (see Canary Bird Vine and Nasturtium)

Trumpet Flower (see Datura).

Verbena, 21, 90, 92; Lemon. . . . . . . . 9.93

Virginian Stock................ 90.93

Winter Cherry (see Physalis).

Wishbone Flower (see Torenia).

Woolflower (see Celosia).

Yeranthemum..

Youth and Old Age (see Zinnia).

Zea...................... 97

Zinnia................... 93 


\section{TABULAR CULTURAL INDEX}

\section{(For Synonyms See Preceding Index of Plant Names.)}

\begin{tabular}{|c|c|c|c|c|}
\hline Species or variety & Page & Height & $\begin{array}{l}\text { Thin to } \\
\text { (inches) } \\
\text { apart }\end{array}$ & $\begin{array}{l}\text { Color or } \\
\text { other } \\
\text { feature }\end{array}$ \\
\hline 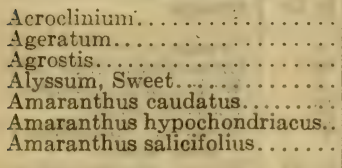 & $\begin{array}{l}99 \\
31 \\
95 \\
31 \\
33 \\
33 \\
33\end{array}$ & $\begin{array}{l}12 \text { to } 15 \mathrm{in} . \\
6 \text { to } 24 \mathrm{in} . \\
18 \mathrm{in.} \\
8 \mathrm{in} . \\
5 \text { to } 6 \mathrm{ft} . \\
4 \text { to } 5 \mathrm{ft} . \\
3 \mathrm{ft} .\end{array}$ & $\begin{array}{l}8 \text { to } 10 \\
6 \text { to } 9 \\
6 \text { to } 8 \\
6 \text { to } 8 \\
15 \text { to } 18 \\
15 \text { to } 18 \\
15 \text { to } 18\end{array}$ & $\begin{array}{l}\text {, white } \\
\text { white } \\
\text { imental grass } \\
\text { te } \\
\text { wers) red } \\
\text { wers) purplish-red } \\
\text { ves) bronze green }\end{array}$ \\
\hline Amaranthus tricolor....... & 33 & 18 to 24 in. & 15 to 18 & $\begin{array}{l}\text { e red } \\
\text { let, green, } \\
\text { d white }\end{array}$ \\
\hline & $\begin{array}{l}99 \\
33\end{array}$ & $\begin{array}{l}12 \text { to } 18 \mathrm{in} . \\
\quad 24 \mathrm{in.}\end{array}$ & $\begin{array}{l}6 \text { to } 8 \\
12 \text { to } 18\end{array}$ & $\begin{array}{l}\text { White, } \\
\text { White, steel blue cen- } \\
\text { ter }\end{array}$ \\
\hline $\begin{array}{l}\text { rgemone grandiflora.......... } \\
\text { rgemone mexicana......... }\end{array}$ & $\begin{array}{l}35 \\
35\end{array}$ & $\begin{array}{l}36 \text { in. } \\
36 \text { in. }\end{array}$ & & $\begin{array}{l}\text { White } \\
\text { Yellow }\end{array}$ \\
\hline$\ldots \ldots \ldots \cdots \cdots$ & $\begin{array}{r}105 \\
35\end{array}$ & $\begin{array}{l}8 \text { to } 10 \mathrm{ft} . \\
18 \text { to } 24 \mathrm{in.}\end{array}$ & $\begin{array}{l}15 \text { to } 18 \\
12 \text { to } 18\end{array}$ & $\begin{array}{l}\text { ss" } \\
\text { salmon, }\end{array}$ \\
\hline alsam Apple............. & $\begin{array}{r}105 \\
105 \\
110 \\
95 \\
95 \\
96 \\
35\end{array}$ & $\begin{array}{l}15 \text { to } 20 \mathrm{ft} . \\
10 \mathrm{ft} . \\
5 \text { to } 6 \mathrm{ft} . \\
18 \mathrm{in.} \\
12 \mathrm{in.} \\
24 \mathrm{in} . \\
18 \mathrm{in} .\end{array}$ & $\begin{array}{l}\text { Specimen } \\
\text { Specimen } \\
8 \text { to } 12 \\
6 \text { to } 8 \\
6 \text { to } 8 \\
6 \text { to } 8 \\
6 \text { in. }\end{array}$ & $\begin{array}{l}\text { (Fruit) orange } \\
\text { (Fruit) yellow } \\
\text { Scarlet } \\
\text { Ornamental grass } \\
\text { Ornamental grass } \\
\text { Ornamental grass } \\
\text { Blue, white }\end{array}$ \\
\hline Calliopsis tinctoria... & $\begin{array}{l}36 \\
36 \\
36\end{array}$ & $\begin{array}{l}12 \text { to } 18 \mathrm{in} \\
18 \mathrm{in} . \\
36 \mathrm{in} .\end{array}$ & $\begin{array}{r}12 \text { to } 15 \\
8 \text { to } 12 \\
8 \text { to } 12\end{array}$ & $\begin{array}{l}\text { Gold, lemon, sulphur } \\
\text { Golden yellow thin } \\
\text { Yellow, marked with } \\
\text { mahogany }\end{array}$ \\
\hline & $\begin{array}{r}105 \\
37\end{array}$ & $\begin{array}{l}4 \text { to } 6 \mathrm{ft} \text {. } \\
12 \text { to } 18 \mathrm{in} \text {. }\end{array}$ & $\begin{array}{c}12 \text { to } 18 \\
6 \text { to } 8\end{array}$ & lav- \\
\hline & $\begin{array}{r}107 \\
38\end{array}$ & $\begin{array}{l}10 \text { to } 20 \mathrm{ft} . \\
3 \text { to } 12 \mathrm{ft} .\end{array}$ & $\begin{array}{l}\text { Clumps } \\
24 \text { in. }\end{array}$ & $\begin{array}{l}\text { Cardinal } \\
\text { (Leaves) gr } \\
\text { ple, maroo }\end{array}$ \\
\hline rgentea (plumosa) & $\begin{array}{l}99 \\
39 \\
39 \\
39\end{array}$ & $\begin{array}{l}12 \mathrm{in} . \\
30 \text { to } 36 \mathrm{in} . \\
24 \mathrm{in} . \\
8 \text { to } 24 \mathrm{in} .\end{array}$ & $\begin{array}{c}8 \text { to } 12 \\
24 \\
24 \\
24\end{array}$ & $\begin{array}{l}\text { Blue, white } \\
\text { Gold, pink, crimson } \\
\text { Crimson } \\
\text { Crimson, golden yel- }\end{array}$ \\
\hline $\begin{array}{l}\text { Centaurea americana... } \\
\text { Centuarea cyanea...... }\end{array}$ & $\begin{array}{l}41 . \\
41\end{array}$ & $\begin{array}{l}36 \text { in. } \\
24 \text { in. }\end{array}$ & $\begin{array}{r}12 \\
6\end{array}$ & $\begin{array}{l}\text { Rosy lavender } \\
\text { Blue, purple, rose, }\end{array}$ \\
\hline $\begin{array}{c}\text { Centaurea imperialis (mos- } \\
\text { chata).................... }\end{array}$ & 41 & 24 in. & 8 to 12 & White, pink, yellow, \\
\hline China Aster & 42 & 24 in. & 12 & $\begin{array}{l}\text { lavender, purple } \\
\text { Rose pink, white, vio- } \\
\text { let, purple, pink, } \\
\text { lavender }\end{array}$ \\
\hline Chrysanthemum carinatum & 47 & 24 in. & 12 & $\begin{array}{l}\text { White and purple, } \\
\text { yellow }\end{array}$ \\
\hline
\end{tabular}




\section{Tabular Gultural Index-Continued}

\begin{tabular}{|c|c|c|c|c|}
\hline Species or variety & Page & Height & $\begin{array}{l}\text { Thin to } \\
\text { (inches) } \\
\text { apart }\end{array}$ & $\begin{array}{l}\text { Color or } \\
\text { other } \\
\text { feature }\end{array}$ \\
\hline 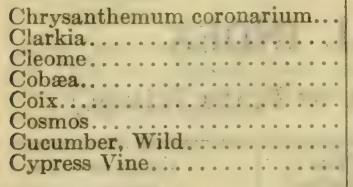 & $\begin{array}{r}47 \\
48 \\
48 \\
107 \\
96 \\
49 \\
107 \\
107\end{array}$ & $\begin{array}{l}36 \mathrm{in} . \\
24 \text { in. } \\
3 \text { to } 4 \mathrm{ft} \text {. } \\
30 \mathrm{ft} \text {. } \\
24 \text { to } 36 \mathrm{in} \text {. } \\
3 \text { to } 6 \mathrm{ft} \text {. } \\
8 \text { to } 30 \mathrm{ft} \text {. } \\
15 \text { to } 29 \mathrm{ft} \text {. }\end{array}$ & $\begin{array}{l}7 \text { to } 9 \\
24 \\
\text { Clumps } \\
12 \\
24 \text { to } 36 \\
6 \text { to } 8 \\
\text { Clumps }\end{array}$ & $\begin{array}{l}\text { Yellow } \\
\text { Rose, lilac, pink, white } \\
\text { Pink } \\
\text { Pink, purple } \\
\text { Ornamental grass } \\
\text { White, pink, crimson } \\
\text { White } \\
\text { Scarlet }\end{array}$ \\
\hline 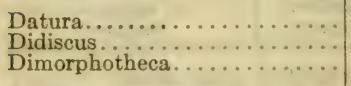 & $\begin{array}{l}50 \\
50 \\
51\end{array}$ & $\begin{array}{l}24 \text { to } 36 \text { in. } \\
24 \text { in. } \\
12 \text { to } 15 \mathrm{in} .\end{array}$ & $\begin{array}{c}18 \\
12 \\
12 \text { to } 18\end{array}$ & $\begin{array}{l}\text { White, purple, yellow } \\
\text { Blue } \\
\text { Orange }\end{array}$ \\
\hline 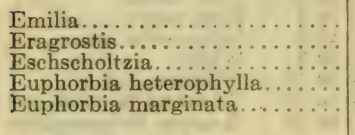 & $\begin{array}{l}51 \\
96 \\
53 \\
53 \\
53\end{array}$ & $\begin{array}{l}18 \mathrm{in} . \\
24 \mathrm{in.} \\
12 \mathrm{in} . \\
24 \text { to } 36 \text { in. } \\
24 \text { to } 36 \mathrm{in} .\end{array}$ & $\begin{array}{l}4 \\
6 \text { to } 8 \\
8 \\
18 \\
18\end{array}$ & $\begin{array}{l}\text { Orange } \\
\text { Ornamental grass } \\
\text { White, pink, orange } \\
\text { (Leaves) scarlet } \\
\text { (Leaves) margined } \\
\text { with white }\end{array}$ \\
\hline Four o'Clock ............... & 54 & 24 in. & 12 to 24 & White, crimson,y \\
\hline Gaillardia............... & 54 & $18 \mathrm{in.}$ & 12 & $\begin{array}{l}\text { Yellow and rosy pur- } \\
\text { ple }\end{array}$ \\
\hline Godetia amœena : & 55 & 12 to 24 in. & 12 & \\
\hline Godetia grandiflora.......... & 55 & 6 to 12 in. & 12 & $\begin{array}{l}\text { Rose and white, scar- } \\
\text { let, dark crimson, } \\
\text { white }\end{array}$ \\
\hline & $\begin{array}{r}99 \\
108\end{array}$ & $\begin{array}{l}12 \text { to } 24 \mathrm{in} . \\
3 \text { to } 5 \mathrm{ft} \text {. }\end{array}$ & $\begin{array}{l}6 \text { to } 8 \\
12 \text { to } 18\end{array}$ & $\begin{array}{l}\text { Amaranth, pink, white } \\
\text { (Fruits) oddly shaped, } \\
\text { marked and colored }\end{array}$ \\
\hline ypsophila . . . & 57 & $18 \mathrm{in.}$ & 8 to 12 & \\
\hline Helichrysum............... & 100 & 24 in. & 12 & $\begin{array}{l}\text { Yellow, scarlet, pink, } \\
\text { white }\end{array}$ \\
\hline $\begin{array}{l}\text { hot. } \\
u m \ldots \ldots \\
\cdots \ldots \ldots \\
\ldots \ldots\end{array}$ & $\begin{array}{r}100 \\
57 \\
57 \\
97 \\
108\end{array}$ & $\begin{array}{l}18 \mathrm{in} . \\
48 \mathrm{in.} \\
24 \mathrm{in} . \\
24 \text { to } 36 \mathrm{in} . \\
20 \text { to } 30 \mathrm{ft} .\end{array}$ & $\begin{array}{c}6 \text { to } 8 \\
24 \\
18 \\
12 \\
\text { Specimen }\end{array}$ & $\begin{array}{l}\text { Yellow } \\
\text { Yellow and maroon } \\
\text { Yellow, white } \\
\text { Ornamental grass } \\
\text { (Leaves) green and } \\
\text { white }\end{array}$ \\
\hline & $\begin{array}{r}58 \\
109\end{array}$ & & & $\begin{array}{l}\text { Yellow } \\
\text { White, purple }\end{array}$ \\
\hline & $\begin{array}{l}97 \\
58\end{array}$ & $\begin{array}{l}12 \text { to } 18 \text { in. } \\
24 \text { in. }\end{array}$ & $\begin{array}{c}6 \\
8 \text { to } 12\end{array}$ & $\begin{array}{l}\text { Ornamental grass } \\
\text { White, pink, scarlet, } \\
\text { blue, purple }\end{array}$ \\
\hline 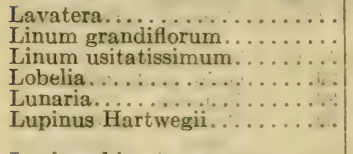 & $\begin{array}{r}59 \\
59 \\
59 \\
60 \\
101 \\
61\end{array}$ & $\begin{array}{l}30 \mathrm{in.} \\
12 \mathrm{in.} \\
36 \mathrm{in.} \\
4 \mathrm{in.} \\
24 \mathrm{in.} \\
24 \text { to } 36 \mathrm{in} .\end{array}$ & $\begin{array}{l}24 \\
8 \text { to } 12 \\
12 \\
8 \\
12 \text { to } 18 \\
12\end{array}$ & $\begin{array}{l}\text { Pink } \\
\text { Scarlet } \\
\text { Blue } \\
\text { Blue, white } \\
\text { Purple } \\
\text { Blue and red, blue } \\
\text { and white }\end{array}$ \\
\hline & $\begin{array}{l}61 \\
61\end{array}$ & $\begin{array}{l}24 \text { to } 36 \text { in. } \\
24 \text { to } 36 \text { in. }\end{array}$ & 12 & $\begin{array}{l}\text { Blue } \\
\text { Yellow }\end{array}$ \\
\hline & $\begin{array}{l}62 \\
63\end{array}$ & $\begin{array}{l}6 \mathrm{in} . \\
12 \text { to } 18 \mathrm{in} .\end{array}$ & 8 to 12 & $\begin{array}{l}\text { White, light rose } \\
\text { White, brownish yel- } \\
\text { low }\end{array}$ \\
\hline 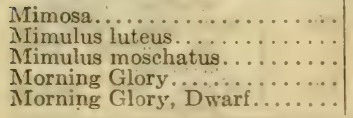 & $\begin{array}{r}64 \\
64 \\
64 \\
109 \\
65\end{array}$ & $\begin{array}{l}\text { Trailing } \\
12 \text { in. } \\
12 \mathrm{in.} \\
15 \mathrm{ft} . \\
\text { Trailing }\end{array}$ & $\begin{array}{l}12 \\
18 \\
12 \\
12 \\
12\end{array}$ & $\begin{array}{l}\text { Pink } \\
\text { Yellow and crimson } \\
\text { Yellow } \\
\text { Various } \\
\text { Blue, pink, purple }\end{array}$ \\
\hline
\end{tabular}




\section{Tabular Gultural Index - Continued}

\begin{tabular}{|c|c|c|c|c|}
\hline Species or variety & Page & Height & $\begin{array}{l}\text { Thin to } \\
\text { (inches) } \\
\text { apart }\end{array}$ & $\begin{array}{l}\text { Color or } \\
\text { other } \\
\text { feature }\end{array}$ \\
\hline 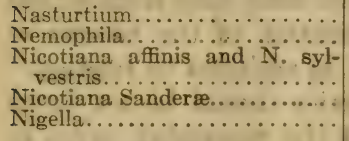 & $\begin{array}{l}67 \\
67 \\
67\end{array}$ & $\begin{array}{l}8 \text { to } 19 \mathrm{ft} . \\
6 \mathrm{in.}\end{array}$ & $\begin{array}{l}24 \\
24 \\
8 \text { to } 12\end{array}$ & $\begin{array}{l}\text { Various } \\
\text { Blue, white, purple } \\
\text { White } \\
\text { Pink } \\
\text { Blue, white }\end{array}$ \\
\hline $\begin{array}{l}\text { Enothera America .... } \\
\text { CEnothera Drummondii ......... } \\
\text { CEnothera mexicana (rosea) .... }\end{array}$ & $\begin{array}{l}68 \\
68 \\
68\end{array}$ & $\begin{array}{l}12 \text { to } 24 \mathrm{in} . \\
12 \text { to } 24 \mathrm{in} . \\
12 \text { to } 24 \mathrm{in} .\end{array}$ & $\begin{array}{l}8 \text { to } 12 \\
8 \text { to } 12 \\
8 \text { to } 12\end{array}$ & $\begin{array}{l}\text { White } \\
\text { Yellow } \\
\text { Rose }\end{array}$ \\
\hline $\begin{array}{l}\text { Pansy } \ldots \text { Rhoeas } \ldots \ldots \ldots \ldots \\
\text { Papaver } \\
\text { Papaver somniferum } \\
\text { Pennisetum.................... }\end{array}$ & $\begin{array}{l}68 \\
76 \\
76 \\
97\end{array}$ & $\begin{array}{l}6 \mathrm{in} \\
24 \text { to } 36 \mathrm{in} . \\
18 \text { to } 24 \mathrm{in} . \\
2 \text { to } 5 \mathrm{ft} \text {. }\end{array}$ & $\begin{array}{l}6 \text { to } 8 \\
6 \text { to } S \\
12\end{array}$ & $\begin{array}{l}\text { Various } \\
\text { Various } \\
\text { Various } \\
\text { Grass; bronze and } \\
\quad \text { green leaves }\end{array}$ \\
\hline Pentstemon................. & $\begin{array}{l}72 \\
72\end{array}$ & $\begin{array}{l}24 \text { to } 36 \text { in. } \\
18 \mathrm{in} . \\
12 \mathrm{in.}\end{array}$ & $\begin{array}{r}18 \\
9\end{array}$ & $\begin{array}{l}\text { White, pink, lavender, } \\
\text { crimson } \\
\text { (Leaves) purplish } \\
\text { White, pink, purple, }\end{array}$ \\
\hline 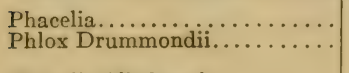 & $\begin{array}{l}73 \\
73\end{array}$ & $\begin{array}{l}9 \mathrm{in.} \\
6 \text { to } 18 \mathrm{in.}\end{array}$ & $\stackrel{8}{8}$ & $\begin{array}{l}\text { Blue } \\
\text { White, pink, scarlet, } \\
\text { lavender }\end{array}$ \\
\hline 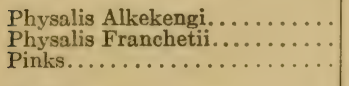 & $\begin{array}{l}75 \\
75 \\
75\end{array}$ & $\begin{array}{l}24 \text { in. } \\
24 \text { in. } \\
12 \text { in. }\end{array}$ & $\begin{array}{l}12 \\
12 \\
8 \text { to } 12\end{array}$ & $\begin{array}{l}\text { (Pods) orange } \\
\text { (Pods) red } \\
\text { Crimson, red, lilac, }\end{array}$ \\
\hline Portulaca........... & 77 & Creeping & 4 & Yellow, white, scarlet \\
\hline Rhodanthe.... & 101 & $12 \mathrm{in.}$ & 6 to 8 & Pink, white \\
\hline Salpiglossis.............. & $\begin{array}{l}78 \\
79 \\
79 \\
80 \\
\text { s0 }\end{array}$ & $\begin{array}{l}24 \text { in. } \\
24 \text { in. } \\
36 \text { in. } \\
6 \text { in. } \\
24 \text { to } 30 \text { in. }\end{array}$ & $\begin{array}{l}6 \\
12 \text { to } 18 \\
12 \text { to } 18 \\
8 \\
8\end{array}$ & $\begin{array}{l}\text { Crimson, gold, maroon } \\
\text { Blue } \\
\text { Scarlet } \\
\text { Yellow and purple } \\
\text { White, pink, scarlet, } \\
\text { blue, purple }\end{array}$ \\
\hline Schizanthus............. & $\begin{array}{r}81 \\
81 \\
101 \\
83\end{array}$ & $\begin{array}{l}24 \mathrm{in} . \\
8 \text { to } 36 \mathrm{in} . \\
30 \mathrm{in} . \\
12 \text { to } 18 \mathrm{in} .\end{array}$ & $\begin{array}{l}18 \\
12 \\
6 \text { to } 8 \\
12\end{array}$ & $\begin{array}{l}\text { Various } \\
\text { Various } \\
\text { Lavender, yellow } \\
\text { Tints of violet, pink, }\end{array}$ \\
\hline Summer Cypress......... & 81 & 24 to 30 in. & 24 & $\begin{array}{l}\text { White } \\
\text { (Foliage) turns from } \\
\text { green to bluish red }\end{array}$ \\
\hline 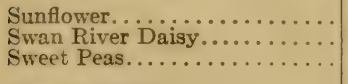 & $\begin{array}{l}84 \\
85 \\
86\end{array}$ & $\begin{array}{l}3 \text { to } 8 \mathrm{ft} . \\
10 \mathrm{in} . \\
36 \text { to } 72 \mathrm{in} .\end{array}$ & $\begin{array}{l}24 \\
5 \text { to } 6 \\
3 \text { to } 6\end{array}$ & $\begin{array}{l}\text { Orange, lemon } \\
\text { White, pink, blue } \\
\text { Various }\end{array}$ \\
\hline $\begin{array}{l}\text { Tagetes erecta.................... } \\
\text { Tagetes patula....... }\end{array}$ & $\begin{array}{l}61 \\
61\end{array}$ & $\begin{array}{l}30 \text { in. } \\
12 \text { in. }\end{array}$ & $\begin{array}{l}18 \\
18\end{array}$ & $\begin{array}{l}\text { Golden yellow } \\
\text { Golden yellow and } \\
\text { maroon }\end{array}$ \\
\hline 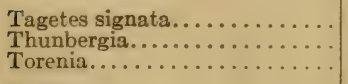 & $\begin{array}{r}62 \\
110 \\
92\end{array}$ & $\begin{array}{l}12 \mathrm{in.} \\
6 \mathrm{ft} . \\
12 \text { to } 15 \mathrm{in} .\end{array}$ & $\begin{array}{l}18 \\
6 \text { to } 8 \\
12 \text { to } 15\end{array}$ & $\begin{array}{l}\text { Golden yellow } \\
\text { Yellow, white, lemon } \\
\text { Blue, white }\end{array}$ \\
\hline $\begin{array}{l}\text { Verbena............ } \\
\text { Virginian Stock..... }\end{array}$ & $\begin{array}{l}92 \\
93\end{array}$ & $\begin{array}{l}12 \text { in. } \\
6 \text { to } 8 \text { in. }\end{array}$ & 12 & $\begin{array}{l}\text { Various } \\
\text { Lilac, red, white }\end{array}$ \\
\hline Xeranthemum.... & 102 & 36 in. & 8 & Purple, lavender, white \\
\hline Zea....... & 97 & 4 to $6 \mathrm{ft}$. & Clumps & $\begin{array}{l}\text { Ornamental grass; yel. } \\
\text { low, pink, and white } \\
\text { striped foliage } \\
\text { Various }\end{array}$ \\
\hline
\end{tabular}




\section{To Make This Book More Useful}

TO book can tell you all you should or want to know about such a 1 subject as gardening, nor even about a single phase of it such as the use of annuals. Full knowledge can come only from actual experience, observation, study and the application of the lessons to be learned from the living plants themselves, in addition to reading.'

To be of real help these facts and discoveries should be set down and kept for future reference. We have left the remaining pages in this volume blank so that upon them you can jot down notes about what you observe in your garden and other gardens; facts and data for ready reference; records of plant growth and cultural operations-so that each year's garden work will represent the mature judgment and accumulated wisdom of the seasons that have gone before. To the extent that you make use of these pages you will get from the rest of the book the helpful information and inspiration that it contains. 
Garden Notes and Memoranda 
Garden Notes and Memoranda 
Garden Notes and Memoranda 
Garden Notes and Memoranda 
Garden Notes and Memoranda 
Garden Notes and Memoranda 
Garden Notes and Memoranda 
Garden Notes and Memoranda 


\section{Garden Notes and Memoranda}


Garden Notes and Memoranda 
Garden Notes and Memoranda

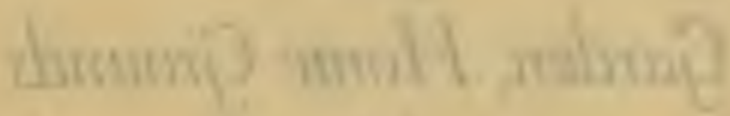
mond buok 


\section{BOOKS}

for the

\section{Garden, Home Grounds and Farm}

\section{SPECIALLY SELECTED TO MEET THE NEEDS OF ALL OWNING OR HOPING TO OWN HOMES IN THE COUNTRY OR SUBURBS}

Architecture in the Country-Houses, Bungalows, Barns, Garages, Garden Architecture.

The Garden-Flowers, Trees, Shrubs, Fruits, Vegetables, etc.

Landscape Gardening and Home Ground Surroundings. Agriculture, Farm and Domestic Animals, Poultry, Dairying and Dairy Products.

Fish, Frogs, Turtles, Snakes.

Bees, Birds, Butterflies, Insects.

Cultivation of Plants under Glass and in the Open. Soils, Fertilizers, Plant Diseases and Remedies, Insect Pests.

Indoor Games and Outdoor Sports, Boats, Autos and Airplanes, Camping.

Fiction Pertaining to Nature.

Descriptive catalog, listing the best books published in America on above subjects can be obtained from

A. T. DELAMARE COMPANY, Inc. 438 to 448 West 37 th St., NEW YORK, N. Y. 





\section{LIBRARY OF CONGRESS

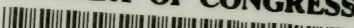

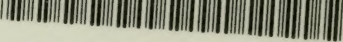 00009096425}

